Nat. Hazards Earth Syst. Sci. Discuss., doi:10.5194/nhess-2016-112, 2016

Manuscript under review for journal Nat. Hazards Earth Syst. Sci.

Published: 11 May 2016

(c) Author(s) 2016. CC-BY 3.0 License.

\title{
Research trends on hazards, disasters, risk reduction and climate change in Indonesia: a systematic literature review
}

Riyanti Djalante $e^{1,2}$

${ }^{1}$ Alexander von Humboldt Experienced Researcher Fellow / Research Associate, UNU-EHS, UN Campus, Platz der 5 Vereinten Nationen 1, Bonn 53117, Germany

${ }^{2}$ Honorary Lecturer, University of Halu Oleo, Sulawesi Tenggara, Indonesia

Correspondence to: Riyanti Djalante (djalante@ehs.unu.edu)

Abstract. The number of disasters due to natural hazards and climate change are on the rise. Within the last decade the world has experienced the most frequent and impactful disasters. The year 2015 was the hottest year ever and the associated disaster impacts have drastically increased the cost to the society socially and economically. The Asia Pacific region has been the place where these disasters occur the most. Indonesia, one of the countries in this region, is one of the most at risks from disasters and climate change impacts in this region.

This paper aims to do a systematic literature review on published academic materials related to hazards, risks, disaster risks reduction (DRR) and climate change in Indonesia. Systematic literature review is defined as systematic or evidence-based literature reviews with explicit and transparent methods and follows a standard protocol or a series of stages so that bias can be reduced and more importantly able to provide a comprehensive body of knowledge. While there is a vast material that have been published related to hazards and DRR on Indonesia, there has not yet a literature review that examines these materials in a comprehensive and systematic way. This systematic review is important since it outlines recent research progress over time which can help to determine which topics have been heavily researched and thus seeks to recommend future research needs. The author conducts a multi-staged literature review to study publications that are indexed within SCOPUS. Multi-stage processes are taken to determine inclusion and exclusion for more relevant findings. The author also consults authors' and organizations profiles from Google Scholar, Research Gate, to determine gender, affiliations, and extent of publications.

The first stage of search from Scopus gives a list of 5253 publications by which after second stage gives 1478 publications and third stage gives a final most relevant publication of 744 . The findings are outlined in two parts. One on the results of the analysis in terms of times of publications, most active researchers and research organizations, most cited papers, and categorization of major research topics. The other one is on the examinations on the roles of Indonesian authors and organizations in publishing in international journals, involvement in highly cited papers, and how collaborations have taken place amongst Indonesian and international researchers and organizations. This thus led to recommendations for capacity building in research in Indonesia.

The findings on the first part are as follow. The final selected publications are categorized into three major topics of (1) hazard, risks and disaster assessments (HRD), (2) disaster risk reduction (DRR), and (3) climate change vulnerability, impacts and adaptation (CC). Publications on the category of HRD are comprised of more than half of the total publications, while the rest is divided amongst those related to DRR and CC. The oldest publication was issued in 1978 and the earlier period publications were heavily focused on the topics of geophysical hazards and risks related to earthquake, volcanic activity and tsunami. There were a surge of publications following the 2004 Indian Ocean tsunami which impacted Aceh while publications related to DRR and CC increasingly gaining ground in the last 10 years. A more detailed analysis on research topics shows that on the HRD group is mainly related to research on volcanic eruption, tsunami and earthquake. Research on the DRR group focuses on governance, recovery and reconstruction, early warning systems. Those on CC groups, the research are mainly on reducing emissions from deforestation and forest degradation, governance of adaptation and climate change impacts on different sectors. 
Nat. Hazards Earth Syst. Sci. Discuss., doi:10.5194/nhess-2016-112, 2016

Manuscript under review for journal Nat. Hazards Earth Syst. Sci.

Published: 11 May 2016

(c) Author(s) 2016. CC-BY 3.0 License.

The findings on the role of Indonesian researchers and research organizations show great needs for capacity building in research, publications and collaborations. The study finds that international non-Indonesia authors dominate the number of researchers. Only half of the publications are co-authored by Indonesians. Collaborations have indeed taken place amongst between international and Indonesian organizations but it is only by limited number of Indonesian organizations or researchers. This suggest that Indonesians researchers tend to work with other Indonesians and hence needed to expand their collaborations with international scholars as a strategy to increase the quality of the publications measured by the number of citations and ability to submit for higher impact journals.

The paper recommends further research to be done on research on hazards and risks identifications on other locations in Indonesia, preparedness and on vulnerable groups, and governance and impacts of climate change on different sectors. It also calls for more strengthening capacity of Indonesian authors in writing for international journal publications and creating space for collaborations amongst Indonesian and international researchers.

Acknowledgement. The author would like to express its gratitude to the Alexander von Humboldt Foundation through its Fellowships for Experienced Researcher, which has enabled the author to conduct a research visit for 18 months in Germany. The author would also like to thanks Dr Matthias Garschagen for his earlier review of the manuscript. This paper reflects to author own view and not representing any organization.

Keywords. Systematic literature review; Indonesia; disaster; natural hazard; climate change

\section{Introduction}

Disaster events and their associated social and economical impacts are on the rise. The last decade has shown the highest number and impacts from disasters while 2015 has been stated as the hottest year ever. The Asia Pacific region has been the place where these disasters occur most while Indonesia is one of the most at risks from disasters and climate change impacts (Figure 1).

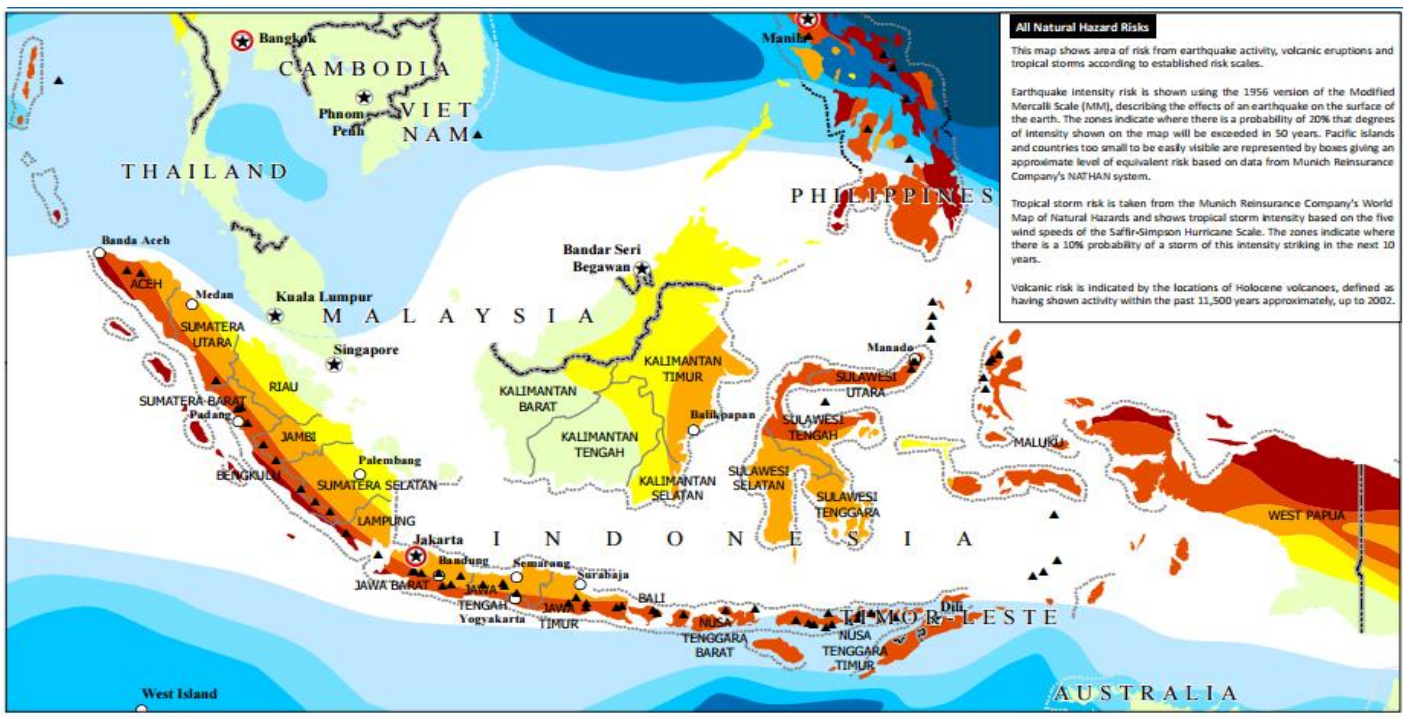

Figure 1 Hazard map of Indonesia (OCHA-ROAP 2011)

Over the last century, there have been 429 disasters caused by natural hazards, more than 200 thousands death, more than 29 million people in total affected and the total damage is above 44million USD (Table 1) (EMDAT, 2016). 
Nat. Hazards Earth Syst. Sci. Discuss., doi:10.5194/nhess-2016-112, 2016

Manuscript under review for journal Nat. Hazards Earth Syst. Sci.

Published: 11 May 2016

(c) Author(s) 2016. CC-BY 3.0 License.

Table 1 Disaster impacts in Indonesia from 1900 - 2016 (EMDAT, 2016)

\begin{tabular}{|llllllll|}
\hline Disaster type & $\begin{array}{l}\text { Occurrenc } \\
\text { e }\end{array}$ & $\begin{array}{l}\text { Total } \\
\text { deaths }\end{array}$ & Affected & Injured & Homeless & $\begin{array}{l}\text { Total } \\
\text { affected }\end{array}$ & $\begin{array}{l}\text { Total damage } \\
\text { (USD) }\end{array}$ \\
\hline Earthquake & 115 & 198487 & 7401192 & 171429 & 1556548 & 9129169 & 11695926 \\
\hline Volcanic activity & 56 & 18310 & 1294297 & 3731 & 23500 & 1321528 & 530390 \\
\hline Drought & 10 & 9340 & 4804220 & 0 & 0 & 4804220 & 160200 \\
\hline Flood & 172 & 6555 & 9445598 & 255197 & 183295 & 9884090 & 6422047 \\
\hline Landslide & 53 & 2423 & 356696 & 540 & 40015 & 397251 & 120745 \\
\hline $\begin{array}{l}\text { Mass movement } \\
\text { dry) }\end{array}$ & 1 & 131 & 651 & 50 & 0 & 701 & 1000 \\
\hline Storm & 12 & 2013 & 28715 & 243 & 1290 & 30248 & 1000 \\
\hline Wildfire & 10 & 319 & 3443664 & 478 & 0 & 3444142 & 25429000 \\
\hline Total & 429 & 237,578 & $26,775,033$ & 431,668 & $1,804,648$ & $29,011,349$ & $44,360,308$ \\
\hline
\end{tabular}

Furthermore, when comparing the impacts between geophysical and those hydro-meteor-climato-logical disasters, while disasters caused by climate occurs and impacts more, the number of deaths is significantly caused by earthquake and volcanic activities (Figure 2). Hence, it is important to differentiate the hazard types but also to integrated risks management from both types in an integrated fashion (e.g. Djalante and Thomalla, 2012; Thomalla et al., 2006).

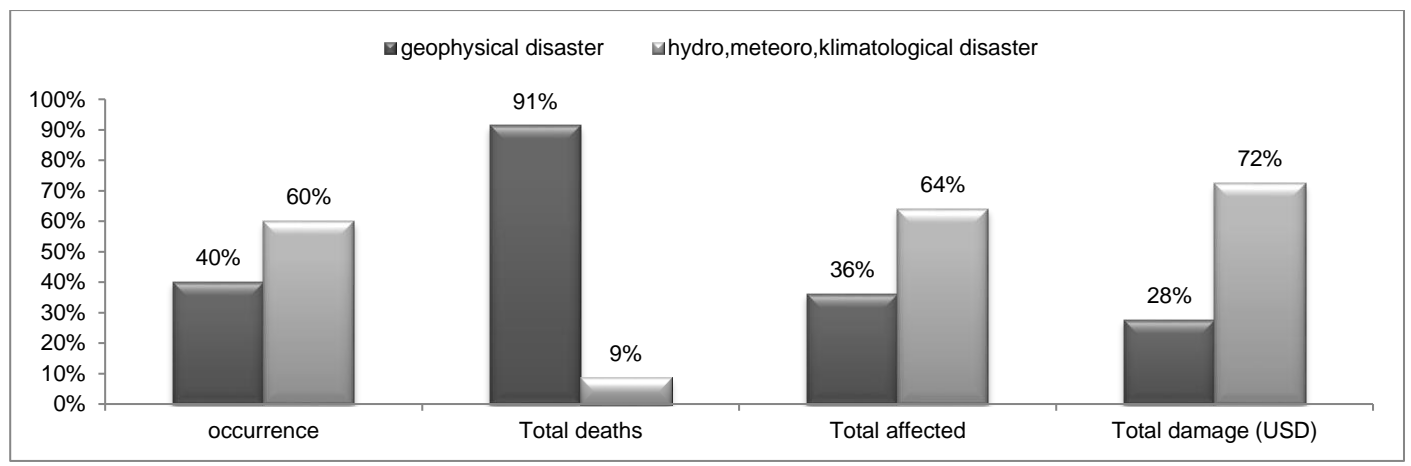

Figure 2 Comparing between the impacts of geophysical and hydro-meteoro-klimatological disasters (modified from EMDAT, 2016)

80 This paper aims to systematically review literature on related to hazards, risks and disaster risks reduction, and climate change vulnerability, impact, and assessments in Indonesia. Systematic literature review is briefly defined as a method to systematically reviewing evidence or literature with explicit and transparent methods. A systematic review method has been used widely in the field of health (Moher et al., 2009), software engineering (Kitchenham et al., 2009), and engineering (Carrion and Levinson, 2012; Chai et al., 2013; Gosling and Naim, 2009; Liang et al., 2009). Despite the importance of systematic literature review, there have been few studies that use this in the topic related to hazards, disasters, and or climate change. Some notable examples are review on drought (Woodhouse and Overpeck, 1998), landslide (Aleotti and Chowdhury, 1999), contaminants (Noyes et al., 2009), urban ecosystem (Luederitz et al., 2015), ecosystem-based adaptation (Brink et al., 2016; Kabisch et al., 2015). A notable study on systematic review of climate change is done by Berrang-Ford et al (Berrang-Ford et al., 2014; Berrang-Ford et al., 2011; Berrang-Ford et al., 2015; Ford et al., 2015a; Ford et al., 2015b; Ford et al., 2013; Ford et al., 2011; Ford et al., 2012; Lesnikowski et al., 2013a; Lesnikowski et al., 2013b; McLeman et al., 2014; Paterson et al., 2012; Pearce et al., 2011; Thompson et al., 2010). 
Nat. Hazards Earth Syst. Sci. Discuss., doi:10.5194/nhess-2016-112, 2016

Manuscript under review for journal Nat. Hazards Earth Syst. Sci.

Published: 11 May 2016

(c) Author(s) 2016. CC-BY 3.0 License.

Even though there is a vast material that have been published related to this topic on Indonesia, there has not yet a literature review that examines these materials in a comprehensive and systematic way. By reviewing published works in this fashion, researchers can build upon others' works and avoid reinventing the wheel so that not only determining which areas and topics that have been heavily researched, but also which further areas that needed more researches. There are two research questions adopted. First is on progress of research on hazards, risks, disasters and climate change in Indonesia, and when, how and who have been involved in those research and publications. Second is on roles of Indonesian authors in contributing for research, publishing in international journals, involvement in highly cited papers, and collaborations amongst Indonesian and international researchers and organizations. The key argument of this paper is that while there are limited number of Indonesian authors who and research organizations that have collaborated and published globally, in general, Indonesian authors have lower level of involvement in international collaboration and publications in high quality and high impact publications. Based on their extensive review on climate change literature, Berrang-Ford et al (2011; 2015) suggested an analytical approach for systematic review and research synthesis as presented in Table 2, which is adopted in this paper.

Table 2 Analytical approach for the systematic review

\begin{tabular}{|lll|}
\hline Topics & & Descriptions \\
\hline Research questions and aim & $\cdot$ & Explicit \\
\hline Data sources and document selection & $\cdot$ & Clear description \\
& $\cdot$ & Justification and description of sources \\
& $\cdot$ & Articulation of search term \\
& $\cdot$ & Description of inclusion and exclusion \\
\hline Analysis and presentation of results & $\cdot$ & Documentation of literature included and excluded \\
& $\cdot$ & Description of method for analysis \\
\hline
\end{tabular}

The structured of the paper follows the above analytical approach. The first section of this paper outlines the rationale, aim and research questions adopted. The second section outlines research method related to data sources and document selection. The third section gives the analysis and presentation of results, and the last section describes the conclusion and recommendations for further research.

\section{Research method: data sources and document selection}

\subsection{Justification and description of sources}

115 The author conducts a multi-layered literature review to study publications using the Scopus research engine. There have been several studies comparing strengths and weakness of PubMed, Scopus, Web of Science and Google Scholar (Bakkalbasi et al., 2006; Bar-Ilan, 2008; Falagas et al., 2008; Kulkarni et al., 2009). Scopus research engine is selected because it is the largest abstract and database of peer-review literature (Burnham, 2006; De Moya-Anegón et al., 2007; Leydesdorff et al., 2010). Additional information is gathered from Google Scholar (Google, 2016), Research Gate (Gate,

120 2016) or researchers' profiles to give the full extent of particular scholars' works. The author checks the organizations, nationalities and genders of the researchers in the Internet through Google. Multi-staged processes are taken to determine inclusion and exclusion for more relevant findings.

\subsection{Articulation of search term and description and documentation of inclusion and exclusion}

\section{First stage}


Nat. Hazards Earth Syst. Sci. Discuss., doi:10.5194/nhess-2016-112, 2016

Manuscript under review for journal Nat. Hazards Earth Syst. Sci.

Published: 11 May 2016

(c) Author(s) 2016. CC-BY 3.0 License.

The author input the following search terms into SCOPUS which gives a total hit of 5253 publications, (TITLE-ABSKEY(hazard*) OR TITLE-ABS-KEY(risk*) OR TITLE-ABS-KEY(disaster*) OR TITLE-ABS-KEY(disaster management*) OR TITLE-ABS-KEY(disaster risk reduction*) OR TITLE-ABS-KEY(climate change*) OR TITLE-ABSKEY(climate change adaptation*) OR TITLE-ABS-KEY(resilien*) AND TITLE-ABS-KEY(Indonesia)).

\section{Second stage}

130 The author applies the second stage to further refine the results. This gives a total hit of 1748 publications. The exclusion includes refinement in subject areas, in document types, in language (only in English and Bahasa Indonesia), and source title that does not directly related to the topic in DRR in Indonesia.

\section{Third stage}

The third layer search involve the author download the results into xml format, save it and import it into Microsoft Excel, with using all delimiters factors. The results in the Excel format are examined line by line to further determine exclusion from the lists. Materials that are excluded in this final round is related to analysis of research in mining industry in Indonesia, those that discuss on the science of climate change and those that touch on the issue on disasters but not directly on Indonesia and when the author judges that the scope is too broad to be included are finally 744 materials selected. The final list is analyzed in terms of authorships, references, citations, keywords, places of focus, types of publications, impact factors, time of publications and topics and sub-topics of research. Table 3 shows the EMDAT-CRED categorization of disaster groups and hazards that are used in this study to help more details analysis related to major research topics. Natural disaster groups caused by geophysical, meteorological, hydrological, and climatologically hazards are included. Those excluded are disasters caused by biological, extra-terrestrial and technological hazard.

Table 3 Categorization of disaster groups included in this study (Source: EMDAT-CRED, 2016)

\begin{tabular}{|c|c|c|c|c|}
\hline $\begin{array}{l}\text { Disaster } \\
\text { Group }\end{array}$ & $\begin{array}{l}\text { Disaster } \\
\text { Subgroup }\end{array}$ & Definition & $\begin{array}{l}\text { Disaster Main } \\
\text { Type }\end{array}$ & Disaster Sub-Sub-Type \\
\hline \multirow[t]{12}{*}{ Natural } & \multirow[t]{3}{*}{ Geophysical } & \multirow{3}{*}{$\begin{array}{l}\text { A hazard originating from solid } \\
\text { earth. This term is used } \\
\text { interchangeably with the term } \\
\text { geological hazard. }\end{array}$} & Earthquake & Ground shaking, tsunami \\
\hline & & & $\begin{array}{l}\text { Mass } \\
\text { Movement }\end{array}$ & \\
\hline & & & $\begin{array}{l}\text { Volcanic } \\
\text { activity }\end{array}$ & $\begin{array}{l}\text { Ash fall, lahar, Pyroclastic } \\
\text { flow, Lava flow }\end{array}$ \\
\hline & \multirow[t]{3}{*}{ Meteorological } & \multirow{3}{*}{$\begin{array}{l}\text { A hazard caused by short-lived, } \\
\text { micro- to meso-scale extreme } \\
\text { weather and atmospheric } \\
\text { conditions that last from minutes to } \\
\text { days. }\end{array}$} & $\begin{array}{l}\text { Extreme } \\
\text { Temperature }\end{array}$ & $\begin{array}{l}\text { Cold wave, heat wave, } \\
\text { severe winter conditions }\end{array}$ \\
\hline & & & Fog & \\
\hline & & & Storm & $\begin{array}{l}\text { Extra-tropical storm, } \\
\text { Tropical storm, Convective } \\
\text { Storm (Derecho, Hail, } \\
\text { Lightning/thunderstorm, } \\
\text { Rain, Tornado, Sand/dust } \\
\text { storm, Winter } \\
\text { storm/blizzard, Storm/surge, } \\
\text { Wind) }\end{array}$ \\
\hline & \multirow[t]{3}{*}{ Hydrological } & \multirow[t]{3}{*}{$\begin{array}{l}\text { A hazard caused by the } \\
\text { occurrence, movement, and } \\
\text { distribution of surface and } \\
\text { subsurface freshwater and } \\
\text { saltwater. }\end{array}$} & Flood & $\begin{array}{l}\text { Coastal flood } \\
\text { Riverine flood } \\
\text { Flash flood } \\
\text { Ice jam flood }\end{array}$ \\
\hline & & & Landslide & $\begin{array}{l}\text { Avalanche (snow, debris, } \\
\text { mudflow, rockfall) }\end{array}$ \\
\hline & & & Wave action & Rogue wave, seiche \\
\hline & \multirow[t]{3}{*}{ Climatological } & \multirow{3}{*}{$\begin{array}{l}\text { A hazard caused by long-lived, } \\
\text { meso- to macro-scale atmospheric } \\
\text { processes ranging from intra- } \\
\text { seasonal to multi-decadal climate } \\
\text { variability. }\end{array}$} & Drought & \\
\hline & & & $\begin{array}{l}\text { Glacial Lake } \\
\text { Outburst }\end{array}$ & \\
\hline & & & Wildfire & \\
\hline
\end{tabular}


Nat. Hazards Earth Syst. Sci. Discuss., doi:10.5194/nhess-2016-112, 2016

Manuscript under review for journal Nat. Hazards Earth Syst. Sci.

Published: 11 May 2016

(c) Author(s) 2016. CC-BY 3.0 License.

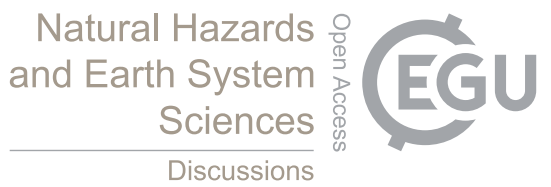

\subsection{Critical appraisal of information quality}

After the second stage is done, the author downloads to material into xml format and later imports it into the Microsoft Excel format. When importing into the excel format the author choose all delimiters to enable particular information goes to the right column. However, the results are not always consistent and hence a manual check on each entry row needed to be done. Data from Scopus is used to determine which of the publication is highly cited, who are the most active authors and organizations, where they are based and what keywords are used. However the author finds that the number counts on the authors' publications and citations presented in the SCOPUS search is sometimes different to the actual check of the excel sheet. It is also different when examining the profile of one particular author. Hence, to ensure consistency, the number of counts obtained from the list in excel sheet is used.

155 Moreover, the author crosschecks the number of citations from Scopus to the Internet, and adopts the higher citation counts. It is generally the case that data from Google search on the publication and author leads to higher and more up to date citations counts. The author also consult total citations and publications of researchers in Google Scholar or Research Gate or Researcher other profile to make sure that the full list of publications are captured.

\section{$3 \quad$ Analysis and Presentation of Results}

160 This section is structured based on the research questions on the analysis of the materials and second on the roles of Indonesian authors and organizations. Materials gathered are analyzed in terms of time, active researchers, research organizations, most cited papers, and categorized into several main research topics. In each of main research topics, the analysis differentiates the roles of international and Indonesian researchers and research organizations.

\subsection{Review of key research topics}

\subsubsection{Groupings of topics}

The author categorizes the final list into three groups in order to show and outline how changes in directions on research have taken place over the years and to reduce heavy unbalance towards findings on hazard and risks assessments toward earthquake and volcanic eruption research (Table 4).

Table 4 Classifications of findings based on topics of research

\begin{tabular}{|ll|}
\hline Major topics groups & Relevant Definitions (UNISDR, 2009) \\
\hline $\begin{array}{l}\text { (1) hazard, risks, } \\
\text { disasters assessments } \\
\text { (HRD) }\end{array}$ & $\begin{array}{l}\text {-Hazards: A dangerous phenomenon, substance, human activity or condition that may cause loss of life, } \\
\text { injury or other health impacts, property damage, loss of livelihoods and services, social and economic } \\
\text { disruption, or environmental damage. } \\
\text {-Risks: The combination of the probability of an event and its negative consequences. } \\
\text {-Disaster: A serious disruption of the functioning of a community or a society involving widespread } \\
\text { human, material, economic or environmental losses and impacts, which exceeds the ability of the affected } \\
\text { community or society to cope using its own resources. }\end{array}$ \\
\hline $\begin{array}{l}\text { (2) disaster risk } \\
\text { management or } \\
\text { reduction (DRR) }\end{array}$ & $\begin{array}{l}\text { - The systematic process of using administrative directives, organizations, and operational skills and } \\
\text { capacities to implement strategies, policies and improved coping capacities in order to lessen the adverse } \\
\text { impacts of hazards and the possibility of disaster (UNISDR). }\end{array}$ \\
$\begin{array}{l}\text { - The concept and practice of reducing disaster risks through systematic efforts to analyze and manage the } \\
\text { causal factors of disasters, including through reduced exposure to hazards, lessened vulnerability of } \\
\text { people and property, wise management of land and the environment, and improved preparedness for }\end{array}$ \\
adverse events.
\end{tabular}


Nat. Hazards Earth Syst. Sci. Discuss., doi:10.5194/nhess-2016-112, 2016

Manuscript under review for journal Nat. Hazards Earth Syst. Sci.

Published: 11 May 2016

(c) Author(s) 2016. CC-BY 3.0 License.

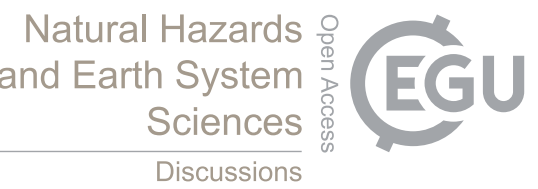

(c) (i)

\subsubsection{Yearly assessments}

There are several periods of development in the publications, which are thought to be corresponded to the occurrence on major hazards or disasters events in Indonesia (Figure 4).

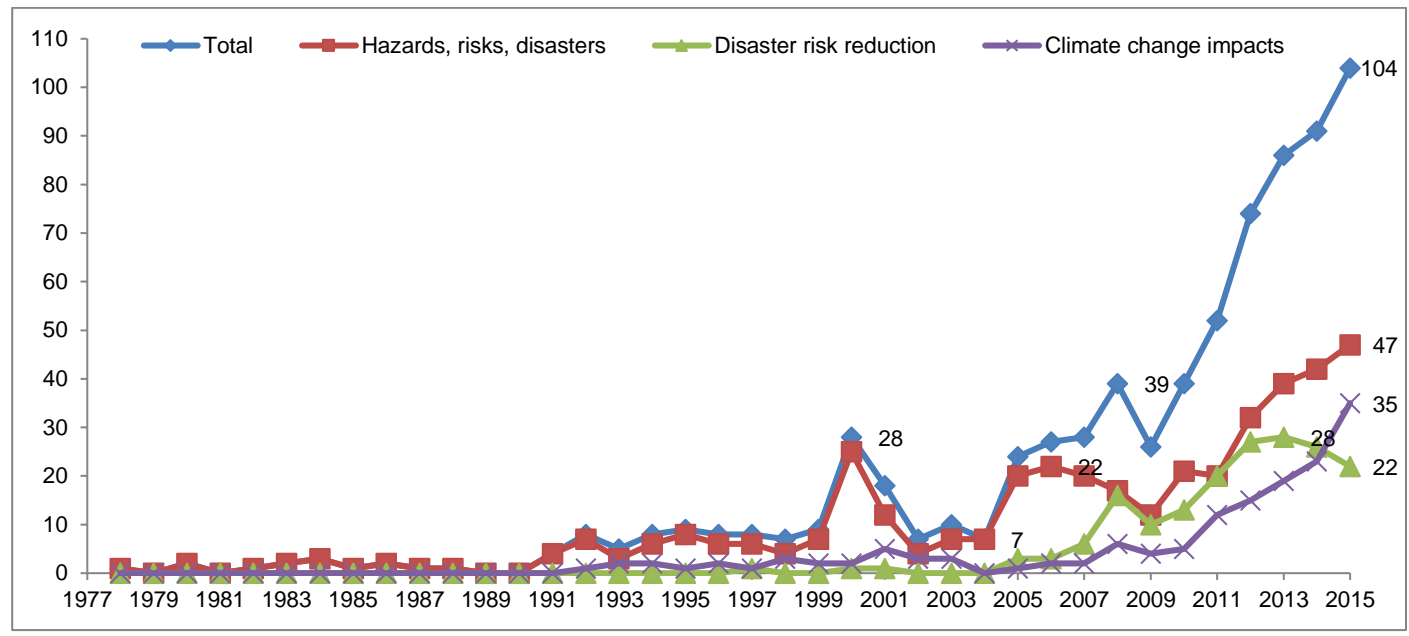

Figure 3 Number of publications over the year (total 744)

The first period is within the 1970s-1980s period. In this period, there were no significant changes in the numbers of publications produced. Researches in this period were heavily done on the topics of geophysical hazards and risks related to

earthquake and volcanic eruption. The second period 1990s to 2000s shows a notable increase in literature where on average there were 10 publications per year. This gradual increase in literature mainly corresponds to the literature related to the assessments of hazards, risks and disasters and there is a sharp increase in literature which reached its highest point in 2000. The third period of 2000-2010s was the most dynamic period within the publications on literature. While there was a sharp decline since it reached its first peak in 2000, a surge of publications was started in 2004 which correspond to the Indian Ocean tsunami which hit Indonesia the most. This increase continues ever since. This is also the period when not only publications related to understanding the risks of earthquake and tsunami, but also those related to examining DRR and climate change impacts. The peak occurs between 2010 and 2015 which shows soaring published materials in all topics. There are 104 publications in 2015 which is the highest ever produced in a single year. In this period, publications related to climate change and their impact on Indonesia has started to be considered and is expected to still increase in the future.

190 While both publications on hazards group and climate change group are expected to rise, the publications on the DRR shows a trend of decline.

\subsubsection{Number of publications, citations, keywords and locations of research}

As can be seen from Table 5, publications in the research topic related to hazards, risks, and disasters outweigh the other two categories. There are more than half materials are written on the topic of hazards, risks and disasters, and the rest is divided almost equally between those on DRR and climate change. The hazards, risks and disasters category also have the highest total numbers of citations, and have more than two third of the citations. An examination on the citation average however show a quite different story, while the climate change literature category has the least number of papers published, the citation average reach 8.0, which is similar to that of the hazard, risk and disaster category (Figure 4). 
Nat. Hazards Earth Syst. Sci. Discuss., doi:10.5194/nhess-2016-112, 2016

Manuscript under review for journal Nat. Hazards Earth Syst. Sci.

Published: 11 May 2016

(c) Author(s) 2016. CC-BY 3.0 License.
Natural Hazards

and Earth System

Sciences

Discussions

(c) (i)

Table 5 Total numbers of papers, citations and citation average

\begin{tabular}{|lllll|}
\hline \multicolumn{2}{|l}{ Main research topics } & Numbers of papers & Numbers of citations & Citation average \\
\hline $\begin{array}{l}\text { Hazards, risks, disasters } \\
\text { (HRD) }\end{array}$ & 412 & 3386 & 8.0 \\
\hline $\begin{array}{l}\text { Disaster } \\
\text { (DRR) }\end{array}$ & risk reduction & 177 & 668 & 3.8 \\
\hline Climate change (CC) & 154 & 1237 & 8.0 \\
\hline \hline Total & $\mathbf{7 4 4}$ & $\mathbf{5 2 9 1}$ & - \\
\hline
\end{tabular}

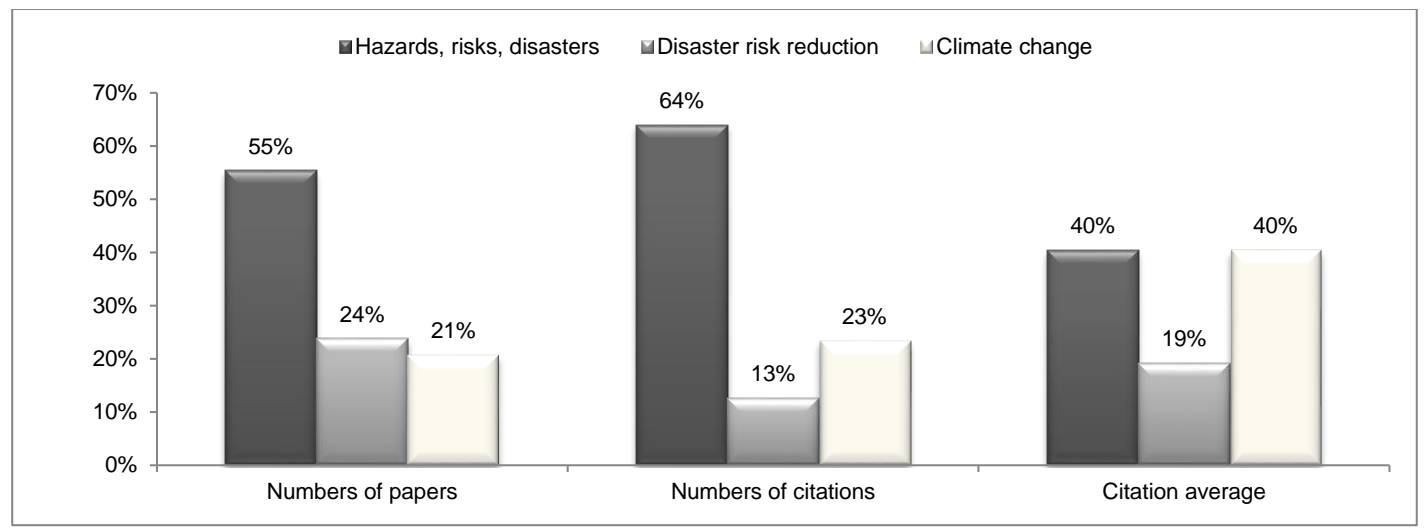

Figure 4 Comparing publications in 3 categories in terms of numbers of papers, numbers of citations, and citation average per paper (total 744)

A more detailed examinations on the keywords used are mostly related to place followed by those related to hazards, and risks and disasters (Figure 5). If we look at the locations within Indonesia, the region of Java and Sumatera are the most research locations (Figure 6). This is understandable since both islands are the most at risks from geophysical hazards.

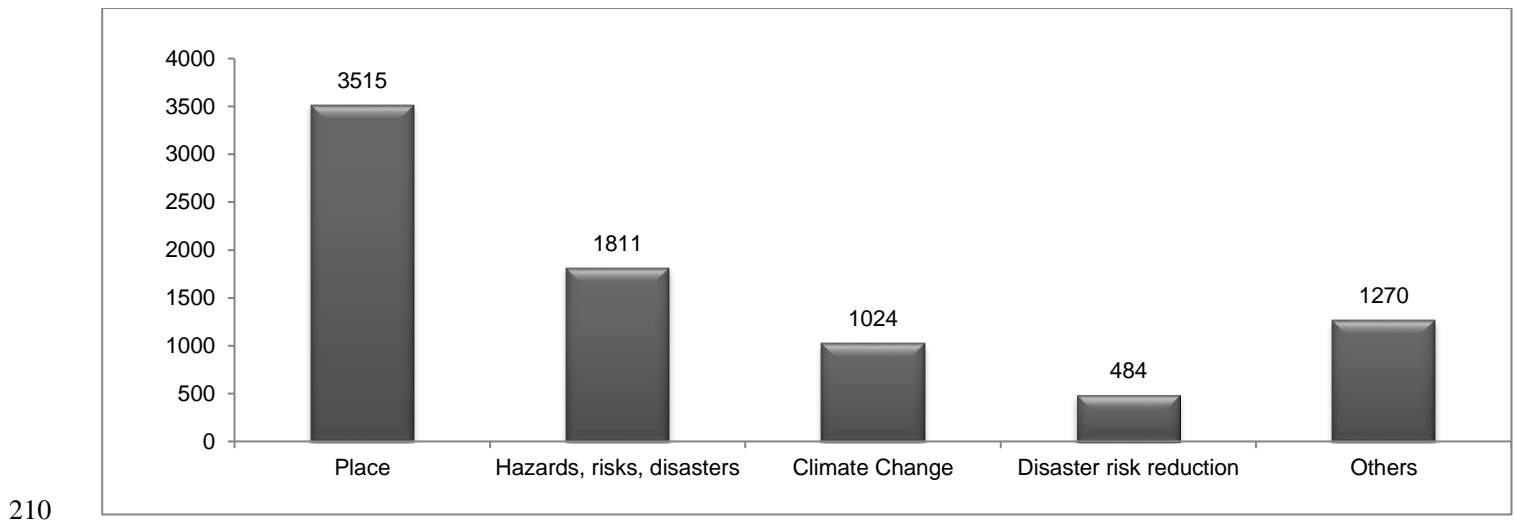

Figure 5 categorization of keywords used 
Nat. Hazards Earth Syst. Sci. Discuss., doi:10.5194/nhess-2016-112, 2016

Manuscript under review for journal Nat. Hazards Earth Syst. Sci.

Published: 11 May 2016

(c) Author(s) 2016. CC-BY 3.0 License.

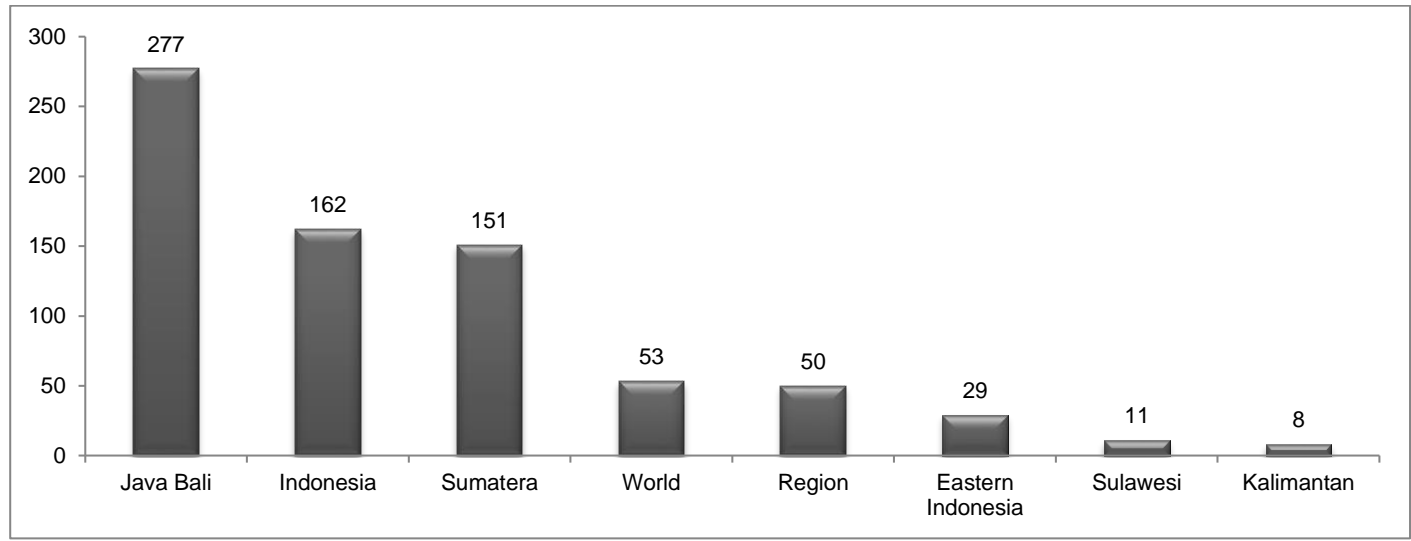

Figure 6 Locations by which the researches are focused on (total 744)

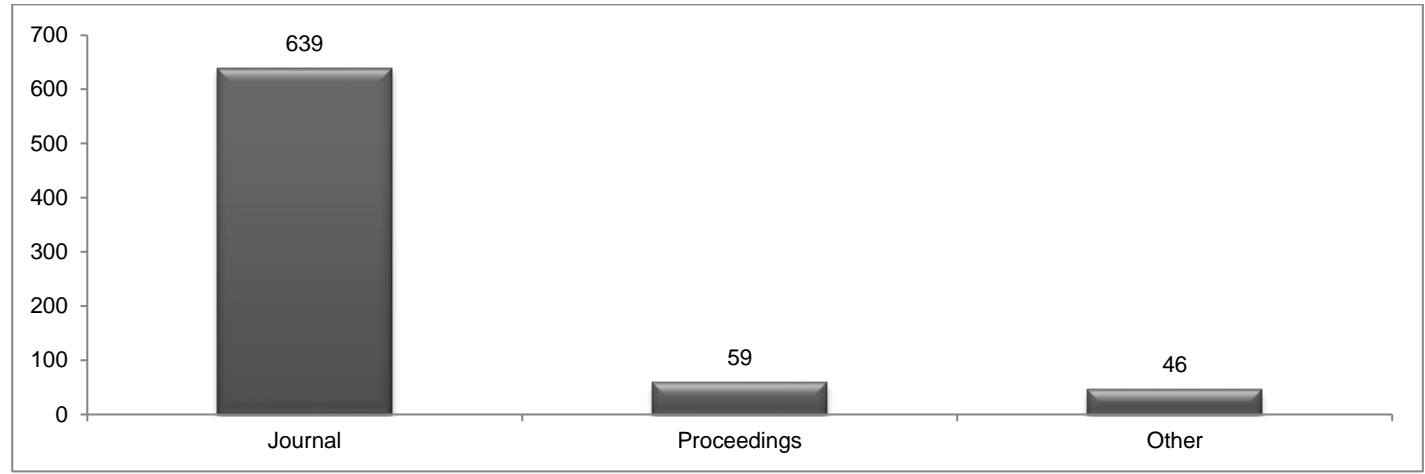

Figure 7 Publications types (total 744)

Table 6 List of most frequent journals

\begin{tabular}{|c|c|c|c|c|c|}
\hline \multirow[t]{2}{*}{ Publications } & \multirow{2}{*}{$\begin{array}{l}\text { Number } \\
\text { of papers }\end{array}$} & \multirow[t]{2}{*}{ IF / SJR } & \multicolumn{3}{|c|}{ Category } \\
\hline & & & HRD & DRR & $\mathrm{CC}$ \\
\hline Journal of Volcanology and Geothermal Research & 75 & 2.543 & $\mathrm{x}$ & & \\
\hline Natural Hazards and Earth System Science & 27 & 1.735 & $\mathrm{x}$ & $\mathrm{x}$ & \\
\hline Bulletin of Volcanology & 22 & 2.519 & $\mathrm{x}$ & & \\
\hline Earth and Planetary Science Letters & 16 & 4.734 & $\mathrm{x}$ & & \\
\hline Pure and Applied Geophysics & 15 & 1.618 & $\mathrm{x}$ & & \\
\hline Nature & 14 & 41.456 & $\mathrm{x}$ & & $\mathrm{x}$ \\
\hline Journal of Disaster Research & 14 & SJR 0.18 & & $\mathrm{x}$ & \\
\hline
\end{tabular}


Nat. Hazards Earth Syst. Sci. Discuss., doi:10.5194/nhess-2016-112, 2016

Manuscript under review for journal Nat. Hazards Earth Syst. Sci.

Published: 11 May 2016

(c) Author(s) 2016. CC-BY 3.0 License.

\begin{tabular}{|c|c|c|c|c|c|}
\hline \multirow[t]{2}{*}{ Publications } & \multirow{2}{*}{$\begin{array}{l}\text { Number } \\
\text { of papers }\end{array}$} & \multirow[t]{2}{*}{$\mathrm{IF} / \mathrm{SJR}$} & \multicolumn{3}{|c|}{ Category } \\
\hline & & & HRD & DRR & $\mathrm{CC}$ \\
\hline Journal of Geophysical Research: Solid Earth & 12 & 3.426 & $\mathrm{x}$ & & \\
\hline $\begin{array}{l}\text { Bulletin of the International Institute of Seismology and Earthquake } \\
\text { Engineering }\end{array}$ & 12 & SJR 0.12 & $\mathrm{x}$ & & \\
\hline Disasters & 10 & 0.742 & & & \\
\hline International Journal of Remote Sensing & 9 & 1.652 & $\mathrm{x}$ & & \\
\hline Bulletin of the Seismological Society of America & 7 & 2.322 & $\mathrm{x}$ & & \\
\hline
\end{tabular}

A very striking Figure, however, is shown when comparing the number of Indonesian journals that got indexed in SCOPUS as shown in Table 7. The Indonesian Journal of Geography is the only Indonesian journal included in the search with 7 papers listed. The journal was established in 1961 by the Faculty of Geography, of Gadjah Mada University, in cooperation with the Association of the Indonesian Geographers. The director of the editorial board is Sudibyakto, with Sartohadi,

230 Lavigne and Marfai as members of the editorial board (UGM, 2016). There are no clear counts on the number of academic journals in Indonesia, however, there are only 245 are accredited by DIKTI (Higher education directorates of the Ministry of Education) (DIKTI, 2016a) and 17 indexed in SCOPUS (DIKTI, 2016b). There are also none of these journals that have obtained an impact factor yet, and hence a Scientific Journal Ranking (SJR) Score is presented (SJR, 2016).

Table 7 List of Indonesian Journals that are indexed with SCOPUS

\begin{tabular}{|lll|}
\hline Rank Title & \multicolumn{2}{c|}{ SJR } \\
\hline $\mathbf{1}$ Nutrition Bulletin & 0,267 & 25 \\
\hline $\mathbf{2}$ Bulletin of Chemical Reaction Engineering and Catalysis & 0,251 & 5 \\
\hline $\mathbf{3}$ Acta medica Indonesiana & 0,239 & 12 \\
\hline $\mathbf{4}$ Telkomnika & 0,236 & 6 \\
\hline $\mathbf{5}$ International Journal on Electrical Engineering and Informatics & 0,2 & 7 \\
\hline $\mathbf{6}$ Indonesian Journal of Chemistry & 0,175 & 2 \\
\hline $\mathbf{7}$ International Journal of Power Electronics and Drive Systems & 0,157 & 4 \\
\hline $\mathbf{8}$ Kukila & 0,152 & 2 \\
\hline $\mathbf{9}$ Journal of Engineering and Technological Sciences & 0,123 & 3 \\
\hline $\mathbf{1}$ Gadjah Mada International Journal of Business & 0,12 & 1 \\
\hline $\mathbf{1}$ Critical Care and Shock & 0,115 & 7 \\
\hline $\mathbf{1}$ International Journal of Technology & 0,115 & 2 \\
\hline $\mathbf{1}$ Journal of Mathematical and Fundamental Sciences & 0,112 & 4 \\
\hline $\mathbf{1}$ Journal of ICT Research and Applications & 0,106 & 2 \\
\hline $\mathbf{1}$ Biotropia & 0,103 & 1 \\
\hline $\mathbf{1}$ Indonesian Journal of Geography & 0,101 & 1 \\
\hline $\mathbf{1}$ Agrivita & & \\
\hline
\end{tabular}

\subsubsection{Key research topics}

This section presents the more detailed findings of each of the three research topics. 
Nat. Hazards Earth Syst. Sci. Discuss., doi:10.5194/nhess-2016-112, 2016

Manuscript under review for journal Nat. Hazards Earth Syst. Sci.

Published: 11 May 2016

(c) Author(s) 2016. CC-BY 3.0 License.

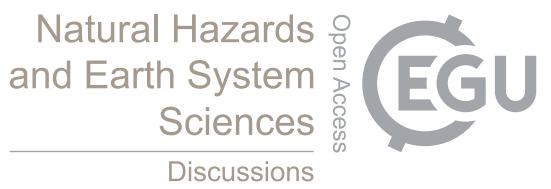

(c) (i)

\subsubsection{Topics on hazards, risks and disasters assessments}

The first sub-section explains the timelines, contents of researcher and locations inquired within or outside Indonesia on the topic of hazards, risks and disasters assessments and identifications. As can be seen from Figure 8, there has been a gradual increase on the number of published materials since 1978 to 1998. It is only in 2000 that the research in this topic reached its first significant outputs of 25 publications. The next 4 years showed a sharp reduction in the number of publication. In 2004 the Indian Ocean tsunami occurred and hit Indonesian the most. Publications related the tsunami continued to be published until it reached its peak in 2006. Then in 2009, the publications started to increase rapidly ever since and reached its peak in 2015 of 47 publications in a single year.

Most of the literature around this period focuses on the impacts of volcanic eruptions in Java and Sumatera. The oldest publications related to hazards in Indonesia listed in Scopus are those by Neall (1976), Lahars as major geological Hazards published in the Bulletin of the International Association of Engineering Geology, and one by Nakamura (1978) on the Statistics of tsunamis in Indonesia in the Southeast Asian Studies. In terms of contributions by Indonesia researchers, the earliest papers are by Sudradjat and Tilling (1984) on the Volcanic hazards in Indonesia: the 1982-83 eruption of Galunggung, and Suryo and Clarke (1985) on the occurrence and mitigation of volcanic hazards in Indonesia as exemplified at the Mount Merapi, Mount Kelud and Mount Galunggung volcanoes in the Quarterly Journal of Engineering Geology.

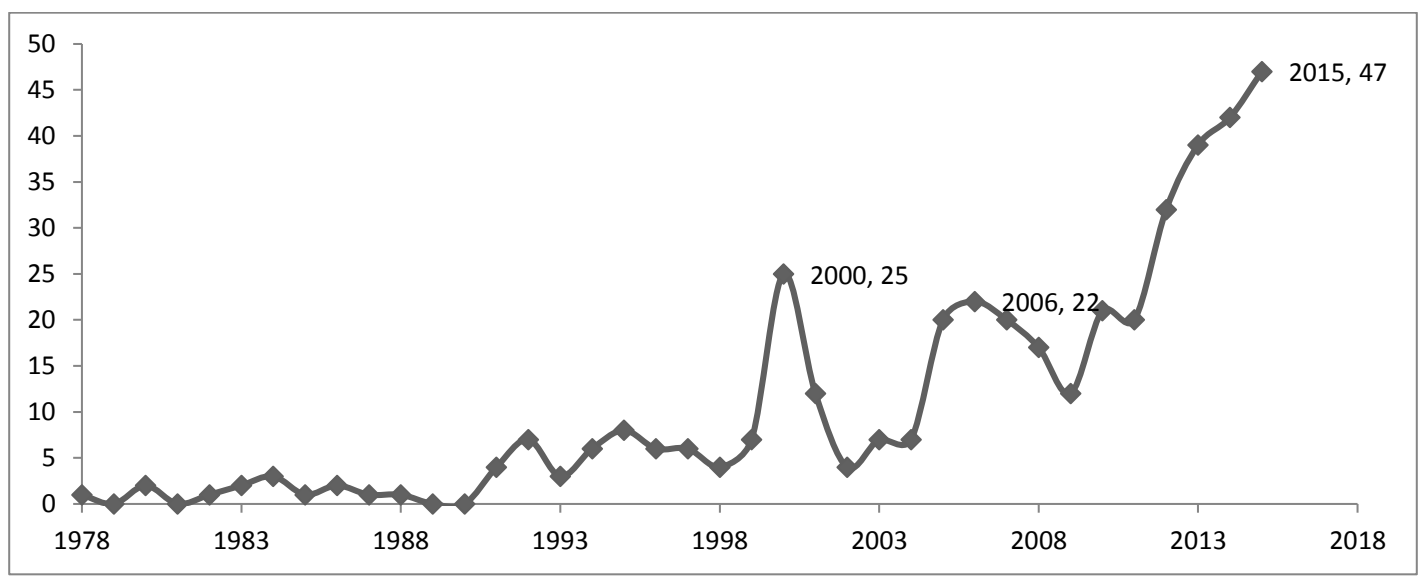

Figure 8 Number of publications on hazards, risks, and disasters over the year (total 413)

Utilizing the definition provided by EMDAT-CRED on the classifications of geophysical hazards, the study finds that there are the majority of publications are related to volcanic eruption, dominated by the study of volcanoes in Java such as Merapi (Andreastuti et al., 2000; Charbonnier and Gertisser, 2008; Gertisser et al., 2012; Lavigne, 1999; Verstappen, 1988; Voight et al., 2000), Semeru (Carn, 1999; Siswowidjoyo et al., 1997; Solikhin et al., 2012; Thouret et al., 2007), Kelud (Lubis, 2014; Nakada et al., 2016)or Ijen (Heikens et al., 2005; Trunk and Bernard, 2008; van Hinsberg et al., 2010) (Figure 9). The other hazard that receives many studies is related to examination of earthquake, how it happened, and methods to assess the impacts. The research on tsunami receives gradual attention especially after 2004. There are also a small numbers of publications related to landslide. 
Nat. Hazards Earth Syst. Sci. Discuss., doi:10.5194/nhess-2016-112, 2016

Manuscript under review for journal Nat. Hazards Earth Syst. Sci.

Published: 11 May 2016

(c) Author(s) 2016. CC-BY 3.0 License.

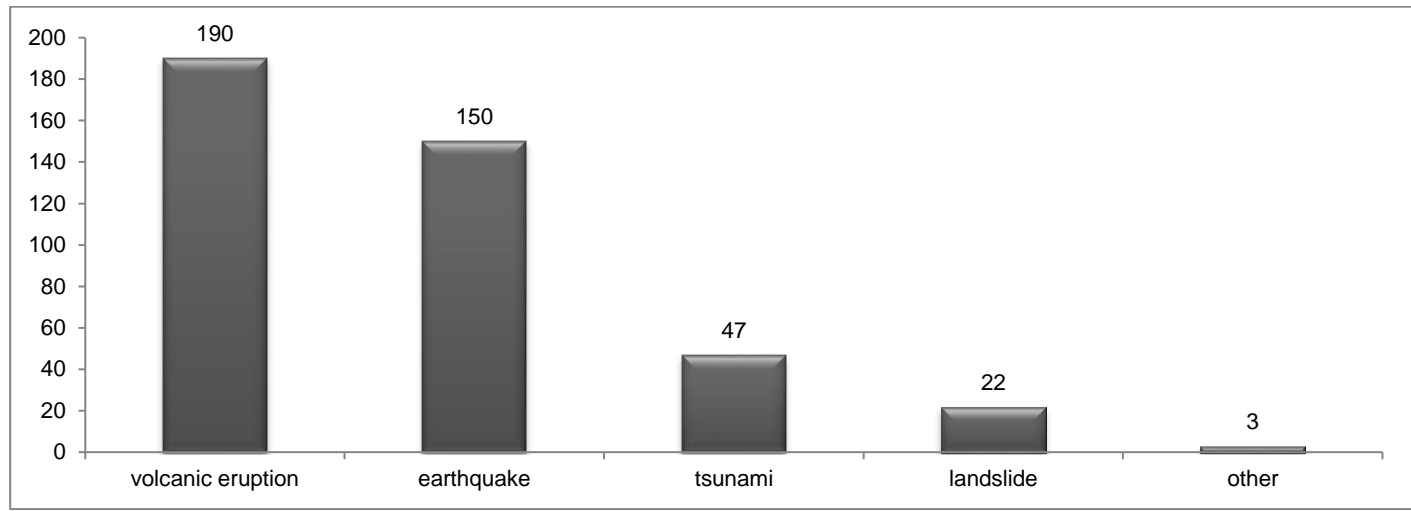

Figure 9 Types of Hazards, risks, disasters (total 413)

Figure 10 examines where these researches are focused worldwide, regionally or within Indonesia. As can be seed from the

Figure, the islands of Java and Sumatera are the two areas which receive examinations from the study. Correlating from the previous figure, the study in these two islands is mostly correlated to the study of volcanic eruption, earthquake and tsunami. This is not surprising considering that Indonesia has the most numbers of volcano, is located at the geographical ring or fire where earthquakes occur the most, and also has experienced and been impacted by one of the most powerful earthquake of 8.9 R.S which caused tsunami in 2004 and hit Aceh, which is located in the island of Sumatera (Ishii et al., 2005).

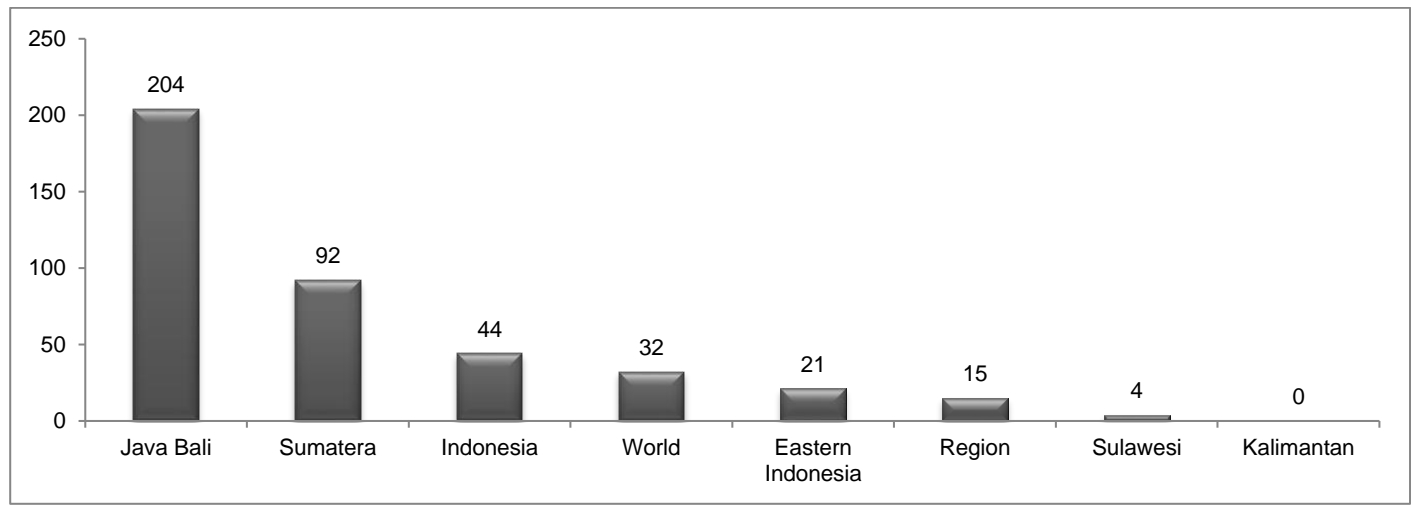

Figure 10 Where the research focus is located (total 413)

\subsubsection{Topic on disaster risk reduction}

The second sub-section explains the timelines, contents of researcher and locations inquired within or outside Indonesia on

the topic of disasters risk reduction. As can be seen from Figure 9, there have been very little publications published between 1978 and 2003. It is only after 2004 then there is a gradual increase of publications. The publication reach its peak in 2008, after that it slightly reduced, and then continue to increase and reach another peak in 2013. Only then publications have started to reduce. The oldest publications on DRR category is by Sudibyakto and Haroonah (1997) reviewing how disasters are managed from a social science perspective in the Indonesian journal Geography. 
Nat. Hazards Earth Syst. Sci. Discuss., doi:10.5194/nhess-2016-112, 2016

Manuscript under review for journal Nat. Hazards Earth Syst. Sci.

Published: 11 May 2016

(c) Author(s) 2016. CC-BY 3.0 License.

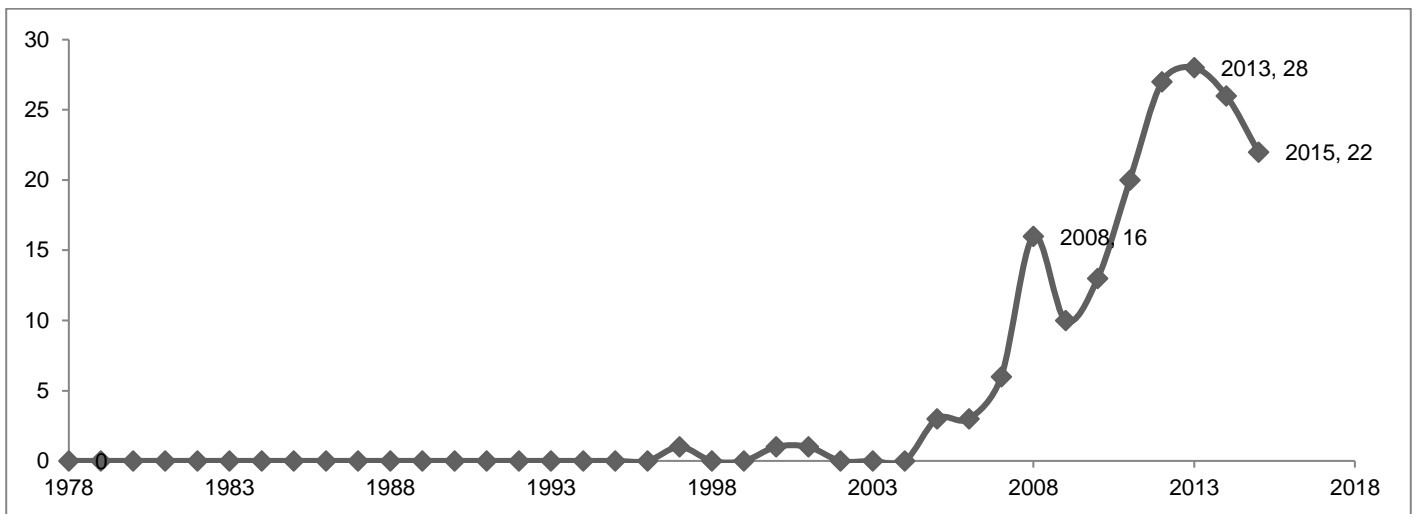

Figure 11 Number of publications in DRR over the year (total 177)

A close examination of 177 publications shows a very strong correlation between the issues discussed (Figure 12) and the locations (Figure 13). The topic that receives most attention in this category is related to the governance of DRR nationally (Bakkour et al., 2015; Chang Seng, 2013; Djalante et al., 2013; Djalante et al., 2012; Guarnacci, 2012). The next topic that receives greater attention is on the evaluation of recover and reconstruction that have taken place after the 2004 Indian Ocean tsunami which hit Aceh, located in the Island of Sumatera (Chang et al., 2011; Daly and Brassard, 2011; Godavitarne et al., 2006; Guarnacci, 2012; Karan and Subbiah, 2011; Telford and Cosgrave, 2007). Within the period after 2004, other topics that are also related to the impacts of tsunami and disasters in general is the role of culture, gender, or religion in helping the community to be resilient in facing disasters, and also how various disasters in Indonesia have impacted various community groups differently in relation to their culture or gender (Balgos et al., 2012; Baumann, 2008; Donovan, 2010; Donovan et al., 2012; Gaillard et al., 2008b; Guarnacci and Di Girolamo, 2012; Hiwasaki et al., 2015; Islam and Lim, 2015; Siagian et al., 2014).

Other topics that have been discussed were related to examination of early warning system especially in relation to tsunami early warning system that has been one of the focuses of the Indonesian government to install them around Indonesia. One notable initiative was the German Indonesian Tsunami Early Warning Systems (GITEWS) (e.g. Schlurmann and Siebert, 2011; Steinmetz et al., 2010). There are also a large number of publications which examine the role of knowledge and information to help the community be more prepared to disasters (Dicky et al., 2015; Hiwasaki et al., 2015; Rafliana, 2012). There are 13 publications comparing Indonesia and Sri Lanka in regards the impacts of the tsunami on how it either become the precursor for peace process in Indonesia but still take time for the process in Sri Lanka (Enia, 2008; Gaillard et al., 2008a; Hyndman, 2009; Kelman, 2005). Some lower numbers of papers examine community-based DRR which is strongly related to community preparedness (Adiyoso and Kanegae, 2013; Birkmann et al., 2015; Hidayati, 2012; James, 2008; Kusumasari and Alam, 2012), and others examine how children are affected psychologically from continuous exposures to hazards and disasters (Du et al., 2012; Lawler and Patel, 2012; Taylor and Peace, 2015; Vignato, 2012), and on emergency management at the local or national level (Djalante et al., 2012; Esteban et al., 2013; Kusumasari and Alam, 2012). 
Nat. Hazards Earth Syst. Sci. Discuss., doi:10.5194/nhess-2016-112, 2016

Manuscript under review for journal Nat. Hazards Earth Syst. Sci.

Published: 11 May 2016

(c) Author(s) 2016. CC-BY 3.0 License.

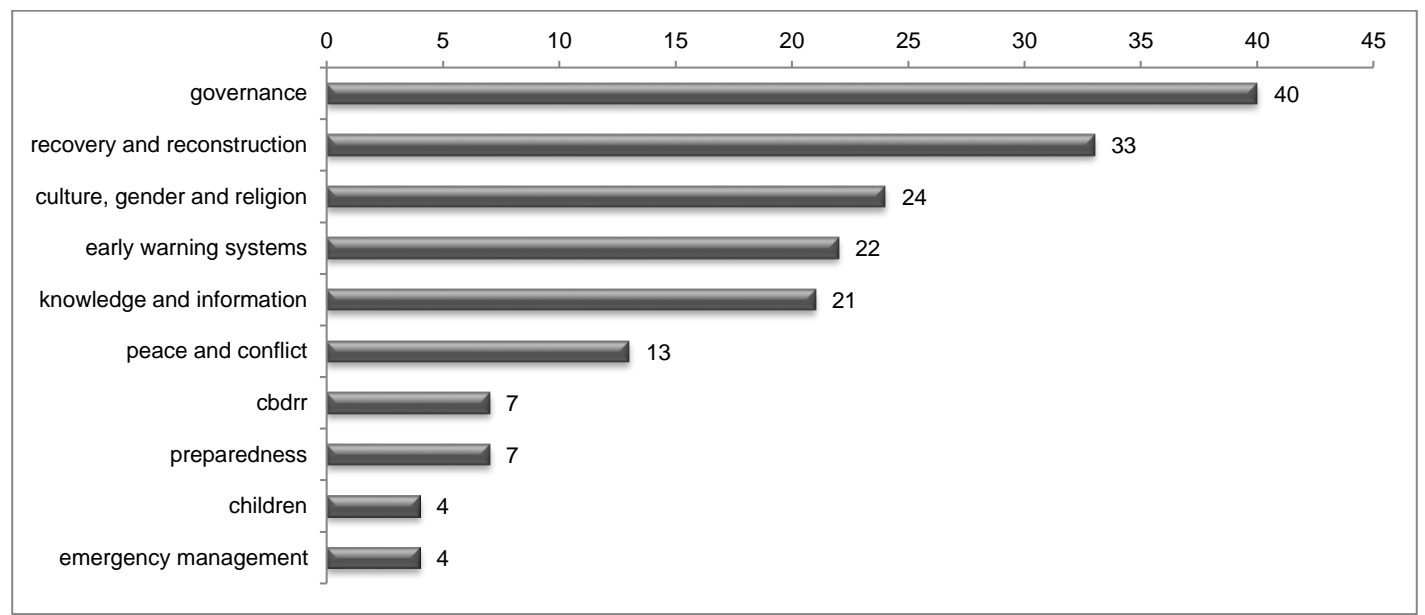

Figure 12 Key issues discussed in DRR literatures (total 177)

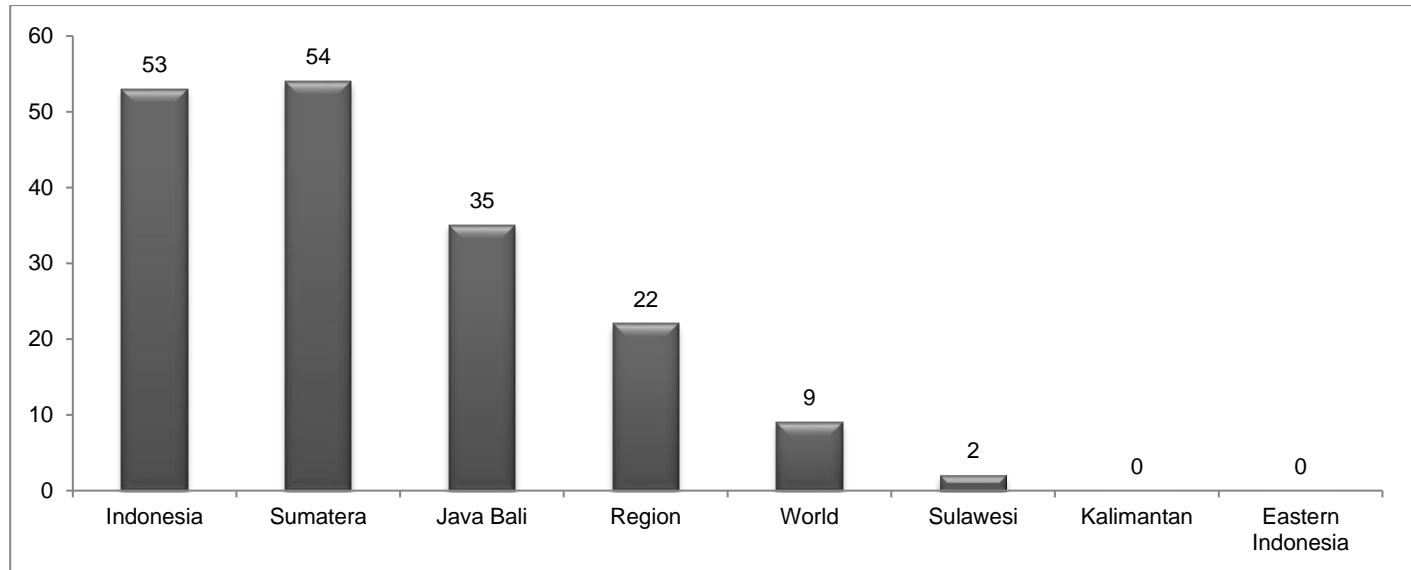

Figure 13 Locus of the research (total 177)

\subsubsection{Topics on climate change}

The third sub-section explains the timelines, contents of researcher and locations inquired within or outside Indonesia on the topic related to climate change. As can be seen from Figure 14, there has been few publications within the period between 1978 and 1990. The second period between 1990 to 2000 see a slight increase in literature, then there were 5 literatures published in 2001. These are related to examinations on the causes and impacts of the forest fires in Indonesia. The numbers of publications did not change in general until 2008. It is only after 2010 that there is a sharp increase in the numbers of publications and reach its peak in 2015 of 35 papers. The earliest publication was in 1992 by Subijakto (1992) who examine the facts and future trends of climate change: a case study of the eastern part of the Indonesia islands. Other paper that examine the management of climate change impacts in Indonesia is written by Murdiyarso (1993), in the Chemosphere Journal on the Policy options to reduce $\mathrm{CO}^{2}$ release resulting from deforestation and biomass in Indonesia. 
Nat. Hazards Earth Syst. Sci. Discuss., doi:10.5194/nhess-2016-112, 2016

Manuscript under review for journal Nat. Hazards Earth Syst. Sci.

Published: 11 May 2016

(c) Author(s) 2016. CC-BY 3.0 License.

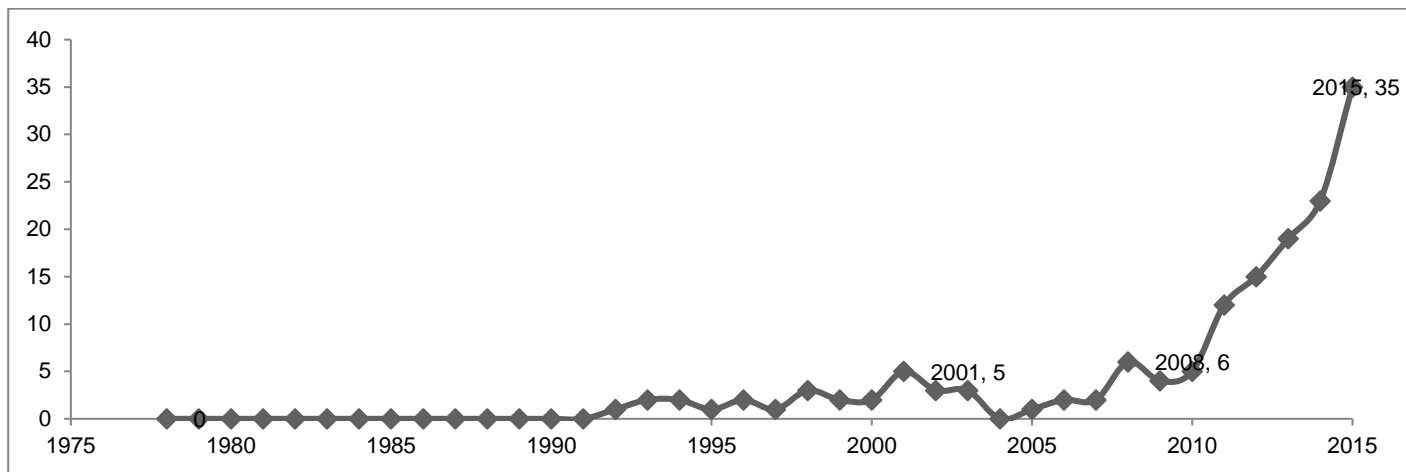

Figure 14 Number of publications on the topic of climate change (total 154)

As shown in Figure 15, the author categorizes the 154 publications in this group into three major discussions related to the impacts of climate change on Indonesia, on the governance of climate change adaptation, and also on there is a significant numbers of publications related to the issues of deforestation and land degradation which has taken enormous impacts on Indonesian rain forest. Indonesia is one of the countries that house some of the largest coverage of rainforest in the world especially in the islands of Sumatera and Kalimantan.

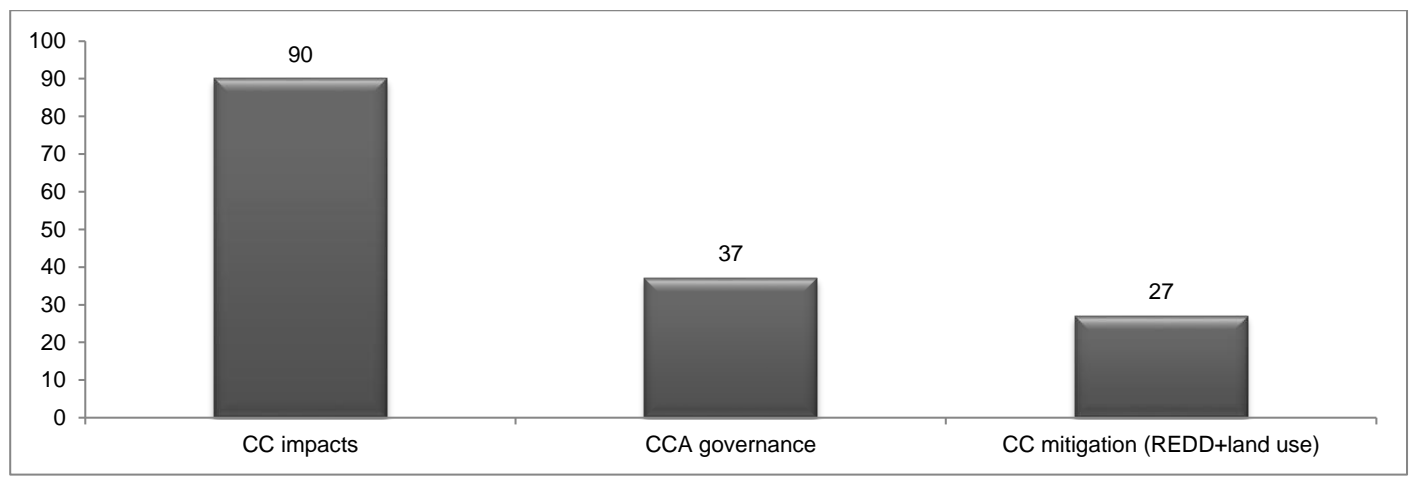

Figure 15 Key issues discussed in climate change literature (total 154)

Since the majority of materials published in this category are related to the review on the impacts on climate change in Indonesia, this paper examines deeper on those literature (Figure 16). It is shown that the impact on crops production, mainly on rice has been the majority of those researches (Caruso et al., 2016; D'Arrigo et al., 2011; D'Arrigo and Wilson, 2008; Kawanishi and Mimura, 2015; Keil et al., 2009; Naylor et al., 2001; Sano et al., 2013; Shofiyati et al., 2014). This is strongly related to the examination of too much water which can cause flood (Marfai and King, 2008a; Marfai et al., 2008; Marfai et al., 2014, 2015; Muis et al., 2015; Neolaka, 2012, 2013; Sarminingsih et al., 2014; Shrestha et al., 2014)or too little water which can or have caused drought in Indonesia (Aldrian and Djamil, 2008; D'Arrigo and Smerdon, 2008; D'Arrigo and Wilson, 2008; D'Arrigo et al., 2006; Keil et al., 2009; Keil et al., 2008). A high number of researches are also done on linking droughts (D'Arrigo and Smerdon, 2008; D'Arrigo et al., 2006; Salafsky, 1994; Shofiyati et al., 2014) and fire (Brauer and Hisham-Hashim, 1998; Fang and Huang, 1998; Jim, 1999; Page et al., 2002; Stolle and Lambin, 2003; Stolle and Tomich, 1999; Usman and Hartono, 1997) occurrences especially those on forest fire. There are also research on sea level rise and its impacts on coastal areas. A small number of research focuses on temperature, rainfall (Aldrian and Djamil, 2008; 
Nat. Hazards Earth Syst. Sci. Discuss., doi:10.5194/nhess-2016-112, 2016

Manuscript under review for journal Nat. Hazards Earth Syst. Sci.

Published: 11 May 2016

(c) Author(s) 2016. CC-BY 3.0 License.

Chrastansky and Rotstayn, 2012; D'Arrigo and Wilson, 2008). The impact on health (Coughlan de Perez et al., 2015) and animal (Morwood et al., 2008; Purnomo et al., 2011) has also received some attention.

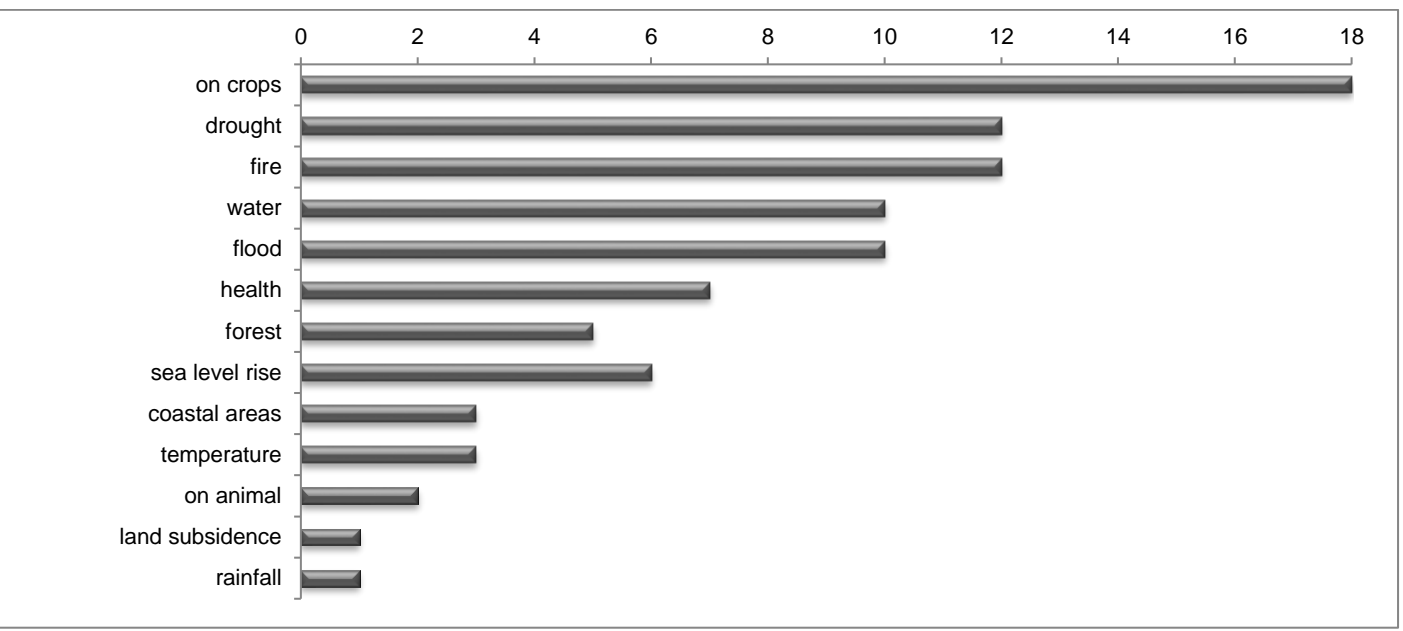

Figure 16 Key issues discussed in impacts of climate change (total 90)

In relation the area by which this research is located, the islands of Sumatera and Java has become the two major locations on the research of the impacts since they are the area where greatest paddy fields and crops productions are located (Figure 17). It is also great to see that various locations in Indonesia such as those in Sulawesi and also eastern part of Indonesia have received examinations in some of those studies.

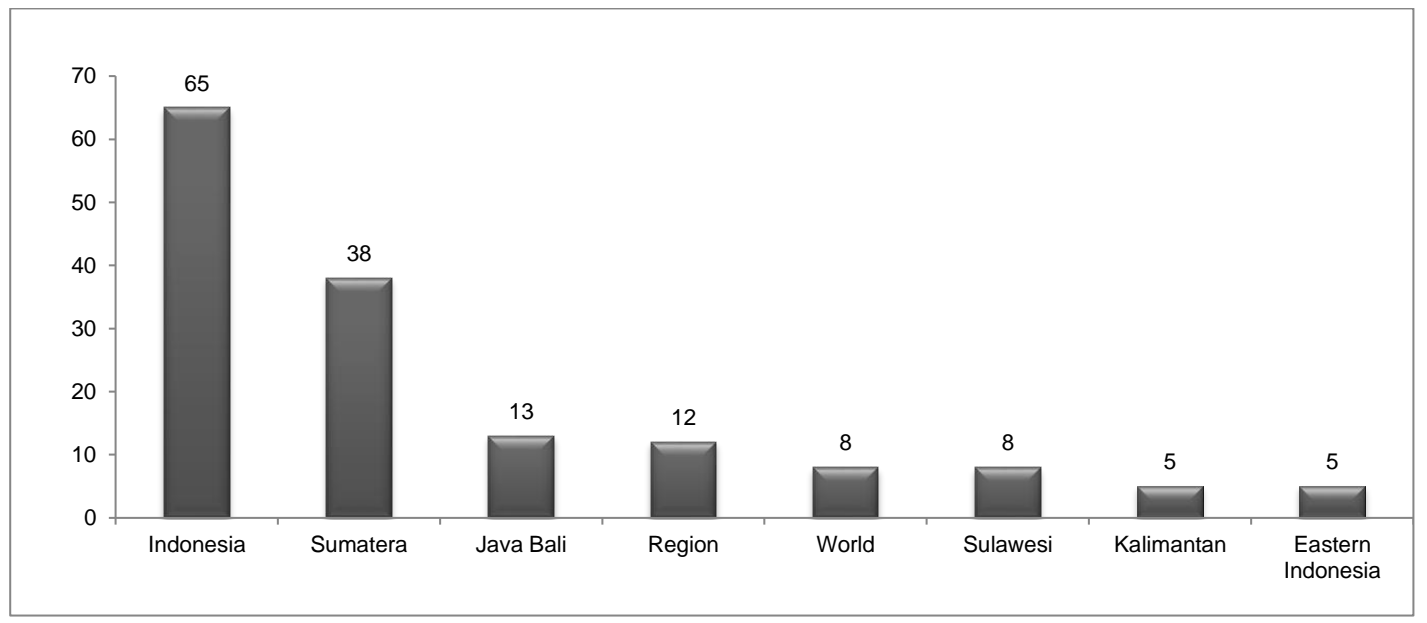

Figure 17 Where the research focus is located (total 154)

\subsection{Reviewing progress of Indonesian researchers and organizations}

This section examines the roles of Indonesian researchers and Indonesian organizations in contributing the production of those literatures, and also on how the Indonesian researchers have been in collaborating with other International / nonIndonesian organizations, and also in producing high quality papers. 
Nat. Hazards Earth Syst. Sci. Discuss., doi:10.5194/nhess-2016-112, 2016

Manuscript under review for journal Nat. Hazards Earth Syst. Sci.

Published: 11 May 2016

(c) Author(s) 2016. CC-BY 3.0 License.

\subsubsection{Authorships}

This study examines authorships of the publications in terms who published the most numbers of papers, and how Indonesian authors have been progressing in terms of publications. In general, the contribution of international / nonIndonesian authors dominates the productions of publications. The comparison shows that there are 2 international authors for every Indonesian author. Figure 18 shows there are more than double the number of international compared to Indonesians authors but more than half of the publications are co-authored by at least one Indonesian. In more detail, Figure 19 shows the comparison of involvement of Indonesian authors in the three major groups of publications. It can be seen that there are more authors in the hazards, risks and disaster assessments group, and the rest is divided almost equally by those in the other two groups.

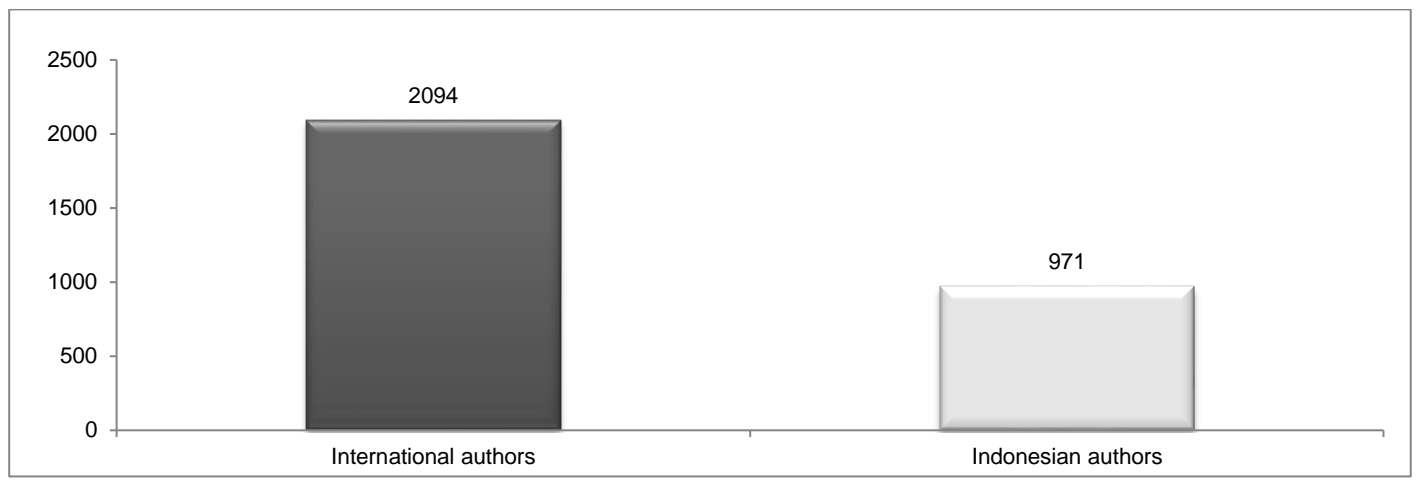

Figure 18 Comparing the numbers of Indonesian and non-Indonesian authors (total=3065)

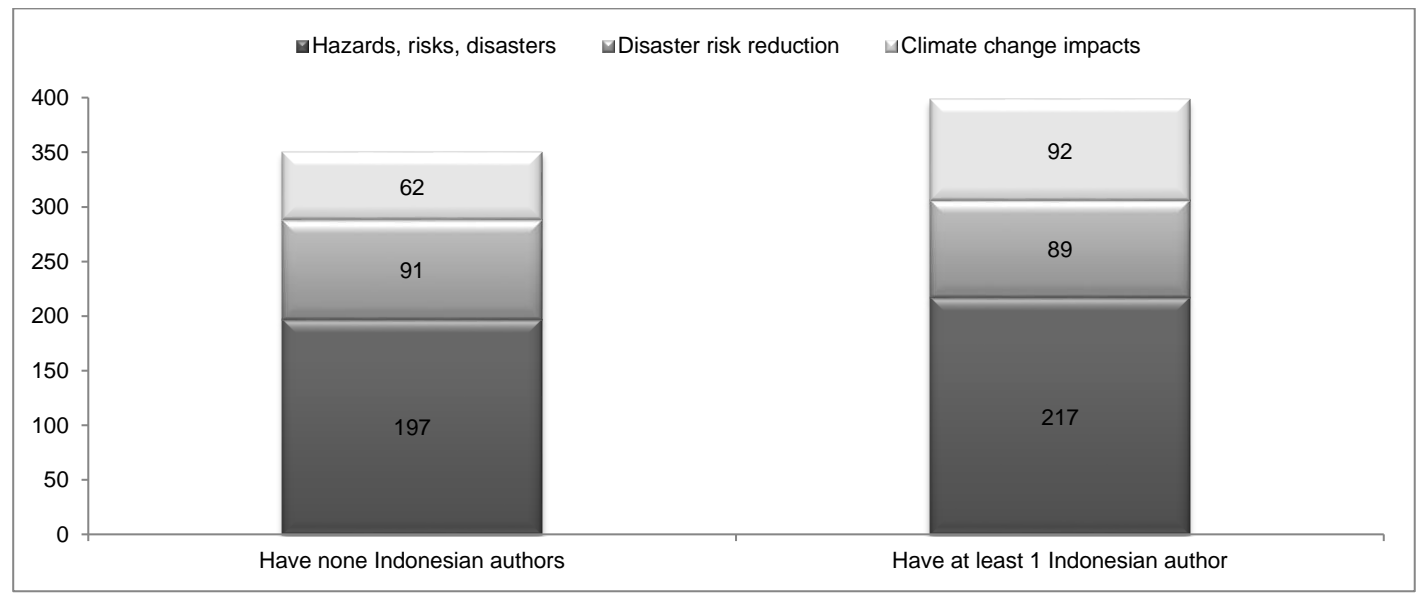

Figure 19 Comparing the number of Indonesian and non-Indonesian authors with 3 key research topics (Total 744)

Table 8 shows the list of top ten authors with highest number of publications. Frank Lavigne from Universite Paris 1 Pantheon Sorbonne published the highest numbers of papers (Google Scholar, 2016d). Lavigne worked closely with JC Thouret from Laboratory Magmas et Volcanis, who is in the $4^{\text {th }}$ list (LMV, 2016). Gertisser is a senior lecturer in Keele University (Google Scholar, 2016f). Voight is a renowned geologist and volcanologist in USA who have worked on the Mount Merapi since 1980s (Google Scholar, 2016b). Sieh has long collaborated with Natawidjaja on their works on seismology in Indonesia (EOS, 2016). Surono and Hendrasto are both affiliated with the PVMBG (PVMBG, 2016). Marfai 
Nat. Hazards Earth Syst. Sci. Discuss., doi:10.5194/nhess-2016-112, 2016

Manuscript under review for journal Nat. Hazards Earth Syst. Sci.

Published: 11 May 2016

(c) Author(s) 2016. CC-BY 3.0 License.

is affiliated at the Gadjah Mada University who has written on the topic of DRR, and also examination of hydrometeorological hazards and disasters (Google Scholar, 2016a).

Table 8 List of top ten authors with highest number of publications

\begin{tabular}{|c|c|c|c|c|c|c|}
\hline Author & $\begin{array}{l}\text { Organization / } \\
\text { Country }\end{array}$ & $\begin{array}{l}\text { Number } \\
\text { of } \\
\text { publicat } \\
\text { ion in } \\
\text { this } \\
\text { study }\end{array}$ & $\begin{array}{l}\text { SCOPUS } \\
\text { profile } \\
\text { (profile, } \\
\text { citations, h- } \\
\text { index, most } \\
\text { frequent } \\
\text { collaborator) }\end{array}$ & $\begin{array}{l}\text { Google } \\
\text { Scholar } \\
\text { profile } \\
\text { (publications, } \\
\text { citations, h- } \\
\text { index, i10- } \\
\text { index) } \\
\end{array}$ & $\begin{array}{l}\text { Research Gate } \\
\text { profile } \\
\text { (publications, } \\
\text { citations, } \\
\text { impact points) }\end{array}$ & Other profile \\
\hline Lavigne, Frank & $\begin{array}{l}\text { France / Universite } \\
\text { Paris 1 Pantheon } \\
\text { Sorbonne }\end{array}$ & 28 & $\begin{array}{l}62,1152,19, \\
\text { more than } 150,\end{array}$ & $\begin{array}{l}124,1648,21, \\
34\end{array}$ & $\begin{array}{l}153,1,430, \\
162.61\end{array}$ & \\
\hline Surono & $\begin{array}{l}\text { Indonesia / PVMBG } \\
\text { (Volcanology Survey } \\
\text { Indonesia) }\end{array}$ & 18 & $\begin{array}{l}27,348,12, \\
125,\end{array}$ & NA & NA & $\begin{array}{l}\text { https://en.wikipedia. } \\
\text { org/wiki/Surono_(v } \\
\text { olcanologist) }\end{array}$ \\
\hline $\begin{array}{l}\text { Abidin, } \\
\text { Hasanuddin Zainal }\end{array}$ & $\begin{array}{l}\text { Indonesia / Institute } \\
\text { Teknologi Bandung } \\
\text { (ITB) }\end{array}$ & 16 & $\begin{array}{l}\text { 53, 493, 11, } \\
\text { 121, Andreas } \\
\mathrm{H}\end{array}$ & $\begin{array}{l}172,1513,19, \\
35\end{array}$ & NA & $\begin{array}{l}\text { http://www.fitb.itb.a } \\
\text { c.id/en/hasanuddin.a } \\
\text { bidin/ }\end{array}$ \\
\hline Gertisser, Ralf & $\begin{array}{l}\text { United Kingdom / } \\
\text { Keele University }\end{array}$ & 15 & $\begin{array}{l}42,684,468,14, \\
\text { aboce } 150, \text { Char } \\
\text { bonnier SJ }\end{array}$ & NA & $\begin{array}{l}87 \\
803 \\
132,51 \\
\end{array}$ & $\begin{array}{l}\text { https://www.keele.a } \\
\text { c.uk/gge/people/ralf } \\
\text { gertisser/ }\end{array}$ \\
\hline Voight, Barry & $\begin{array}{l}\text { USA / Pennsylvania } \\
\text { State University }\end{array}$ & 14 & & NA & $\begin{array}{l}250 \\
5,307 \\
570.75 \\
\end{array}$ & \\
\hline Sieh, Kerry. & $\begin{array}{l}\text { Singapore / Earth } \\
\text { Observatory of } \\
\text { Singapore }\end{array}$ & 13 & $\begin{array}{l}120,5752,43, \\
\text { more than } 150, \\
\text { Natawidjaja, } \\
\text { DH }\end{array}$ & NA & NA & $\begin{array}{l}\text { http://www.earthobs } \\
\text { ervatory.sg/people/k } \\
\text { erry-sieh }\end{array}$ \\
\hline
\end{tabular}

395

Table 9 lists the Indonesian authors with 10 highest publications. The highest publications finally selected for the review of an Indonesian author is 18 publications by Surono of PVMBG. Abidin of the ITB has been listed to have 16 publications in this review, while his Google scholar profile shows that he has published extensively of 172, and with 1513 citations (Google Scholar, 2016e). There are a limited numbers of authors had been involved with publications to the highest IF journals such as Nature and Science. One of these authors is Natawidjaja who has 147 publications with total citations of 2964 based on his Google Scholar profile (Google Scholar, 2016c).

Table 9 List of Indonesian authors with top ten publications

\begin{tabular}{|lllll|}
\hline $\begin{array}{l}\text { Indonesian } \\
\text { Author }\end{array}$ & $\begin{array}{l}\text { No. of } \\
\text { publications in } \\
\text { this review }\end{array}$ & Org. & $\begin{array}{l}\text { SCOPUS profile (publications, citations, } \\
\text { h-index, co-authors, most frequent } \\
\text { collaborator) }\end{array}$ & $\begin{array}{l}\text { Google Scholar profile } \\
\text { (publications, citations, h-index,i- } \\
\text { 10 index) }\end{array}$ \\
\hline Surono, & 18 & $\begin{array}{l}\text { PVMB } \\
\text { G }\end{array}$ & $27,348,12,125$, Hendrasto M & NA \\
\hline Abidin, H.Z. & 16 & ITB & $53,493,11,121$, Andreas H & NA \\
\hline
\end{tabular}


Nat. Hazards Earth Syst. Sci. Discuss., doi:10.5194/nhess-2016-112, 2016

Manuscript under review for journal Nat. Hazards Earth Syst. Sci.

Published: 11 May 2016

(c) Author(s) 2016. CC-BY 3.0 License.

\begin{tabular}{|lllll|}
\hline $\begin{array}{l}\text { Natawidjaja, } \\
\text { D.H. }\end{array}$ & 11 & LIPI & $42,1913,21,123$, Sieh KE & $147,2964,25,33$ \\
\hline Marfai, M.A. & 11 & UGM & $19,183,8,36$, King, Lorenz & $79,517,12,14$ \\
\hline Hendrasto M & 10 & $\begin{array}{l}\text { PVMB } \\
\text { G }\end{array}$ & $16,92,4$, Surono & NA \\
\hline Andreas, H. & 10 & ITB & $20,123,6,46$, Abidin, H Z & NA \\
\hline $\begin{array}{l}\text { Ratdomopurbo, } \\
\text { A. }\end{array}$ & 8 & NTU & $17,441,10,59$, Lühr, B G & NA \\
\hline Muhari, A. & 8 & MAAF & $15,112,6,53$, Imamura, F & NA \\
\hline Sumarti, Sri. & 8 & UGM & $14,367,13,84$, Surono & NA \\
\hline Suwargadi, BW & 7 & LIPI & $31,1102,17,103$, Natawidjaja, DH & $97,1585,20,24$ \\
\hline
\end{tabular}

Figure 20 shows the distribution of Indonesian authors who have more than 1 publication selected in this review (see appendix 1 for full list of authors). There are 21 organizations located in Java and Bali, dominated by ITB and UGM, and there is 1 in Kalimantan, the University of Syiah Kuala (Aceh) and the University of Mataram (Lombok Island). There are 18 national level organizations such as LIPI, PVMBG, LAPAN, BMKG, Bakosurtanal, while 6 Indonesians are currently working outside Indonesia. In terms of distribution of males and females, the composition is almost 4 to 1 . There only 15 who has Goggle Scholar or Research Gate profiles.

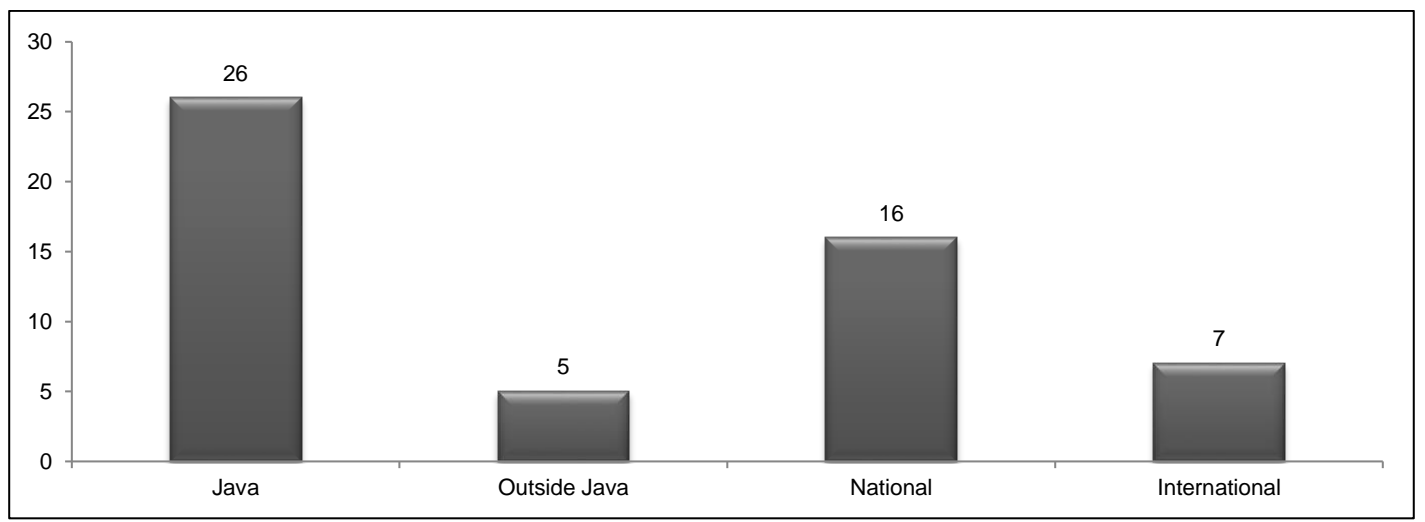

Figure 20 Composition of Indonesian authors with publications more than 1

This results show a great deal on the need for increasing the capacity of Indonesian authors to have the skills and experiences

in writing in English and submit for internationally regarded journal publications. Indonesian authors largely lack the experience in international collaborations and the language and writing skills necessary for submitting their works into internationally accredited journals. Despite some Indonesian researchers who have been strongly influential within the study of hazards, DRR or climate change in Indonesia and could potentially contribute to the global development of knowledge in these fields, they only published in Bahasa Indonesia and did not submit their works into international English written journals.

\subsubsection{Research centers/organizations affiliations}

This section examines the place and organizations by which the researchers are affiliated, systematically from the regional, to national, and amongst organizations in Indonesia. The organizations, which house ten most productive publications related to this review, are shown in Figure 21. In general, there are equal number of organizations that are based in Indonesia, and their contributions is comprised slightly more than half the overall contributions amongst these most productive agencies. 
Nat. Hazards Earth Syst. Sci. Discuss., doi:10.5194/nhess-2016-112, 2016

Manuscript under review for journal Nat. Hazards Earth Syst. Sci.

Published: 11 May 2016

(c) Author(s) 2016. CC-BY 3.0 License.

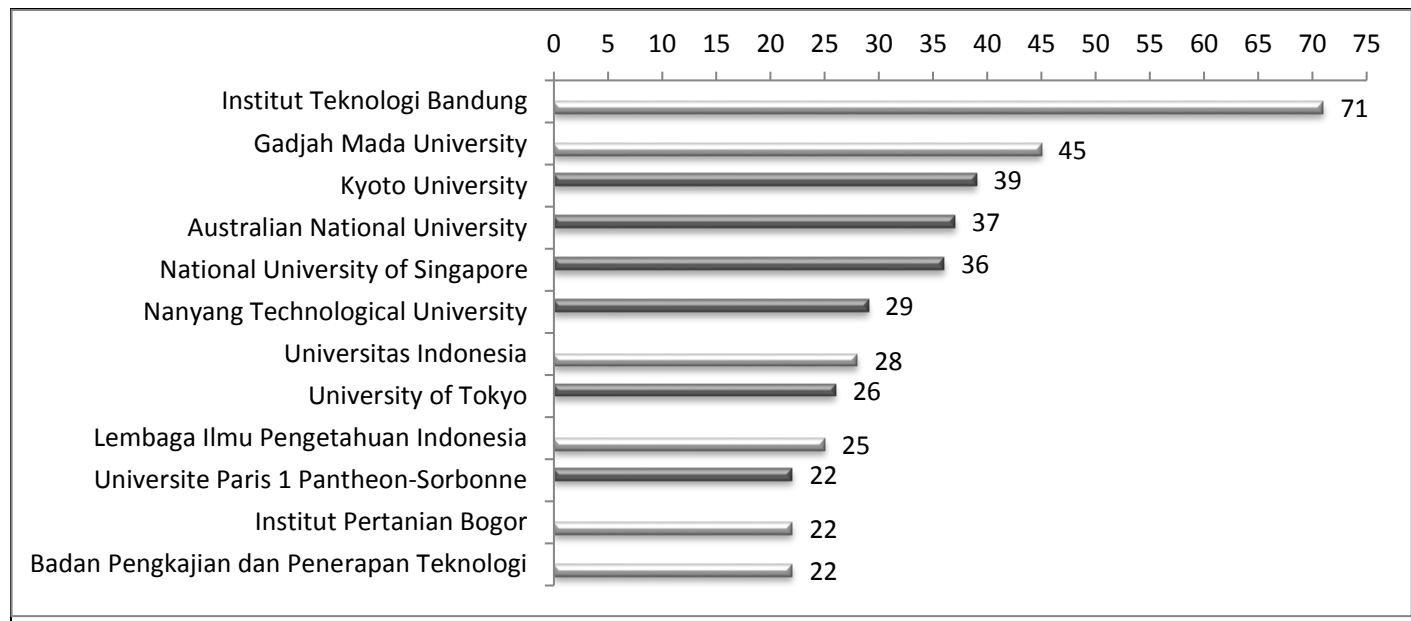

Figure 21 Organizations with highest number of publications

Figure 22 looks deeper on the contribution of different organizations within Indonesia. It is shown that ITB and UGM dominate almost half the total publications. There are also more twice universities in Java that those outside Java, while the rest of publications are contributed by national level organizations such as LIPI and PVMBG.

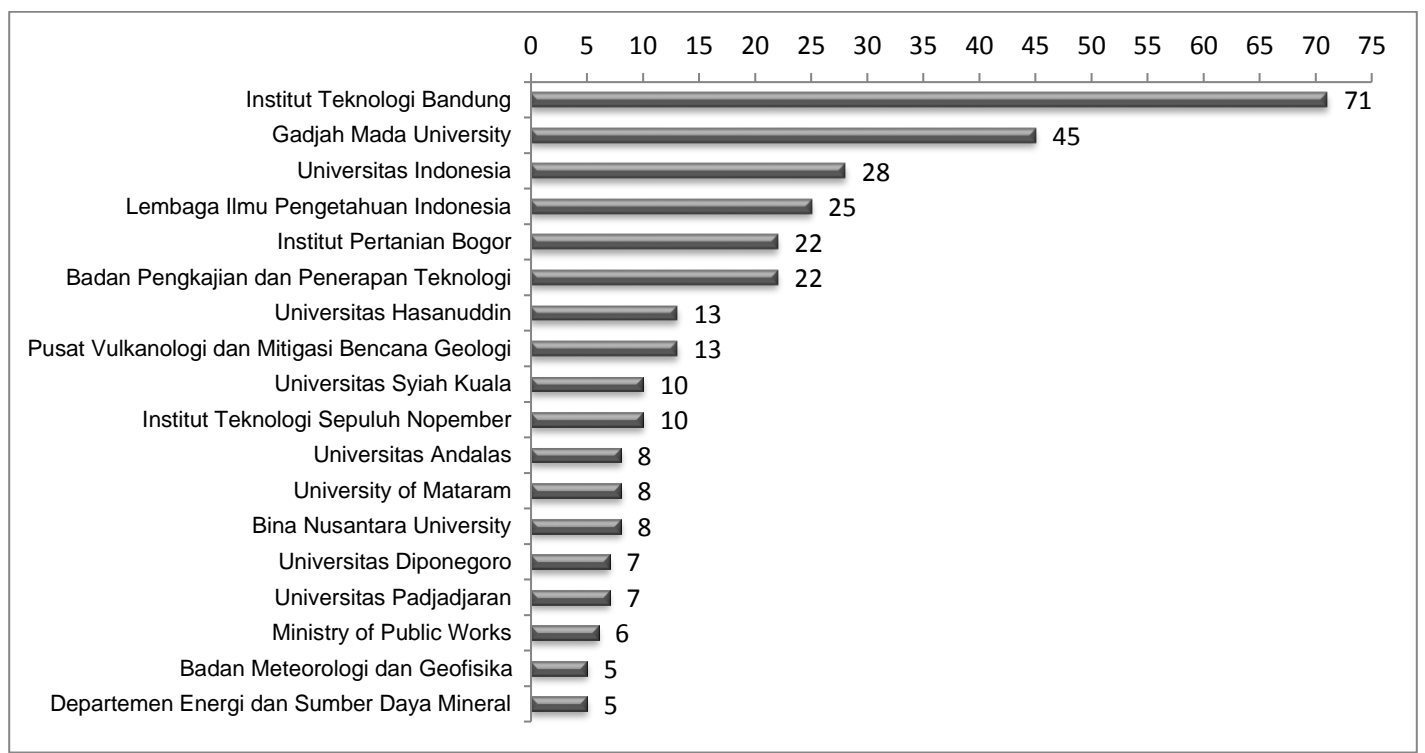

Figure 22 Contributions of Indonesian organizations

\subsubsection{Research quality measured through journal impact factor and number of citation}

This section presents the research quality of the publications, measured through the journal impact factors and the number of citations. Most importantly, it evaluates the progress of the Indonesian scholars through comparing their research outputs between papers first authored by Indonesian and overall papers. It does so through comparing the overall progress, and through examination of each research topic group. 
Nat. Hazards Earth Syst. Sci. Discuss., doi:10.5194/nhess-2016-112, 2016

Manuscript under review for journal Nat. Hazards Earth Syst. Sci.

Published: 11 May 2016

(c) Author(s) 2016. CC-BY 3.0 License.

\subsubsection{Overall}

This section the list of 10 most cited publications through comparing the roles of those published in general by any authors, and those publications that are published by an Indonesia first author. Figure 23 shows the comparison between the progress of Indonesian researchers in 10 most cited papers overall and those first authored by Indonesian. Important observations are that there are more authors in 10 most cited papers, more international authors in most 10 cited papers, more Indonesians in 10 cited paper first authored by Indonesian, 10 most cited papers have higher impact factor, and 10 most cited papers have higher citations. This might suggest that Indonesians researchers tend to work with other Indonesians and hence needed to expand their collaborations with international scholars as a strategy to increase the number of citations and ability to submit for higher impact journals.

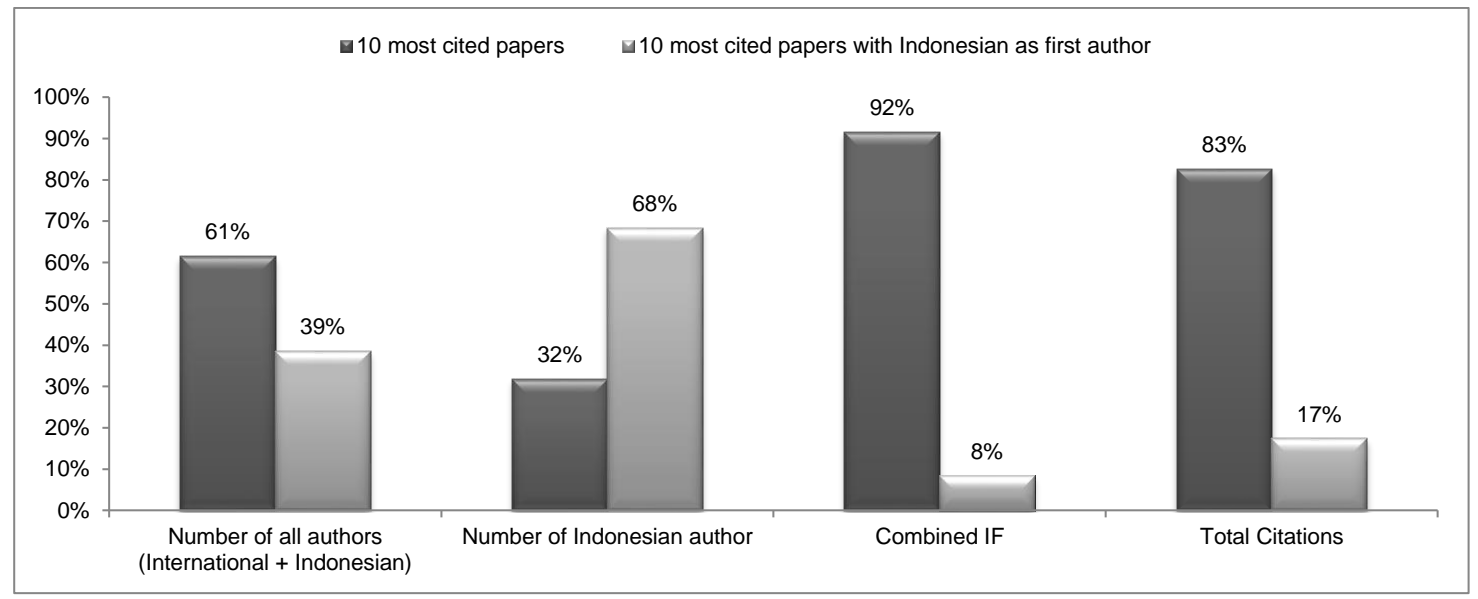

Figure 23 comparing the roles of Indonesian researchers in the 10 most cited papers

Table 10 shows the list of 10 most cited papers of all publications. With the 10 most cited papers, the total citations is 3,427 with combined impact factor (IF) is 256.013 , and there are only $32 \%$ of the authors are Indonesian, and none of them are first authors. It is shown that they are published in high impact factor journals such as Nature, Science, or those related to geophysical hazards. The two highest cited papers are published in Nature Journal and discussed the impacts on the forest fires in Indonesia. The paper related to the examination of the amount of carbon released from peat and forest fires in Indonesia in 1997 has the highest citation of 1156 by Page et al (2002), published in Nature. The majority of the paper discussed major hazards from earthquake in Sumatera (Briggs et al., 2006; Hsu et al., 2006; Ishii et al., 2005; Konca et al., 2008), and the rest review the impacts of Toba (Rampino and Self, 1992) and Merapi volcanic eruption (Voight et al., 2000).

There are 6 papers which also have Indonesians to contribute. Jaya and Limin are both lecturers from the Palangkaraya University in Kalimantan, where this forest fire occurred across the rain forest and impacted not only Indonesia but also the countries in the region such as Singapore (Tay, 1998) and Malaysia (Khandekar et al., 2000). Subarya, Natawidjaja, along with Sieh contributed the most (Briggs et al., 2006; Hill et al., 2012; Horspool et al., 2014; Hsu et al., 2006; Konca et al., 2008; Muhari et al., 2010; Nalbant et al., 2005; Philibosian et al., 2012; Prayoedhie et al., 2012; Schlurmann et al., 2010; Singh et al., 2010).

A closer examination on the list of ten most cited publications with Indonesian as first author shows a very striking picture.

Table 11 shows the list of 10 most cited papers by Indonesian as first author. The total citations is only 720 , with combined IF of only 23,492 , with $80 \%$ of the authors are Indonesian. The papers are much more varied in terms of topics they 
Nat. Hazards Earth Syst. Sci. Discuss., doi:10.5194/nhess-2016-112, 2016

Manuscript under review for journal Nat. Hazards Earth Syst. Sci.

Published: 11 May 2016

(c) Author(s) 2016. CC-BY 3.0 License.

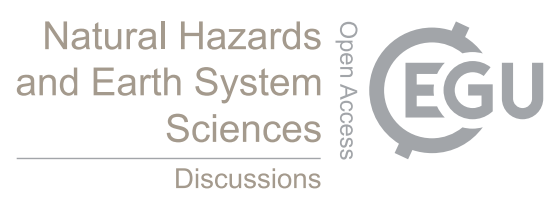

(c) (i)

470 discussed. There is no single paper in this Table that become the 10 most cited paper overall. The first two most cited papers are related to impacts of climate change in Indonesia. Aldrian (2003), Susanto (2003; 2001) and Amien et al (1996) authored papers related to climate change or its impacts on Indonesia. There are papers that examine impacts of volcano (Andreastuti et al., 2000; Widiwijayanti et al., 2009), earthquake (Irsyam et al., 2008) and tsunami (Muhari et al., 2011), while the rest examine land subsidence in Jakarta (Abidin et al., 2011) and progress of DRR governance nationally (Djalante et al., 2012). 
Nat. Hazards Earth Syst. Sci. Discuss., doi:10.5194/nhess-2016-112, 2016

Manuscript under review for journal Nat. Hazards Earth Syst. Sci.

Published: 11 May 2016

(c) Author(s) 2016. CC-BY 3.0 License.
Natural Hazards and Earth System Sciences

Discussions

\section{(c) (1)}

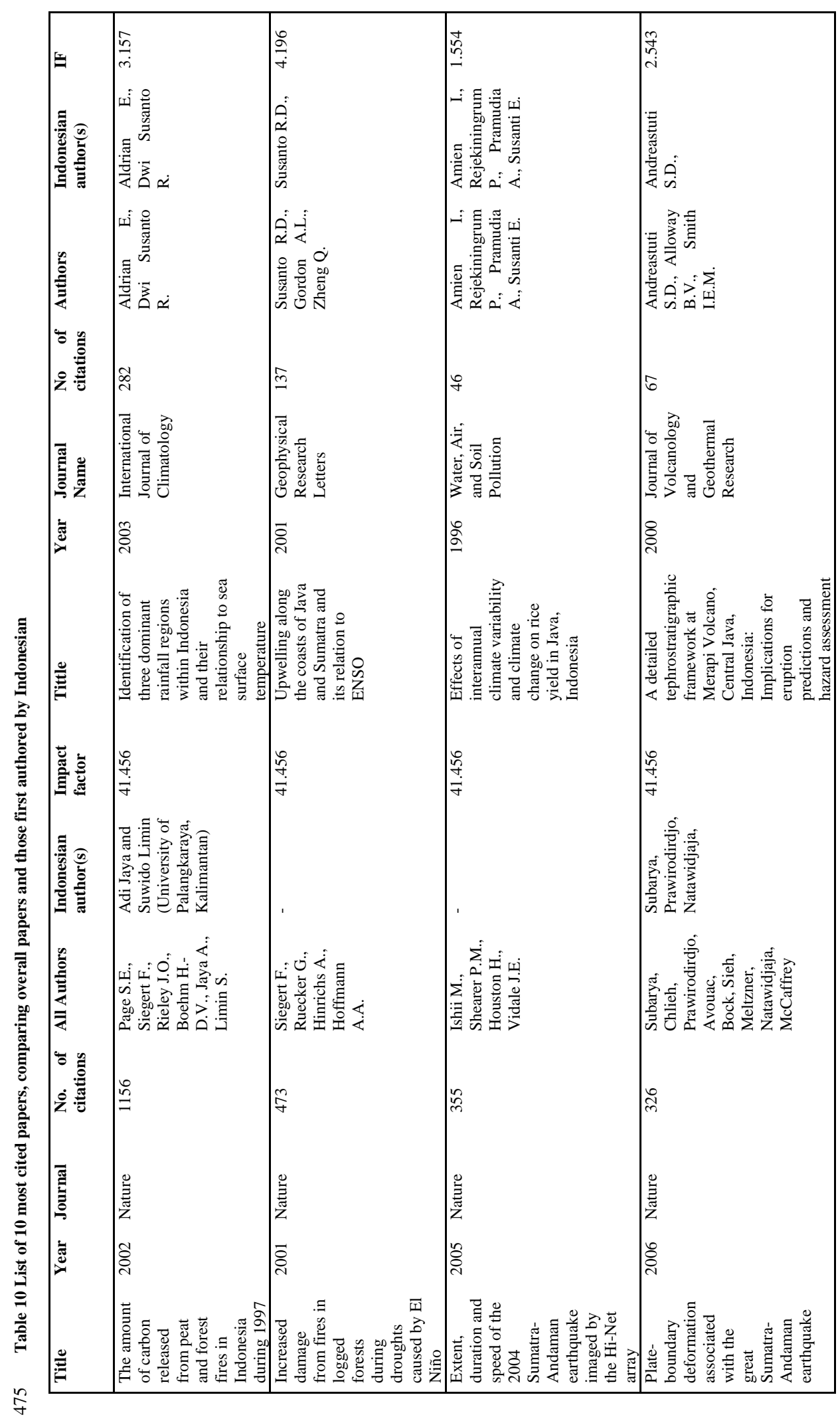

$\pi$ 
Nat. Hazards Earth Syst. Sci. Discuss., doi:10.5194/nhess-2016-112, 2016

Manuscript under review for journal Nat. Hazards Earth Syst. Sci.

Published: 11 May 2016

(c) Author(s) 2016. CC-BY 3.0 License.
Natural Hazards and Earth System Sciences

Discussions (c)

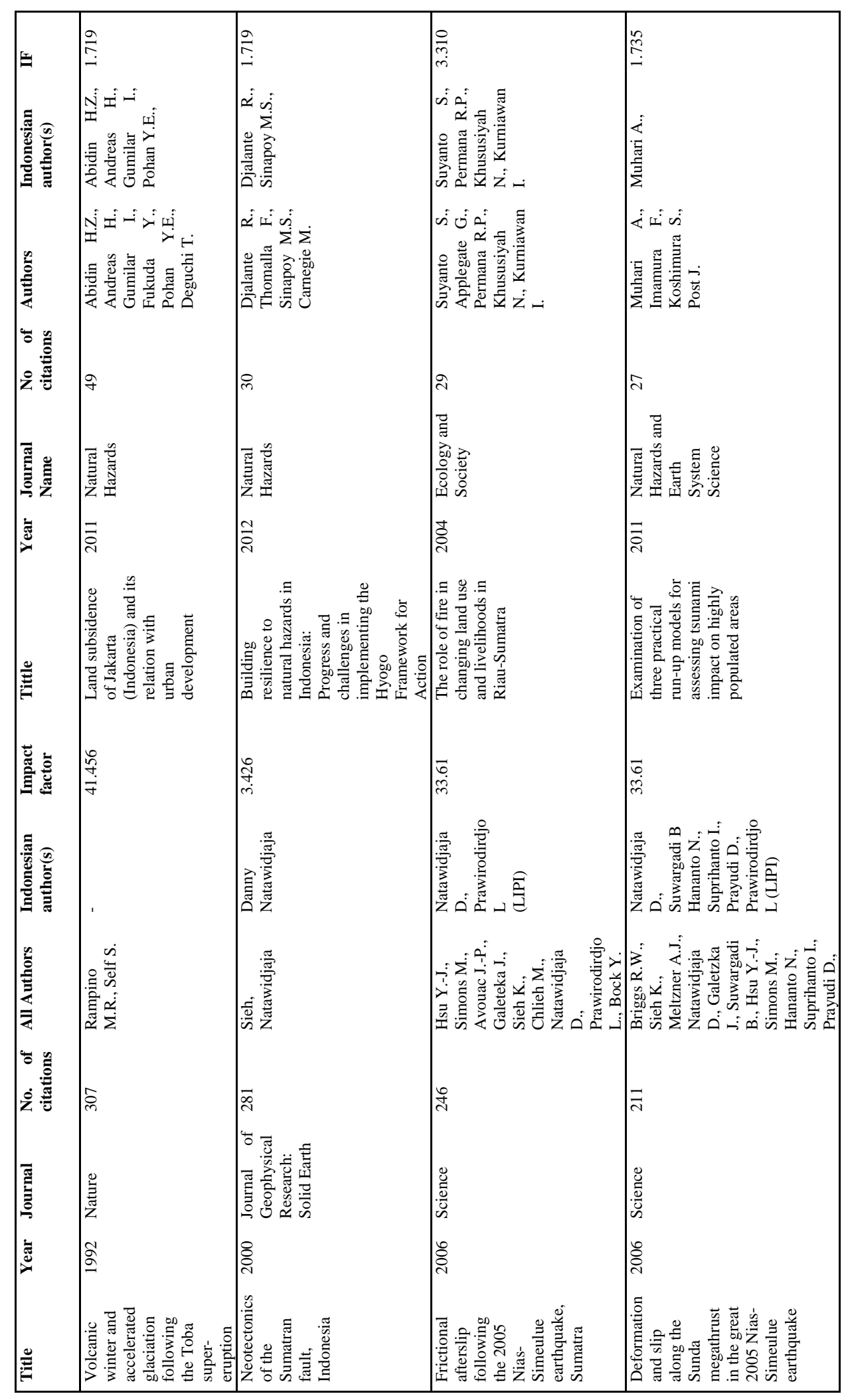


Nat. Hazards Earth Syst. Sci. Discuss., doi:10.5194/nhess-2016-112, 2016

Manuscript under review for journal Nat. Hazards Earth Syst. Sci.

Published: 11 May 2016

(c) Author(s) 2016. CC-BY 3.0 License.
Natural Hazards and Earth System Sciences

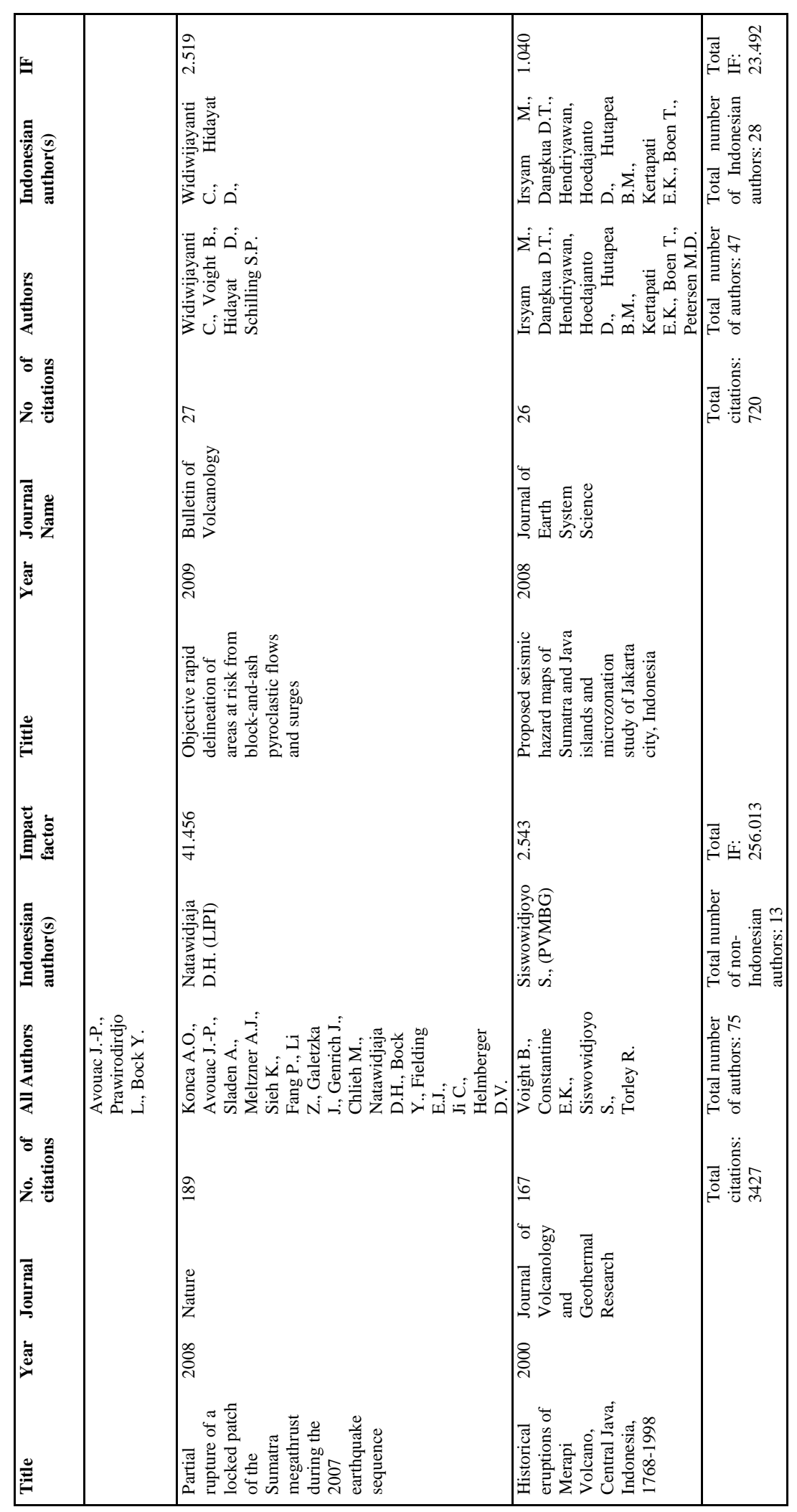


Nat. Hazards Earth Syst. Sci. Discuss., doi:10.5194/nhess-2016-112, 2016

Manuscript under review for journal Nat. Hazards Earth Syst. Sci.

Published: 11 May 2016

(c) Author(s) 2016. CC-BY 3.0 License.

\subsubsection{Topics on hazards, risks, and disasters assessments}

This sub-section examines the roles of Indonesian researchers in the publications of materials related to the topic of hazards, risks and disasters assessments. As can be seen from Figure 24, there are twice the number of authors in the most cited papers than the Indonesians, while the opposite occurs in when comparing the 10 cited papers with Indonesian as first author.

This shows that Indonesian authors needed to collaborate more with international authors. A very striking Figure is shown when examining the impacts of the publications. The total combined impact factor and citations are more than 9 times greater when comparing 10 most cited papers in general to those first authored by Indonesians. This shows how lacking the quality and impact of publications written by Indonesian scholars in general. Nature and Science are the two most frequent journals while Natawidjaja and Siswowidjoyo are the only 2 Indonesian authors in the 10 most cited papers overall. There are Indonesians in every paper that is first authored by an Indonesian. Those from ITB and UGM dominate the list.

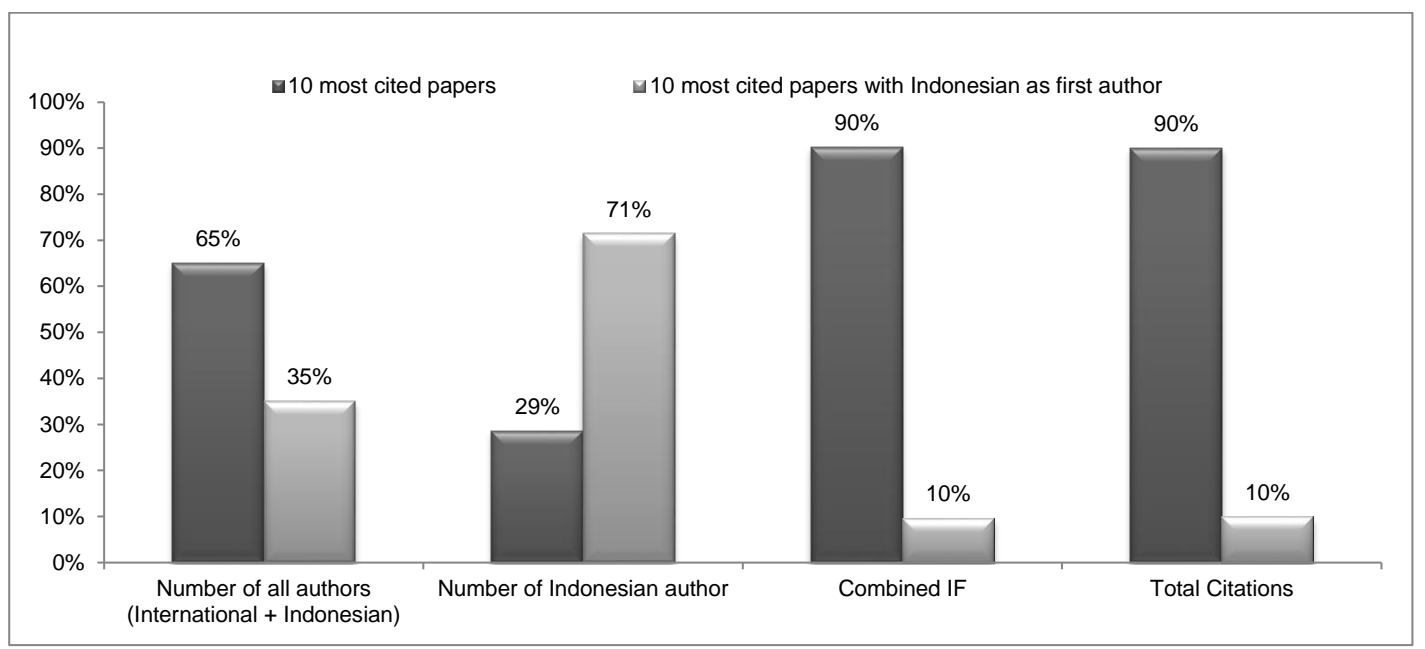

Figure 24 Comparing the role of Indonesian authors in 10 most cited publications in HRD categories

Table 11 lists ten most cited papers in the category of hazards, risks and disaster assessments. There are six papers examine earthquake in Sumatera, and two talks about the impact of Toba super-eruption, and the rest talk about Merapi volcano. The highest cited paper is that of Ishii M et al (2005) on the extent their examination of the 2004 Sumatran-Andaman earthquake which caused the Indian Ocean tsunami. Along with Professor Natawidjaja, Professor Kerry Sieh has been involved in three of these most cited papers (Briggs et al., 2006; Hsu et al., 2006).

Table 11 shows the list of 10 most cited papers in this category with Indonesian as first author. Four papers discuss volcano, two papers discuss earthquake, and the rest discuss tsunami and landslide risks. One particular finding here is that there are 4 papers by which all authors are all Indonesians which also suggest that Indonesians researchers might still tend to work with other Indonesians and hence needed to expand their collaborations with international scholars as a strategy to increase the number of citations and ability to submit for higher impact journals. Andreastuti (2000) has the highest cited paper on the works on Merapi volcano, followed by the work of Abidin (2011) on land subsidence in Jakarta. 
Nat. Hazards Earth Syst. Sci. Discuss., doi:10.5194/nhess-2016-112, 2016

Manuscript under review for journal Nat. Hazards Earth Syst. Sci.

Published: 11 May 2016

(c) Author(s) 2016. CC-BY 3.0 License.
Natural Hazards and Earth System Sciences (c) (9)

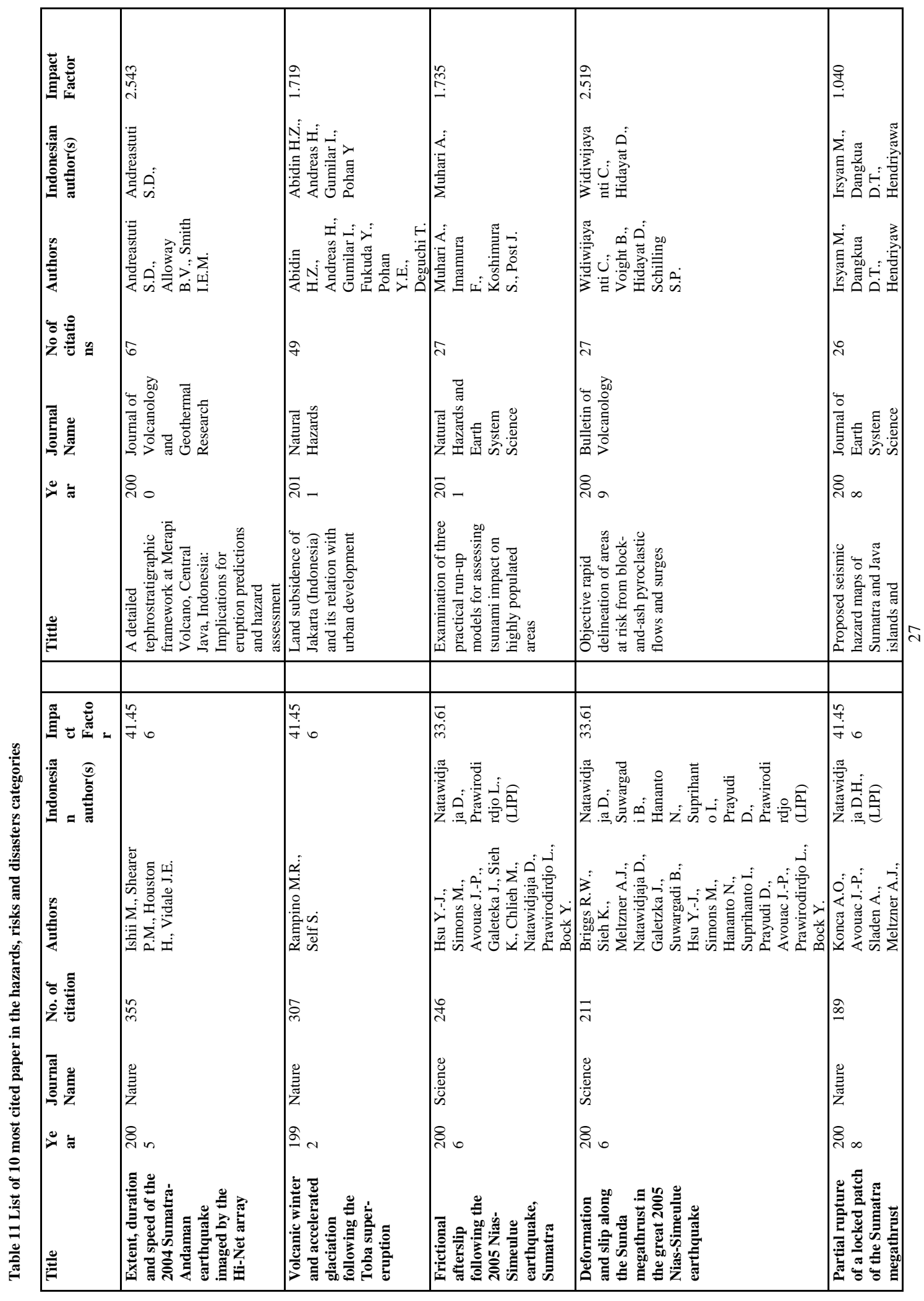


Nat. Hazards Earth Syst. Sci. Discuss., doi:10.5194/nhess-2016-112, 2016

Manuscript under review for journal Nat. Hazards Earth Syst. Sci.

Published: 11 May 2016

(c) Author(s) 2016. CC-BY 3.0 License.
Natural Hazards and Earth System

Sciences

Discussions

\section{(c) (1)}

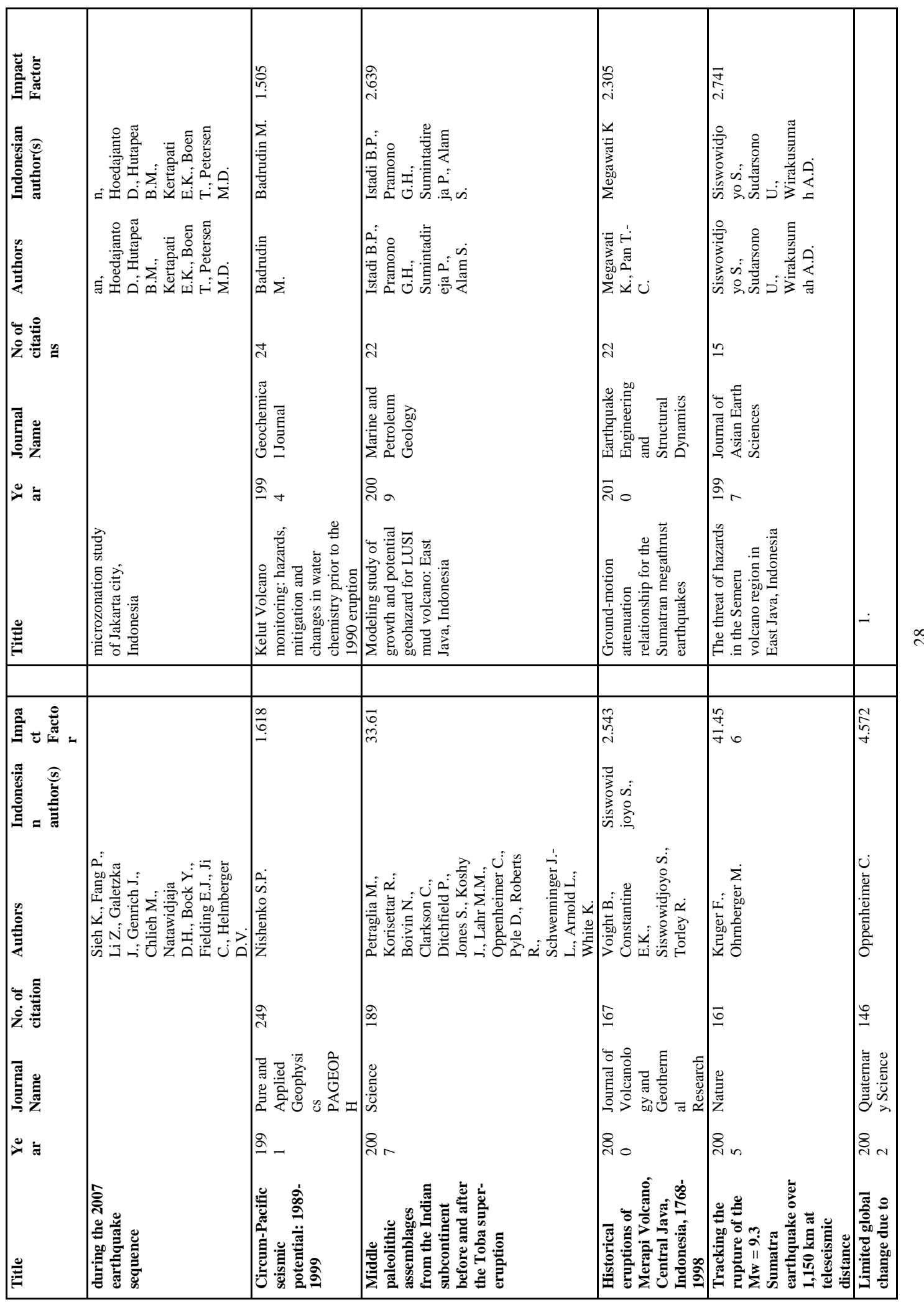


Nat. Hazards Earth Syst. Sci. Discuss., doi:10.5194/nhess-2016-112, 2016

Manuscript under review for journal Nat. Hazards Earth Syst. Sci.

Published: 11 May 2016

(c) Author(s) 2016. CC-BY 3.0 License.

(c) (i)
Natural Hazards 융 and Earth System Sciences

Discussions

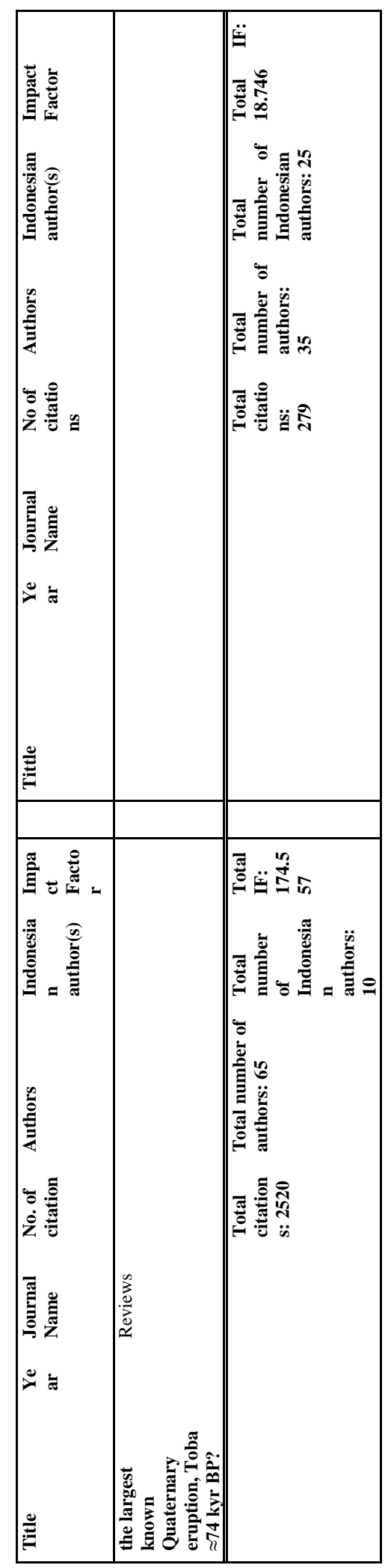


Nat. Hazards Earth Syst. Sci. Discuss., doi:10.5194/nhess-2016-112, 2016

Manuscript under review for journal Nat. Hazards Earth Syst. Sci.

Published: 11 May 2016

(c) Author(s) 2016. CC-BY 3.0 License.

\subsubsection{Topic on disaster risk reduction}

This sub-section examines the roles of Indonesian researchers in the publications of materials related to the topic of disaster risk reduction. As can be seen from Figure 25, there are twice the number of authors in the most cited papers than the Indonesians, while the opposite occurs in when comparing the 10 cited papers with Indonesian as first author. While the combined impact factor does not differ greatly, the total combined impact factor and citations are still 8 times greater when comparing 10 most cited papers in general to those first authored by Indonesians. Table 14 shows the 10 most cited papers in DRR group. Most papers discuss various aspects reviewing the 2004 tsunami recovery and reconstructions, from the building back-better (Kennedy et al., 2008), humanitarian system (Telford and Cosgrave, 2007), institutional (Birkmann et al., 2010) and ethnic groups (Gaillard et al., 2008b) responses, the role of the environment (Srinivas and Nakagawa, 2008), housing (Steinberg, 2007), peace (Le Billon and Waizenegger, 2007). The other papers discuss tsunami warning in Padang (Taubenböck et al., 2009) and disasters in general. This implies that Indonesian authors needed to collaborate more with international authors. Setiadi, formerly from UNU-EHS, was involved in two publications related to the GITEWS program following the 2004 Indian Ocean tsunami. This shows how lacking the quality and impact of publications written by Indonesian scholars in this topic. Djalante has 3 papers within the list of those first authored by Indonesian, on her publications related to the review of DRR governance in Indonesia (Table 12).

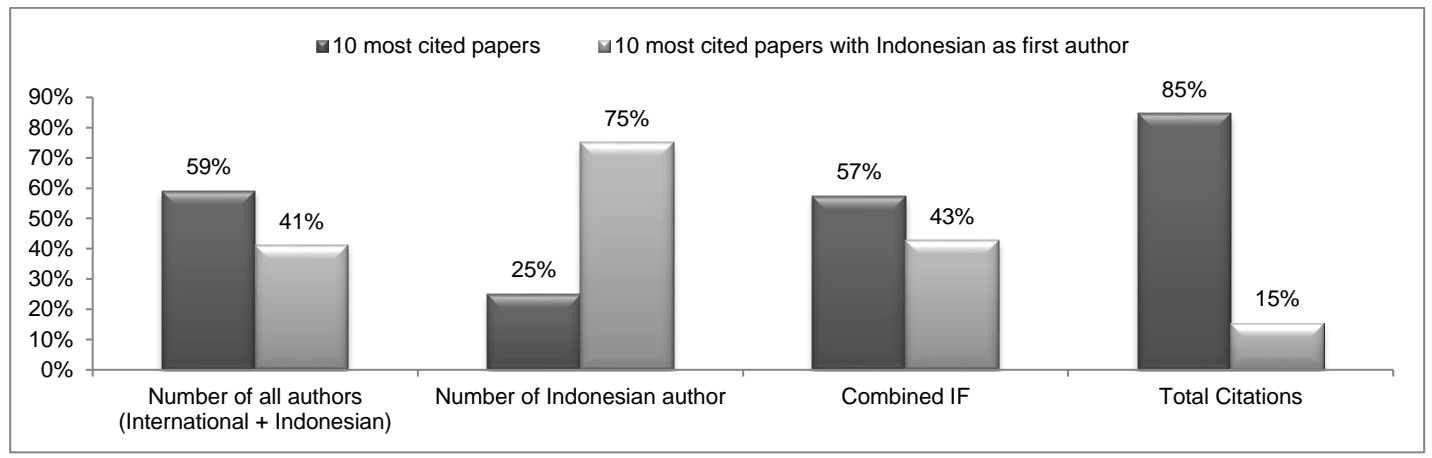

Figure 25 Comparing the role of Indonesian authors in 10 most cited publications in DRR categories 
Nat. Hazards Earth Syst. Sci. Discuss., doi:10.5194/nhess-2016-112, 2016

Manuscript under review for journal Nat. Hazards Earth Syst. Sci.

Published: 11 May 2016

(c) Author(s) 2016. CC-BY 3.0 License.
Natural Hazards and Earth System

Sciences

Discussions (c) ()

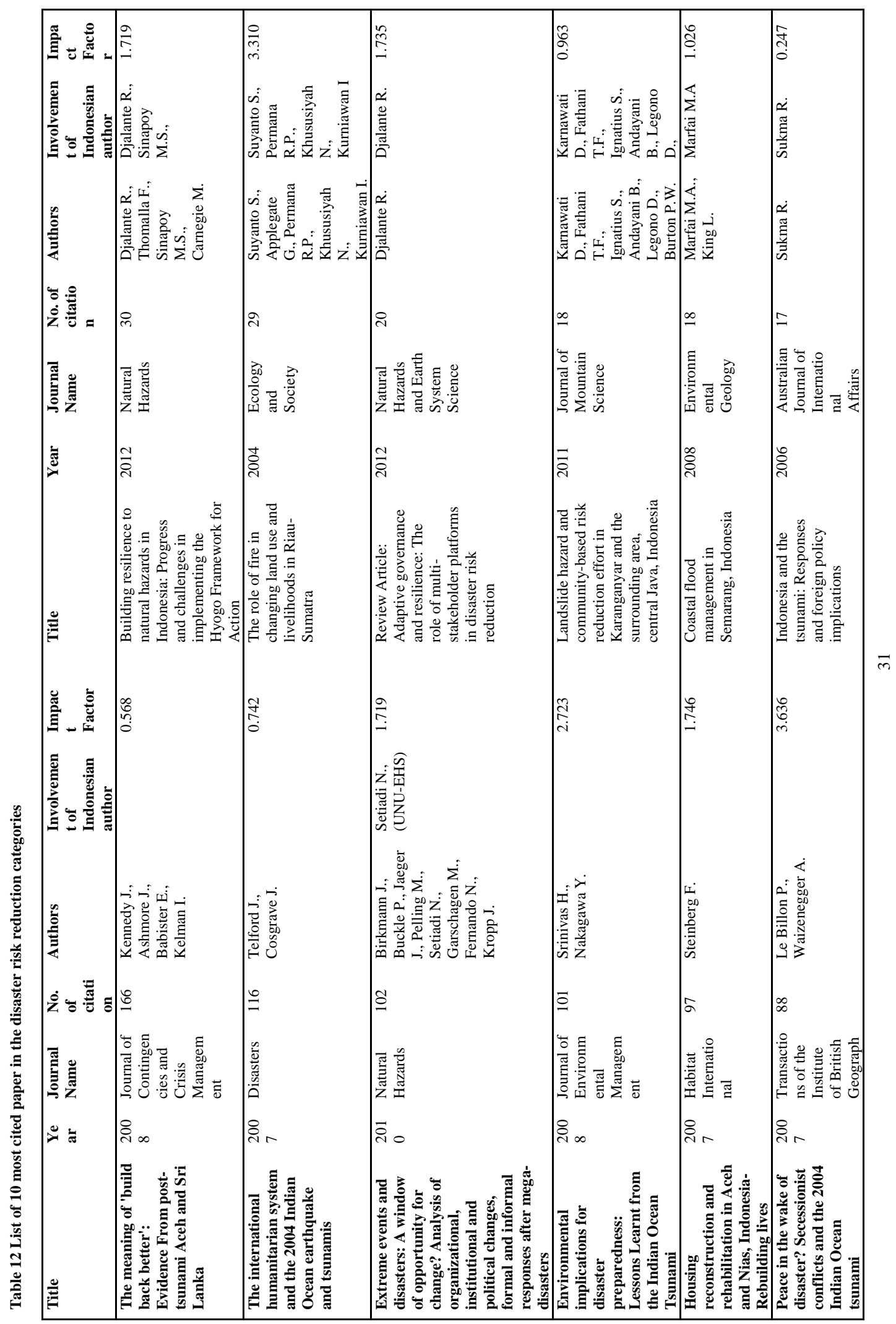


Nat. Hazards Earth Syst. Sci. Discuss., doi:10.5194/nhess-2016-112, 2016

Manuscript under review for journal Nat. Hazards Earth Syst. Sci.

Published: 11 May 2016

(c) Author(s) 2016. CC-BY 3.0 License.
Natural Hazards and Earth System

Sciences

Discussions

\section{(c) (i)}

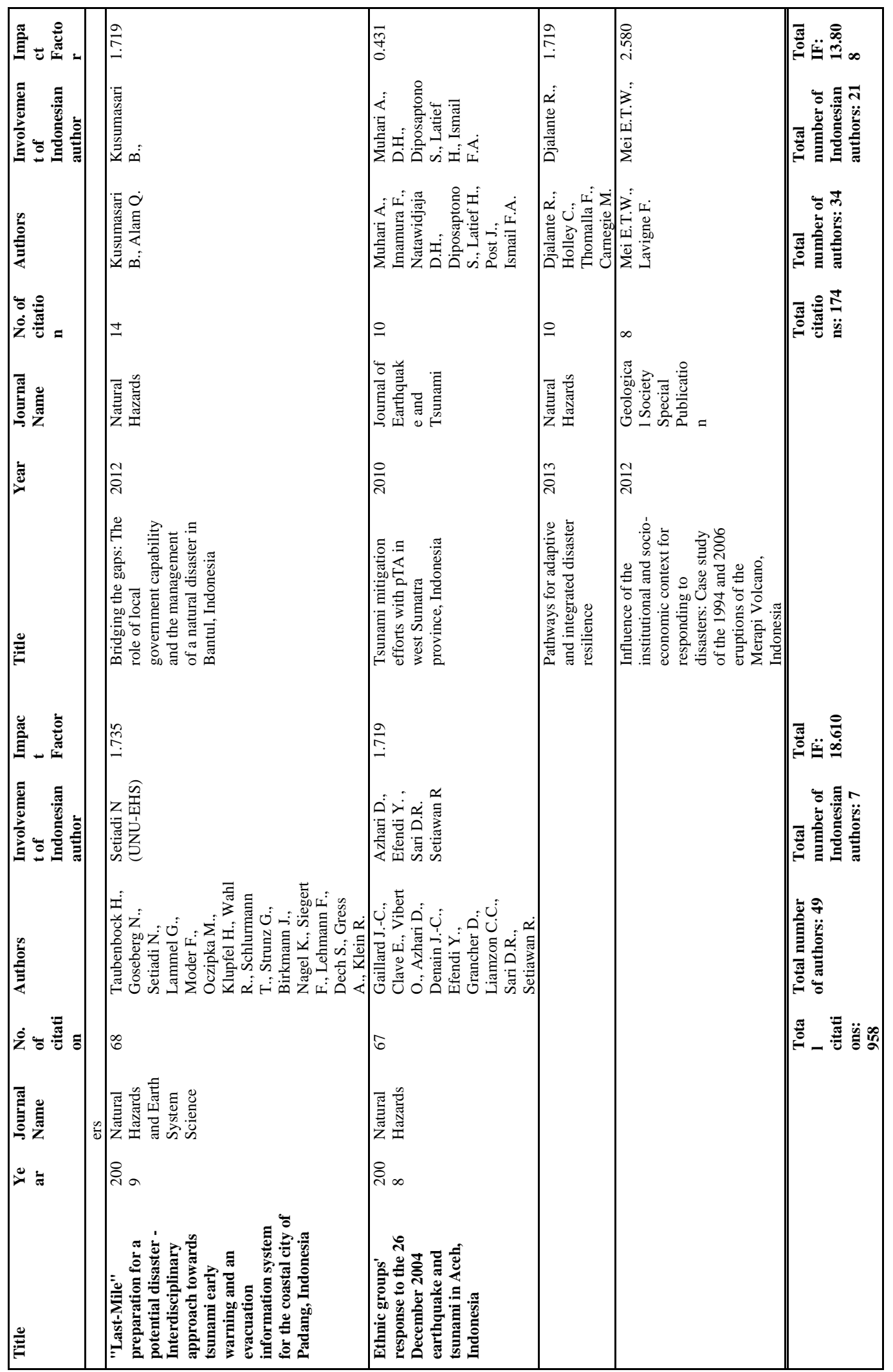

๗ี 
Nat. Hazards Earth Syst. Sci. Discuss., doi:10.5194/nhess-2016-112, 2016

Manuscript under review for journal Nat. Hazards Earth Syst. Sci.

Published: 11 May 2016

(c) Author(s) 2016. CC-BY 3.0 License.

\subsubsection{Topics on climate change}

This sub-section examines the roles of Indonesian researchers in the publications of materials related to the topic of climate change impacts and governance. As can be seen from Figure 26, there are more collaborations take place amongst authors in 10 most cited papers while almost 80 percent authors of 10 most cited papers with Indonesian as first authors, are Indonesian. While the impact factor of the papers differ greatly (9 times), the citations by the Indonesian first authors' publications catch up. Table 13 shows that majority of the papers talk about the Indonesian forest fires in relation to climate change. The other papers talk about observations of changes in rainfall, drought and temperature. Page et al has their paper on the amount of carbon released from forest fires as the highest cited paper in this category. There are two Indonesians, Jaya A., Limin S from Palangkaraya University in Kalimantan are involved in the most cited paper in this group on their paper (Page et al., 2002). Aldrin and have also published widely cited papers related to observations on changes in temperature and rainfall in Indonesia (Aldrian and Djamil, 2008; Aldrian and Dwi Susanto, 2003). Amien and Redjekiningrum from the Center for Soil and Agroclimate Research have collaborated in two papers on the examinations of possible climate change on rice production in Java (Amien et al., 1999). Marfai from UGM has two papers that examine the impacts of sea level rise on the coastal areas in Semarang (Marfai and King, 2008b; Marfai et al., 2008).

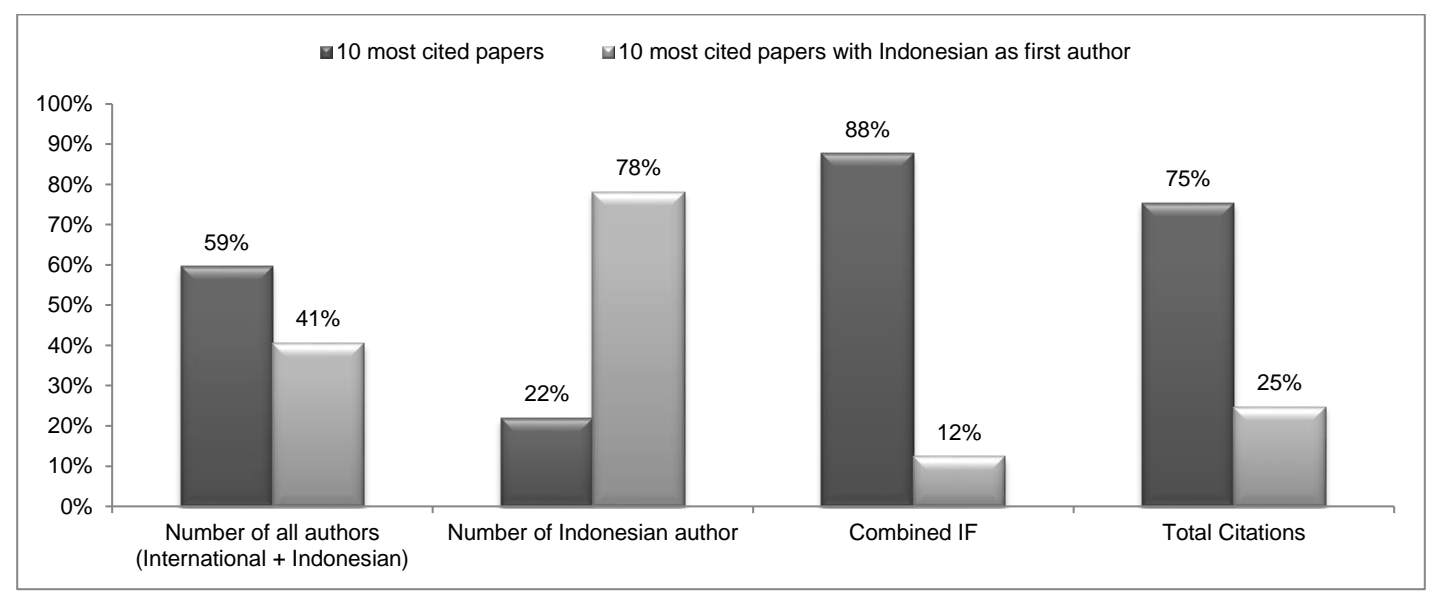

Figure 26 Comparing the role of Indonesian authors in 10 most cited publications 
Nat. Hazards Earth Syst. Sci. Discuss., doi:10.5194/nhess-2016-112, 2016

Manuscript under review for journal Nat. Hazards Earth Syst. Sci.

Published: 11 May 2016

(c) Author(s) 2016. CC-BY 3.0 License.
Natural Hazards and Earth System Sciences

Discussions

\section{(c) (1)}

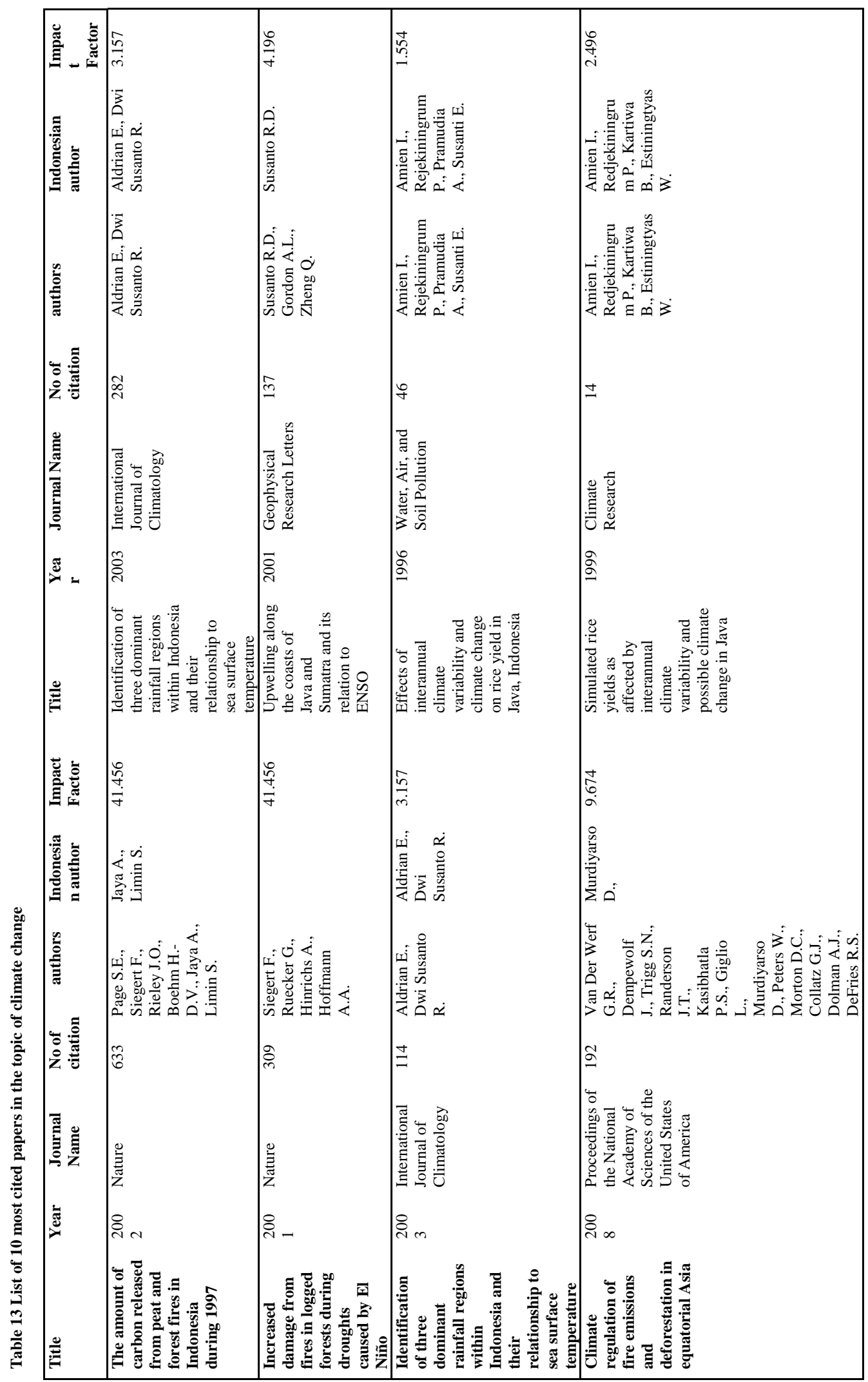


Nat. Hazards Earth Syst. Sci. Discuss., doi:10.5194/nhess-2016-112, 2016

Manuscript under review for journal Nat. Hazards Earth Syst. Sci.

Published: 11 May 2016

(c) Author(s) 2016. CC-BY 3.0 License.
Natural Hazards and Earth System Sciences

Discussions

\section{(c) (1)}

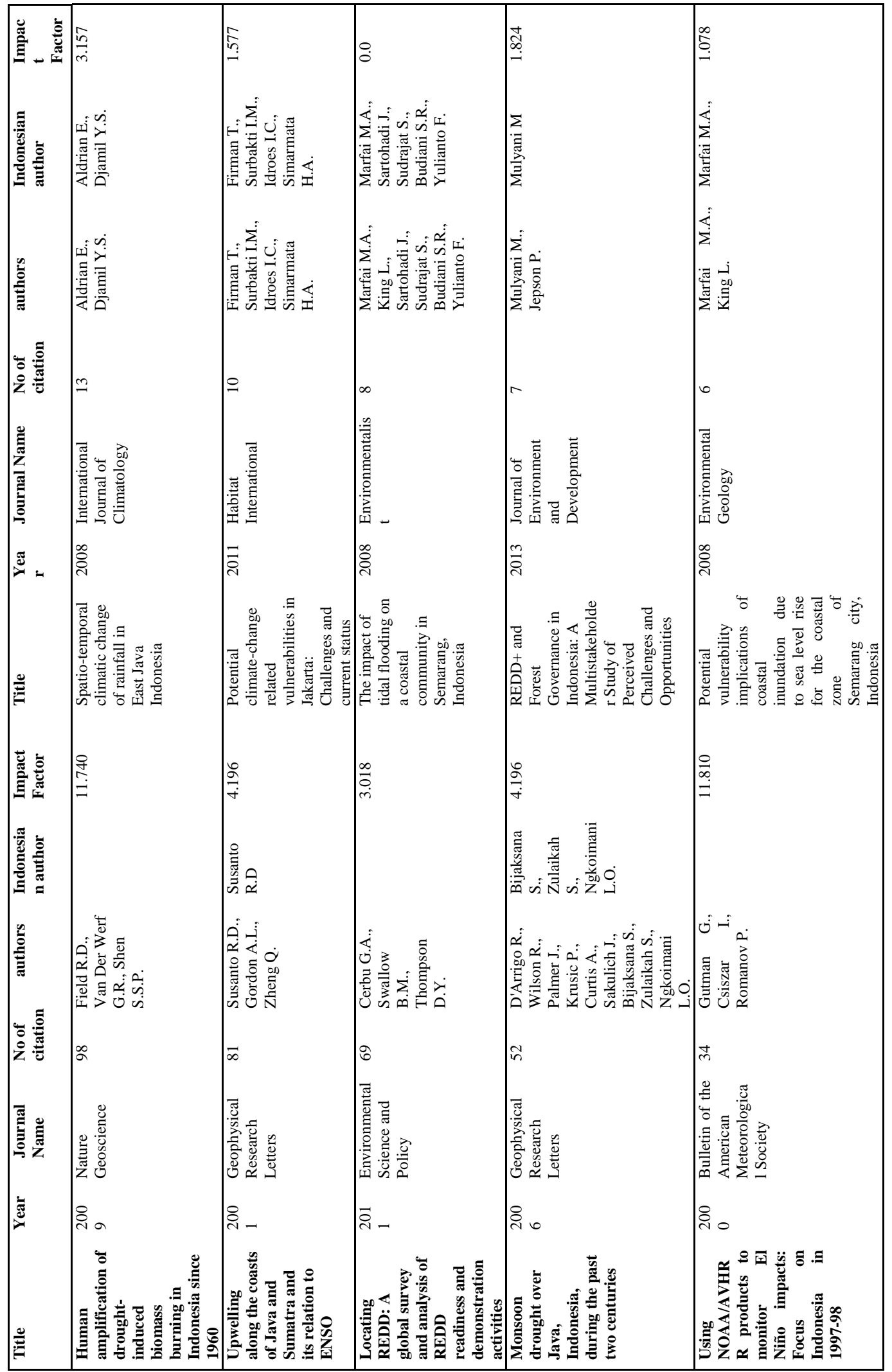

m 
Nat. Hazards Earth Syst. Sci. Discuss., doi:10.5194/nhess-2016-112, 2016 Manuscript under review for journal Nat. Hazards Earth Syst. Sci.

Published: 11 May 2016

(c) Author(s) 2016. CC-BY 3.0 License.

\section{(c) (i)}

Natural Hazards 웅 and Earth System Sciences

Discussions

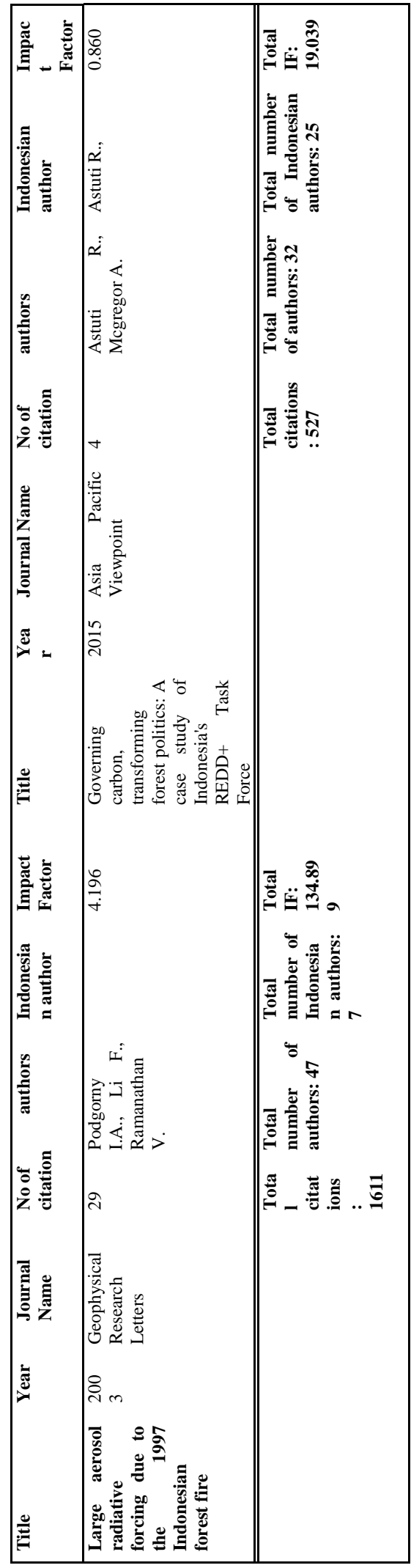


Nat. Hazards Earth Syst. Sci. Discuss., doi:10.5194/nhess-2016-112, 2016

Manuscript under review for journal Nat. Hazards Earth Syst. Sci.

Published: 11 May 2016

(c) Author(s) 2016. CC-BY 3.0 License.

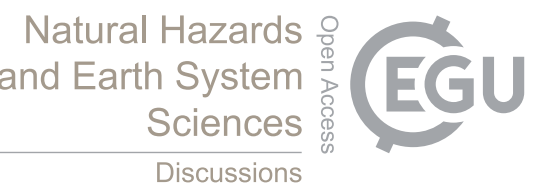

\section{Conclusions and recommendations for future research needs}

This paper has outlined an overview of current research trends and progress related to hazards, disasters, and disaster risks reduction, as well as increasingly on climate change impacts and governance in Indonesia. The first recommendation is that future research agendas also need to focus on different hazards, different locations in Indonesia, and other topics in DRR and climate change. It has been shown in this paper that the research have focused mainly on the geophysical hazards and those related to hydro-meteorological hazards only receive attention recently. Assessments of multi- hazards that combined risks and the associated impacts from geophysical and hydro-meteorological hazards simultaneously are suggested.

It has been seen that majority of research focus on the Islands of Java and Sumatera. There is still greater need for research on climate change topics related to vulnerability, adaptation limits, loss and damage, impacts on key sectors such as fisheries, coastal communities, food security and health. There needs to be more research on other part of Indonesian. The impacts of sea level rise on small islands, drought on forest in Kalimantan and Papua, increase sea water and ocean acidification on fisheries industry in Sulawesi and eastern part of Indonesia, are some of the increasingly worrisome expected from climate change. More research is needed on the context of urban areas by which social risks and risks from natural hazards play out simultaneously, and the impacts on the urban dwellers are to be understood. The governance of DRR has not received many researches especially on the interplay with decentralization which put responsibility for disaster risk management and reduction at the local government level. Many activities done by international and development agencies have focused on the community level. There is abundance of activities reports by donor and international agencies, however, those reports rarely be made available or submitted for academic publications.

The second recommendation is on the need to strengthen the capacity of research collaborations between Indonesian and international researchers, multi-disciplinarity of research and publications for high impacts journals. It is clear that some of the very limited Indonesian researchers from ITB, LIPI, and UGM have been involved in international collaborations and in publications of high impacts journal. There is abundance of materials within Indonesian repositories related to bencana (disaster in English), especially within the repositories with ITB, UGM, and UNSYIAH. These materials and research activities done within the universities needed to be reviewed and submitted for international journals in order to give a broader view on issues that have been discussed by scholars in Indonesia. There is only 1 Indonesian journal that made to the list.

There is a need for better target of scholars to do more collaboration for research and writing for high impact journals. It is also not clear how collaborations amongst scientists from social and physical scientist have taken place in Indonesia. There is still small numbers of female and of early career researchers. Moreover, the roles of universities and researchers from outside Java had been very limited in their progress. There is increasing call for a more inter-disciplinarily collaborations so that complex problems on the social and environmental issues can be understood better and problems identifications can target those in needs better. It is also not clear how or whether science and policy collaborations have taken place and be documented in these listed publications. Although we can see from the list that some of the most prominent authors are not only from universities but also from national level government agencies. The roles of private business and the communities at risk have rarely been part of the research and collaborations.

In conclusion this study has been able to determine the progress in research related to hazards, risks, and risk deduction and climate change in Indonesia. It has also been able to examine the roles of Indonesian scientist in collaborations and towards high quality publications. The recommendations are outlined toward these two issues and it is the responsibility both by the 
Nat. Hazards Earth Syst. Sci. Discuss., doi:10.5194/nhess-2016-112, 2016

Manuscript under review for journal Nat. Hazards Earth Syst. Sci.

Published: 11 May 2016

(c) Author(s) 2016. CC-BY 3.0 License.
Natural Hazards

and Earth System

Sciences

Discussions

Indonesian and international organizations that have and going to work in Indonesia to be able to meet the needs in order for

Appendix

Appendix 1 List of Indonesian authors with publications more than 1

\begin{tabular}{|c|c|c|c|c|c|c|c|c|}
\hline \multirow{2}{*}{$\begin{array}{l}\text { Indonesian } \\
\text { Author }\end{array}$} & \multirow{2}{*}{$\begin{array}{l}\text { No. of } \\
\text { public } \\
\text { ations } \\
\text { in this } \\
\text { review }\end{array}$} & \multirow[t]{2}{*}{ Org. } & \multicolumn{2}{|c|}{ Location } & \multicolumn{2}{|c|}{$\begin{array}{l}\text { Gende } \\
\mathbf{r}\end{array}$} & \multirow{2}{*}{$\begin{array}{l}\text { SCOPUS profile } \\
\text { citations, h-index, co-authors, most } \\
\text { frequent collaborator) }\end{array}$} & \multirow{2}{*}{$\begin{array}{l}\text { Google Scholar } \\
\text { profile } \\
\text { (publications, } \\
\text { citations, h- } \\
\text { index,i-10 index) }\end{array}$} \\
\hline & & & $\mathrm{J} \quad \mathrm{OJ}$ & $\mathrm{N} \quad \mathrm{I}$ & M & $\mathrm{F}$ & & \\
\hline Surono, & 18 & PVMBG & & $\mathrm{x}$ & $\mathrm{x}$ & & $27,348,12,125$, Hendrasto $M$ & NA \\
\hline Abidin, H.Z. & 16 & ITB & $\bar{X}$ & & $\mathrm{x}$ & & $53,493,11,121$, Andreas $\mathrm{H}$ & NA \\
\hline $\begin{array}{l}\text { Natawidjaja, } \\
\text { D.H. }\end{array}$ & 11 & LIPI & & $\mathrm{x}$ & $\mathrm{x}$ & & $42,1913,21,123$, Sieh KE & $147,2964,25,33$ \\
\hline Marfai, M.A. & 11 & UGM & $\mathrm{x}$ & & $\mathrm{x}$ & & 19, 183, 8, 36, King, Lorenz & $79,517,12,14$ \\
\hline Hendrasto $M$ & 10 & PVMBG & & $\mathrm{x}$ & $\mathrm{x}$ & & $16,92,4$, Surono & NA \\
\hline Andreas, $\mathrm{H}$. & 10 & ITB & $\mathrm{x}$ & & $\mathrm{x}$ & & $20,123,6,46$, Abidin, $\mathrm{HZ}$ & NA \\
\hline $\begin{array}{l}\text { Ratdomopurbo, } \\
\text { A. }\end{array}$ & 8 & NTU & & $\mathrm{x}$ & $\mathrm{x}$ & & 17, 441, 10, 59, Lühr, B G & NA \\
\hline Muhari, A. & 8 & MAAF & & $\mathrm{x}$ & $\mathrm{x}$ & & $15,112,6,53$, Imamura, F & NA \\
\hline Sumarti, Sri. & 8 & UGM & $\mathrm{x}$ & & & $\mathrm{x}$ & $14,367,13,84$, Surono & NA \\
\hline Suwargadi, BW & 7 & LIPI & & $\mathrm{x}$ & $\mathrm{x}$ & & $31,1102,17,103$, Natawidjaja, DH & $97,1585,20,24$ \\
\hline Meilano, Irwan & 7 & ITB & $\mathrm{x}$ & & $\mathrm{x}$ & & $32,249,8,115$, Fumiaki & $95,357,9,9$ \\
\hline Setiadi, $\mathbf{N}$. & 7 & $\begin{array}{l}\text { Formerly } \\
\text { UNU- } \\
\text { EHS, } \\
\text { Germany }\end{array}$ & & $\bar{x}$ & & $\mathrm{x}$ & $9,105,4,4,47$, Birkmann, J & NA \\
\hline Djalante, $R$. & 6 & $\begin{array}{l}\text { UNU- } \\
\text { EHS, } \\
\text { Germany }\end{array}$ & & $\bar{x}$ & & $\mathrm{x}$ & $7,56,4,40$, Thomalla, F & $20,146,6,6$ \\
\hline Andreastuti, $\mathrm{S}$ & 6 & PVBMG & & $\bar{x}$ & & $\mathrm{x}$ & $6,256,6,39$, del Marmol, M A & NA \\
\hline Bronto, S. & 6 & PVBMG & & $\mathrm{x}$ & $\mathrm{x}$ & & & NA \\
\hline $\begin{array}{l}\text { Purbawinata M. } \\
\text { A. }\end{array}$ & 6 & PVBMG & & $\mathrm{x}$ & $\mathrm{x}$ & & $8 ; 114 ; 5 ; 56 ;$ Hendrasto, $\mathrm{M}$ & NA \\
\hline Fathani, T.F. & 5 & UGM & $\mathrm{x}$ & & $\mathrm{x}$ & & 11;9;1;26;Karnawati D & NA \\
\hline Kirono, D.G.C. & 5 & $\begin{array}{l}\text { CSIRO } \\
\text { (Australi } \\
\text { a) } \\
\end{array}$ & & $\mathrm{x}$ & & $\mathrm{x}$ & $25,399,9,65$, Kent DM & NA \\
\hline Gumilar I & 5 & ITB & $\mathrm{x}$ & & $\mathrm{x}$ & & $12,46,3,28$, Zainal HA & NA \\
\hline Gamal, M & 5 & ITB & $\mathrm{x}$ & & $\mathrm{x}$ & & 11,41,3,37, Zainal HA & NA \\
\hline Hadmoko, D.S. & 5 & UGM & $\mathrm{x}$ & & $\mathrm{x}$ & & $11,84,5,55$, Lavigne $\mathrm{F}$ & NA \\
\hline Harjono, $\mathrm{H}$. & 5 & LIPI & & $\mathrm{x}$ & $\mathrm{x}$ & & 13,143,8,40,Diament M & NA \\
\hline Prasetya, G. & 5 & TRC & & $\mathrm{x}$ & $\mathrm{x}$ & & $17,230,7,57$, De Lange, $\mathrm{W} P$ & NA \\
\hline Syamsidik, & 5 & $\begin{array}{l}\text { UNSYIA } \\
\mathrm{H}\end{array}$ & $\mathrm{x}$ & & $\mathrm{x}$ & & $8,8,1,15$, Aoki S & $23 ; 32 ; 4 ; 1$ \\
\hline Habibi, P & 4 & UNRAM & $\mathrm{x}$ & & $\mathrm{x}$ & & $4,9,1,27$, Butler JR & NA \\
\hline Hananto, N.D. & 4 & LIPI & & $\mathrm{x}$ & $\mathrm{x}$ & & $13,354,9,56$, Singh $S$ & $53 ; 520 ; 10 ; 10$ \\
\hline Handayani T & 4 & UNRAM & $\mathrm{x}$ & & & $\mathrm{x}$ & $4,9,1,27$, Butler JR & NA \\
\hline Latief, $\mathrm{H}$. & 4 & ITB & $\mathrm{x}$ & & $\mathrm{x}$ & & $1,0,0,5$, Asrurifak M & NA \\
\hline Triatmadja, $\mathbf{R}$. & 4 & UGM & $\mathrm{x}$ & & $\mathrm{x}$ & & $5,6,1,5$, Benazir & $57 ; 50 ; 4 ; 2$ \\
\hline Irsyam, $M$. & 4 & ITB & $\mathrm{x}$ & & $\mathrm{x}$ & & $20,63,4,75$,Hryciw RD & NA \\
\hline
\end{tabular}


Nat. Hazards Earth Syst. Sci. Discuss., doi:10.5194/nhess-2016-112, 2016

Manuscript under review for journal Nat. Hazards Earth Syst. Sci.

Published: 11 May 2016

(c) Author(s) 2016. CC-BY 3.0 License.
Natural Hazards

and Earth System

Sciences

Discussions

\begin{tabular}{|c|c|c|c|c|c|c|c|c|}
\hline Kongko, W. & 3 & BPPT & & $\mathrm{x}$ & $\mathrm{x}$ & & 12,269,5,69,McAdoo BG & $35 ; 422 ; 7 ; 5$ \\
\hline Subandriyo D A & 3 & BPPTKG & & $\mathrm{x}$ & $\mathrm{x}$ & & $2,15,1,17$,Agung Nandaka IM & NA \\
\hline Harjadi, $\mathbf{P .}$ & 3 & BMKG & & $\mathrm{x}$ & $\mathrm{x}$ & & $10,138,7,45$, Yamashina $\mathrm{T}$ & NA \\
\hline Purnomo, H. & 3 & IPB & $\mathrm{x}$ & & $\mathrm{x}$ & & 19,151,7,31,Irawati RH & $377 ; 563 ; 12 ; 14$ \\
\hline Yulianto, F. & 3 & LAPAN & & $\mathrm{x}$ & $\mathrm{x}$ & & $6,38,3,17$, Komarudin MR & NA \\
\hline Karnawati, D. & 3 & UGM & $\mathrm{x}$ & & & $\mathrm{x}$ & 11;36;3;26;Fathani, T F & NA \\
\hline Pribadi, K.S. & 3 & ITB & $\mathrm{x}$ & & $\mathrm{x}$ & & $\begin{array}{l}9,12,2,26, \text { Soekiman/Sumardi,Wirahadik } \\
\text { usumah }\end{array}$ & NA \\
\hline Djaja R & 3 & $\begin{array}{l}\text { Bakosurt } \\
\text { anal }\end{array}$ & & $\mathrm{x}$ & $\mathrm{x}$ & & 3,95,3,14,Abidin HZ & NA \\
\hline Mulyasari, F. & 3 & ITB & $\mathrm{x}$ & & & $\mathrm{x}$ & $7,10,2$, Shaw $\mathrm{R}$ & NA \\
\hline Suadnya W & 3 & UNRAM & $\bar{x}$ & & $\mathrm{x}$ & & $5,9,1,33$, Butler JR & NA \\
\hline Yanuartati, Y & 3 & UNRAM & $\mathrm{x}$ & & & $\mathrm{x}$ & 3,9,1,23,Bohensky EL & NA \\
\hline Darmawan D & 3 & $\begin{array}{l}\text { Telkom } \\
\text { Uni }\end{array}$ & $\mathrm{x}$ & & $\mathrm{x}$ & & 6,92,3,23,Abidin HZ & NA \\
\hline Murdiyarso, D. & 3 & IPB & $\mathrm{x}$ & & $\bar{x}$ & & $57,2797,23,>150$, Verchot LV & $308 ; 6857 ; 39 ; 72$ \\
\hline Susanto, R.D. & 2 & $\begin{array}{l}\text { Universit } \\
\text { y } \\
\text { Marylan } \\
\text { d (USA) }\end{array}$ & & $\bar{x}$ & $\mathrm{x}$ & & $23,837,15,38$,Gordon AL & $55 ; 1826 ; 20 ; 26$ \\
\hline Firman, $T$ & 2 & ITB & $\mathrm{x}$ & & $\mathrm{x}$ & & $8,21,2,5$, Hudalah D & $70 ; 1264 ; 23 ; 28$ \\
\hline Sagala, S & 2 & ITB & $\mathrm{x}$ & & $\mathrm{x}$ & & $5,25,2,12$, Okada $\mathrm{N}$ & $\begin{array}{l}17 \text { publications } \\
34 \text { citations } \\
1.45 \text { impact points }\end{array}$ \\
\hline Lassa, JA & 2 & NTU & & $\bar{x}$ & $\mathrm{x}$ & & 6,0,0,9,Caballero-A M & $\begin{array}{l}\text { https://www.rsis.ed } \\
\text { u.sg/profile/jonatan } \\
\text {-anderias- } \\
\text { lassa/\#.VsrWBPnh } \\
\text { C70 }\end{array}$ \\
\hline Andayani, B. & 2 & UGM & $\bar{x}$ & & & $\mathrm{x}$ & $5,8,1,9$, Fathani TF & $30 ; 91 ; 6 ; 2$ \\
\hline $\begin{array}{l}\text { Siswowidjoyo } \\
\text { S., } \\
\end{array}$ & 2 & PVMBG & & $\mathrm{x}$ & $\mathrm{x}$ & & 3,170,3,7,Constantine EK & NA \\
\hline Aldrian, E & 2 & BMKG & & $\mathrm{x}$ & $\mathrm{x}$ & & 13,268,8,46,Podzun R & $62 ; 1099 ; 11 ; 15$ \\
\hline $\begin{array}{l}\text { Prawirodirdjo, } \\
\text { L }\end{array}$ & & $\begin{array}{l}\text { UC San } \\
\text { Diego }\end{array}$ & & $\mathrm{x}$ & & $\mathrm{x}$ & $18,1799,16,59$, Bock Y & NA \\
\hline Amien, I & 2 & IPB & $\mathrm{x}$ & & $\mathrm{x}$ & & 2,36,6,Estinintyas $\mathrm{W}$ & NA \\
\hline $\begin{array}{l}\text { Redjekiningru } \\
\mathbf{m}, \mathbf{P}\end{array}$ & 2 & IPB & $\bar{X}$ & & & $\mathrm{x}$ & $1,14,1,3$,Amien I & NA \\
\hline Sudibyakto & 2 & UGM & $\mathrm{x}$ & & $\mathrm{x}$ & & 3,0,0,2,Abasi/Haroonah & NA \\
\hline
\end{tabular}

\section{Reference}

590 Abidin, H.Z., Andreas, H., Gumilar, I., Fukuda, Y., Pohan, Y.E., Deguchi, T. (2011) Land subsidence of Jakarta (Indonesia) and its relation with urban development. Natural Hazards 59, 1753-1771.

Adiyoso, W., Kanegae, H. (2013) Effectiveness of disaster-based school program on students' earthquake-preparedness. Journal of Disaster Research 8, 1009-1017.

Aldrian, E., Djamil, Y.S. (2008) Spatio-temporal climatic change of rainfall in East Java Indonesia. International Journal of Climatology 28, 435-448

Aldrian, E., Dwi Susanto, R. (2003) Identification of three dominant rainfall regions within Indonesia and their relationship to sea surface temperature. International Journal of Climatology 23, 1435-1452. 
Nat. Hazards Earth Syst. Sci. Discuss., doi:10.5194/nhess-2016-112, 2016

Manuscript under review for journal Nat. Hazards Earth Syst. Sci.

Published: 11 May 2016

(c) Author(s) 2016. CC-BY 3.0 License.

Aleotti, P., Chowdhury, R. (1999) Landslide hazard assessment: Summary review and new perspectives. Bulletin of Engineering Geology and the Environment 58, 21-44.

Amien, I., Redjekiningrum, P., Kartiwa, B., Estiningtyas, W. (1999) Simulated rice yields as affected by interannual climate variability and possible climate change in Java. Climate Research 12, 145-152.

Amien, I., Rejekiningrum, P., Pramudia, A., Susanti, E. (1996) Effects of evterajnnual climate variability and climate change on rice yield in Java, Indonesia. Water, Air, and Soil Pollution 92, 29-39.

Andreastuti, S.D., Alloway, B.V., Smith, I.E.M. (2000) A detailed tephrostratigraphic framework at Merapi Volcano,

Central Java, Indonesia: Implications for eruption predictions and hazard assessment. Journal of Volcanology and Geothermal Research 100, 51-67.

Bakkalbasi, N., Bauer, K., Glover, J., Wang, L. (2006) Three options for citation tracking: Google Scholar, Scopus and Web of Science. Biomedical Digital Libraries 3.

Bakkour, D., Enjolras, G., Thouret, J.C., Kast, R., Mei, E.T.W., Prihatminingtyas, B. (2015) The adaptive governance of

610 natural disaster systems: Insights from the 2010 mount Merapi eruption in Indonesia. International Journal of Disaster Risk Reduction 13, 167-188.

Balgos, B., Gaillard, J.C., Sanz, K. (2012) The warias of Indonesia in disaster risk reduction: the case of the 2010 Mt Merapi eruption in Indonesia. Gender and Development 20,337-348.

Bar-Ilan, J. (2008) Which h-index? - A comparison of WoS, Scopus and Google Scholar. Scientometrics 74, 257-271.

615 Baumann, P.R. (2008) Tsunami 2004: The villages of Birek and Seungko Mulat, Indonesia. Geocarto International 23, 327 335.

Berrang-Ford, L., Ford, J.D., Lesnikowski, A., Poutiainen, C., Barrera, M., Heymann, S.J. (2014) What drives national adaptation? A global assessment. Climatic Change 124, 441-450.

Berrang-Ford, L., Ford, J.D., Paterson, J. (2011) Are we adapting to climate change? Global Environmental Change 21, 25 62033

Berrang-Ford, L., Pearce, T., Ford, J.D. (2015) Systematic review approaches for climate change adaptation research. Regional Environmental Change 15, 755-769.

Birkmann, J., Buckle, P., Jaeger, J., Pelling, M., Setiadi, N., Garschagen, M., Fernando, N., Kropp, J. (2010) Extreme events and disasters: A window of opportunity for change? Analysis of organizational, institutional and political changes, formal and informal responses after mega-disasters. Natural Hazards 55, 637-655.

Birkmann, J., Setiadi, N., Fiedler, G., (2015) A culture of resilience and preparedness: The 'last mile' case study of tsunami risk in Padang, Indonesia, Cultures and Disasters: Understanding Cultural Framings in Disaster Risk Reduction, pp. 235254.

Brauer, M., Hisham-Hashim, J. (1998) Fires in Indonesia: Crisis and reaction. Environmental Science and Technology 32, 404A-407A.

Briggs, R.W., Sieh, K., Meltzner, A.J., Natawidjaja, D., Galetzka, J., Suwargadi, B., Hsu, Y.J., Simons, M., Hananto, N., Suprihanto, I., Prayudi, D., Avouac, J.P., Prawirodirdjo, L., Bock, Y. (2006) Deformation and slip along the Sunda megathrust in the great 2005 Nias-Simeulue earthquake. Science 311, 1897-1901.

Brink, E., Aalders, T., Ádám, D., Feller, R., Henselek, Y., Hoffmann, A., Ibe, K., Matthey-Doret, A., Meyer, M., Negrut,

N.L., Rau, A.L., Riewerts, B., von Schuckmann, L., Törnros, S., von Wehrden, H., Abson, D.J., Wamsler, C. (2016) Cascades of green: A review of ecosystem-based adaptation in urban areas. Global Environmental Change 36, 111-123.

Burnham, J.F. (2006) Scopus database: A review. Biomedical Digital Libraries 3.

Carn, S.A. (1999) Application of synthetic aperture radar (SAR) imagery to volcano mapping in the humid tropics: A case study in East Java, Indonesia. Bulletin of Volcanology 61, 92-105. 
Nat. Hazards Earth Syst. Sci. Discuss., doi:10.5194/nhess-2016-112, 2016

Manuscript under review for journal Nat. Hazards Earth Syst. Sci.

Published: 11 May 2016

(c) Author(s) 2016. CC-BY 3.0 License.

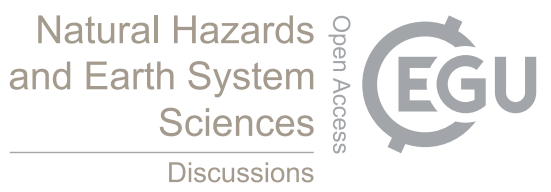

640 Carrion, C., Levinson, D. (2012) Value of travel time reliability: A review of current evidence. Transportation Research Part A: Policy and Practice 46, 720-741.

Caruso, R., Petrarca, I., Ricciuti, R. (2016) Climate change, rice crops, and violence: Evidence from Indonesia. Journal of Peace Research 53, 66-83.

Chai, J., Liu, J.N.K., Ngai, E.W.T. (2013) Application of decision-making techniques in supplier selection: A systematic review of literature. Expert Systems with Applications 40, 3872-3885.

Chang Seng, D.S. (2013) Tsunami resilience: Multi-level institutional arrangements, architectures and system of governance for disaster risk preparedness in Indonesia. Environmental Science and Policy 29, 57-70.

Chang, Y., Wilkinson, S., Potangaroa, R., Seville, E. (2011) Donor-driven resource procurement for post-disaster reconstruction: Constraints and actions. Habitat International 35, 199-205.

650 Charbonnier, S.J., Gertisser, R. (2008) Field observations and surface characteristics of pristine block-and-ash flow deposits from the 2006 eruption of Merapi Volcano, Java, Indonesia. Journal of Volcanology and Geothermal Research 177, 971-982. Chrastansky, A., Rotstayn, L.D. (2012) The effect of ENSO-induced rainfall and circulation changes on the direct and indirect radiative forcing from Indonesian biomass-burning aerosols. Atmospheric Chemistry and Physics 12, 11395-11416. Coughlan de Perez, E., Nerlander, L., Monasso, F., van Aalst, M., Mantilla, G., Muli, E., Nguyen, T., Rose, G., Rumbaitis Del Rio, C. (2015) Managing health risks in a changing climate: Red Cross operations in East Africa and Southeast Asia. Climate and Development 7, 197-207.

D'Arrigo, R., Abram, N., Ummenhofer, C., Palmer, J., Mudelsee, M. (2011) Reconstructed streamflow for Citarum River, Java, Indonesia: Linkages to tropical climate dynamics. Climate Dynamics 36, 451-462.

D'Arrigo, R., Smerdon, J.E. (2008) Tropical climate influences on drought variability over Java, Indonesia. Geophysical 660 Research Letters 35.

D'Arrigo, R., Wilson, R. (2008) El Niño and Indian Ocean influences on Indonesian drought: Implications for forecasting rainfall and crop productivity. International Journal of Climatology 28, 611-616.

D'Arrigo, R., Wilson, R., Palmer, J., Krusic, P., Curtis, A., Sakulich, J., Bijaksana, S., Zulaikah, S., Ngkoimani, L.O. (2006) Monsoon drought over Java, Indonesia, during the past two centuries. Geophysical Research Letters 33.

665 Daly, P., Brassard, C. (2011) Aid accountability and participatory approaches in post-disaster housing reconstruction1. Asian Journal of Social Science 39, 508-533.

De Moya-Anegón, F., Chinchilla-Rodríguez, Z., Vargas-Quesada, B., Corera-Álvarez, E., Muñoz-Fernández, F.J., GonzálezMolina, A., Herrero-Solana, V. (2007) Coverage analysis of Scopus: A journal metric approach. Scientometrics 73, 53-78.

Dicky, M., Haerani, E., Shibayama, M., Ueshima, M., Kagawa, N., Hirnawan, F., (2015) Disaster awareness education for 670 children in schools around geological hazard prone areas in Indonesia, Engineering Geology for Society and Territory Volume 6: Applied Geology for Major Engineering Projects, pp. 107-111.

DIKTI, (2016a) Indonesian Scientific Journal Database.

DIKTI, (2016b) List of Indonesian Journals indexed in SCOPUS.

Djalante, R., Holley, C., Thomalla, F., Carnegie, M. (2013) Pathways for adaptive and integrated disaster resilience. Natural Hazards 69, 2105-2135.

Djalante, R., Thomalla, F. (2012) Disaster risk reduction and climate change adaptation in Indonesia: Institutional challenges and opportunities for integration. International Journal of Disaster Resilience in the Built Environment 3, 166-180.

Djalante, R., Thomalla, F., Sinapoy, M.S., Carnegie, M. (2012) Building resilience to natural hazards in Indonesia: Progress and challenges in implementing the Hyogo Framework for Action. Natural Hazards 62, 779-803.

680 Donovan, K. (2010) Doing social volcanology: Exploring volcanic culture in Indonesia. Area 42, 117-126.

Donovan, K., Suryanto, A., Utami, P. (2012) Mapping cultural vulnerability in volcanic regions: The practical application of social volcanology at Mt Merapi, Indonesia. Environmental Hazards 11, 303-323. 
Nat. Hazards Earth Syst. Sci. Discuss., doi:10.5194/nhess-2016-112, 2016

Manuscript under review for journal Nat. Hazards Earth Syst. Sci.

Published: 11 May 2016

(c) Author(s) 2016. CC-BY 3.0 License.

Du, Y.B., Lee, C.T., Christina, D., Belfer, M.L., Betancourt, T.S., O'Rourke, E.J., Palfrey, J.S. (2012) The living environment and children's fears following the Indonesian tsunami. Disasters 36, 495-513.

EMDAT, (2016) Disaster Profile: Indonesia.

Enia, J.S. (2008) Peace in its Wake? The 2004 Tsunami and internal conflict in Indonesia and Sri Lanka. Journal of Public and International Affairs 19, 7-27.

EOS, (2016) Kerry Sieh.

Esteban, M., Tsimopoulou, V., Mikami, T., Yun, N.Y., Suppasri, A., Shibayama, T. (2013) Recent tsunamis events and preparedness: Development of tsunami awareness in Indonesia, Chile and Japan. International Journal of Disaster Risk Reduction 5, 84-97.

Falagas, M.E., Pitsouni, E.I., Malietzis, G.A., Pappas, G. (2008) Comparison of PubMed, Scopus, Web of Science, and Google Scholar: Strengths and weaknesses. FASEB Journal 22, 338-342.

Fang, M., Huang, W. (1998) Tracking the Indonesian forest fire using NOAA/AVHRR images. International Journal of Remote Sensing 19, 387-390.

Ford, J.D., Berrang-Ford, L., Biesbroek, R., Araos, M., Austin, S.E., Lesnikowski, A. (2015a) Adaptation tracking for a post-2015 climate agreement. Nature Climate Change 5, 967-969.

Ford, J.D., Berrang-Ford, L., Bunce, A., McKay, C., Irwin, M., Pearce, T. (2015b) The status of climate change adaptation in Africa and Asia. Regional Environmental Change 15, 801-814.

700 Ford, J.D., Berrang-Ford, L., Lesnikowski, A., Barrera, M., Jody Heymann, S. (2013) How to track adaptation to climate change: A typology of approaches for national-level application. Ecology and Society 18.

Ford, J.D., Berrang-Ford, L., Paterson, J. (2011) A systematic review of observed climate change adaptation in developed nations. Climatic Change 106, 327-336.

Ford, J.D., Vanderbilt, W., Berrang-Ford, L. (2012) Authorship in IPCC AR5 and its implications for content: Climate

change and Indigenous populations in WGII. Climatic Change 113, 201-213.

Gaillard, J.C., Clavé, E., Kelman, I. (2008a) Wave of peace? Tsunami disaster diplomacy in Aceh, Indonesia. Geoforum 39, 511-526.

Gaillard, J.C., Clavé, E., Vibert, O., Azhari, D., Denain, J.C., Efendi, Y., Grancher, D., Liamzon, C.C., Sari, D.R., Setiawan, R. (2008b) Ethnic groups' response to the 26 December 2004 earthquake and tsunami in Aceh, Indonesia. Natural Hazards $710 \quad 47,17-38$.

Gate, R., (2016) Research Gate.

Gertisser, R., Cassidy, N.J., Charbonnier, S.J., Nuzzo, L., Preece, K. (2012) Overbank block-and-ash flow deposits and the impact of valley-derived, unconfined flows on populated areas at Merapi volcano, Java, Indonesia. Natural Hazards 60, 623648.

715 Godavitarne, C., Udu-Gama, N., Sreetharan, M., Preuss, J., Krimgold, F. (2006) Social and political prerequisites for recovery in Sri Lanka after the December 2004 Indian Ocean tsunami. Earthquake Spectra 22, S845-S861.

Google, (2016) Goggle Scholar.

Google Scholar, (2016a) Aris Marfai.

Google Scholar, (2016b) Barry Voight.

720 Google Scholar, (2016c) Danny Hilman Natawidjaja.

Google Scholar, (2016d) Frank Lavigne.

Google Scholar, (2016e) Hasanuddin Z. Abidin.

Google Scholar, (2016f) Ralf Gertisser.

Gosling, J., Naim, M.M. (2009) Engineer-to-order supply chain management: A literature review and research agenda. 
Nat. Hazards Earth Syst. Sci. Discuss., doi:10.5194/nhess-2016-112, 2016

Manuscript under review for journal Nat. Hazards Earth Syst. Sci.

Published: 11 May 2016

(c) Author(s) 2016. CC-BY 3.0 License.

Guarnacci, F.A.U., Di Girolamo, S.B.A., (2012) Risk, altruism and resilience in post-tsunami Indonesia: A gendered perspective, Proceedings of the 4th International Disaster and Risk Conference: Integrative Risk Management in a Changing World - Pathways to a Resilient Society, IDRC Davos 2012, pp. 273-277.

Guarnacci, U. (2012) Governance for sustainable reconstruction after disasters: Lessons from Nias, Indonesia.

Environmental Development 2, 73-85.

Heikens, A., Sumarti, S., Van Bergen, M., Widianarko, B., Fokkert, L., Van Leeuwen, K., Seinen, W. (2005) The impact of the hyperacid Ijen Crater Lake: Risks of excess fluoride to human health. Science of the Total Environment 346, 56-69.

Hidayati, D. (2012) Striving to reduce disaster risk: Vulnerable communities with low levels of preparedness in Indonesia. Journal of Disaster Research 7, 75-82.

Hill, E.M., Borrero, J.C., Huang, Z., Qiu, Q., Banerjee, P., Natawidjaja, D.H., Elosegui, P., Fritz, H.M., Suwargadi, B.W., Pranantyo, I.R., Li, L., Macpherson, K.A., Skanavis, V., Synolakis, C.E., Sieh, K. (2012) The $2010 \mathrm{M}<\mathrm{inf}>\mathrm{w}</ \mathrm{inf}>7.8$ Mentawai earthquake: Very shallow source of a rare tsunami earthquake determined from tsunami field survey and nearfield GPS data. Journal of Geophysical Research: Solid Earth 117.

Hiwasaki, L., Luna, E., Syamsidik, Marçal, J.A. (2015) Local and indigenous knowledge on climate-related hazards of coastal and small island communities in Southeast Asia. Climatic Change 128, 35-56.

Horspool, N., Pranantyo, I., Griffin, J., Latief, H., Natawidjaja, D.H., Kongko, W., Cipta, A., Bustaman, B., Anugrah, S.D., Thio, H.K. (2014) A probabilistic tsunami hazard assessment for Indonesia. Natural Hazards and Earth System Sciences 14, 3105-3122.

Hsu, Y.J., Simons, M., Avouac, J.P., Galeteka, J., Sieh, K., Chlieh, M., Natawidjaja, D., Prawirodirdjo, L., Bock, Y. (2006) Frictional afterslip following the 2005 Nias-Simeulue earthquake, Sumatra. Science 312, 1921-1926.

Hyndman, J. (2009) Siting conflict and peace in post-tsunami Sri Lanka and Aceh, Indonesia. Norsk Geografisk Tidsskrift 63, 89-96.

Irsyam, M., Dangkua, D.T., Hendriyawan, Hoedajanto, D., Hutapea, B.M., Kertapati, E.K., Boen, T., Petersen, M.D. (2008) Proposed seismic hazard maps of Sumatra and Java islands and microzonation study of Jakarta city, Indonesia. Journal of 750 Earth System Science 117, 865-878.

Ishii, M., Shearer, P.M., Houston, H., Vidale, J.E. (2005) Extent, duration and speed of the 2004 Sumatra-Andaman earthquake imaged by the Hi-Net array. Nature 435, 933-936.

Islam, M.S., Lim, S.H. (2015) When "Nature" strikes: A sociology of climate change and disaster vulnerabilities in Asia. Nature and Culture 10, 57-80.

755 James, E. (2008) Getting ahead of the next disaster: Recent preparedness efforts in Indonesia. Development in Practice 18, 424-429.

Jim, C.Y. (1999) The forest fires in Indonesia 1997-98: Possible causes and pervasive consequences. Geography 84, 251260.

Kabisch, N., Qureshi, S., Haase, D. (2015) Human-environment interactions in urban green spaces - A systematic review of contemporary issues and prospects for future research. Environmental Impact Assessment Review 50, 25-34.

Karan, P.P., Subbiah, S.P. (2011) The Indian Ocean tsunami: The global response to a natural disaster.

Kawanishi, M., Mimura, N. (2015) Assessment of insurance for paddy production: a case study in Indonesia. Climate and Development 7, 257-266.

Keil, A., Teufel, N., Gunawan, D., Leemhuis, C. (2009) Vulnerability of smallholder farmers to ENSO-related drought in Indonesia. Climate Research 38, 155-169.

Keil, A., Zeller, M., Wida, A., Sanim, B., Birner, R. (2008) What determines farmers' resilience towards ENSO-related drought? An empirical assessment in Central Sulawesi, Indonesia. Climatic Change 86, 291-307. 
Nat. Hazards Earth Syst. Sci. Discuss., doi:10.5194/nhess-2016-112, 2016

Manuscript under review for journal Nat. Hazards Earth Syst. Sci.

Published: 11 May 2016

(c) Author(s) 2016. CC-BY 3.0 License.

Kelman, I. (2005) Tsunami diplomacy: Will the 26 December, 2004 bring peace to the affected countries? Sociological Research Online 10.

Kennedy, J., Ashmore, J., Babister, E., Kelman, I. (2008) The meaning of 'build back better': Evidence From post-tsunami Aceh and Sri Lanka. Journal of Contingencies and Crisis Management 16, 24-36.

Khandekar, M.L., Murty, T.S., Scott, D., Baird, W. (2000) The 1997 El Nino, Indonesian Forest fires and the Malaysian Smoke problem: A deadly combination of natural and man-made hazard. Natural Hazards 21, 131-144.

Kitchenham, B., Pearl Brereton, O., Budgen, D., Turner, M., Bailey, J., Linkman, S. (2009) Systematic literature reviews in software engineering - A systematic literature review. Information and Software Technology 51, 7-15.

Konca, A.O., Avouac, J.P., Sladen, A., Meltzner, A.J., Sieh, K., Fang, P., Li, Z., Galetzka, J., Genrich, J., Chlieh, M., Natawidjaja, D.H., Bock, Y., Fielding, E.J., Ji, C., Helmberger, D.V. (2008) Partial rupture of a locked patch of the Sumatra megathrust during the 2007 earthquake sequence. Nature 456, 631-635.

Kulkarni, A.V., Aziz, B., Shams, I., Busse, J.W. (2009) Comparisons of citations in web of science, Scopus, and Google Scholar for articles published in general medical journals. JAMA - Journal of the American Medical Association 302, 10921096.

Kusumasari, B., Alam, Q. (2012) Bridging the gaps: The role of local government capability and the management of a natural disaster in Bantul, Indonesia. Natural Hazards 60, 761-779.

Lavigne, F. (1999) Lahar hazard micro-zonation and risk assessment in Yogyakarta city, Indonesia. GeoJournal 49, 173-183. Lawler, J., Patel, M. (2012) Exploring children's vulnerability to climate change and their role in advancing climate change adaptation in East Asia and the Pacific. Environmental Development 3, 123-136.

Le Billon, P., Waizenegger, A. (2007) Peace in the wake of disaster? Secessionist conflicts and the 2004 Indian Ocean tsunami. Transactions of the Institute of British Geographers 32, 411-427.

Lesnikowski, A.C., Ford, J.D., Berrang-Ford, L., Barrera, M., Berry, P., Henderson, J., Heymann, S.J. (2013a) Nationallevel factors affecting planned, public adaptation to health impacts of climate change. Global Environmental Change 23, 1153-1163.

Lesnikowski, A.C., Ford, J.D., Berrang-Ford, L., Barrera, M., Heymann, J. (2013b) How are we adapting to climate change? A global assessment. Mitigation and Adaptation Strategies for Global Change, 1-17.

Leydesdorff, L., De Moya-Anegón, F., Guerrero-Bote, V.P. (2010) Journal maps on the basis of Scopus data: A comparison with the journal citation reports of the ISI. Journal of the American Society for Information Science and Technology 61, 352-369.

Liang, F., Bennett, C.R., Parsons, R.L., Han, J., Lin, C., (2009) A literature review on behavior of scoured piles under bridges, Contemporary Topics in In Situ Testing, Analysis, and Reliability of Foundations - 2009 International Foundation Congress and Equipment Expo, 186 ed, Orlando, FL, pp. 482-489.

800 LMV, (2016) Thouret Jean-Claude.

Lubis, A.M. (2014) Uplift of kelud volcano prior to the november 2007 eruption as observed by L-band insar. Journal of Engineering and Technological Sciences 46, 245-257.

Luederitz, C., Brink, E., Gralla, F., Hermelingmeier, V., Meyer, M., Niven, L., Panzer, L., Partelow, S., Rau, A.L., Sasaki, R., Abson, D.J., Lang, D.J., Wamsler, C., von Wehrden, H. (2015) A review of urban ecosystem services: Six key challenges

for future research. Ecosystem Services 14, 98-112.

Marfai, M.A., King, L. (2008a) Coastal flood management in Semarang, Indonesia. Environmental Geology 55, 1507-1518.

Marfai, M.A., King, L. (2008b) Potential vulnerability implications of coastal inundation due to sea level rise for the coastal zone of Semarang city, Indonesia. Environmental Geology 54, 1235-1245.

Marfai, M.A., King, L., Sartohadi, J., Sudrajat, S., Budiani, S.R., Yulianto, F. (2008) The impact of tidal flooding on a coastal community in Semarang, Indonesia. Environmentalist 28, 237-248. 
Nat. Hazards Earth Syst. Sci. Discuss., doi:10.5194/nhess-2016-112, 2016

Manuscript under review for journal Nat. Hazards Earth Syst. Sci.

Published: 11 May 2016

(c) Author(s) 2016. CC-BY 3.0 License.

Marfai, M.A., Sekaranom, A.B., Ward, P. (2014) Community responses and adaptation strategies toward flood hazard in Jakarta, Indonesia. Natural Hazards.

Marfai, M.A., Sekaranom, A.B., Ward, P. (2015) Community responses and adaptation strategies toward flood hazard in Jakarta, Indonesia. Natural Hazards 75, 1127-1144.

McLeman, R.A., Dupre, J., Berrang Ford, L., Ford, J., Gajewski, K., Marchildon, G. (2014) What we learned from the Dust Bowl: Lessons in science, policy, and adaptation. Population and Environment 35, 417-440.

Moher, D., Liberati, A., Tetzlaff, J., Altman, D.G., Altman, D., Antes, G., Atkins, D., Barbour, V., Barrowman, N., Berlin, J.A., Clark, J., Clarke, M., Cook, D., D'Amico, R., Deeks, J.J., Devereaux, P.J., Dickersin, K., Egger, M., Ernst, E., Gøtzsche, P.C., Grimshaw, J., Guyatt, G., Higgins, J., Ioannidis, J.P.A., Kleijnen, J., Lang, T., Magrini, N., McNamee, D., Moja, L., Mulrow, C., Napoli, M., Oxman, A., Pham, B., Rennie, D., Sampson, M., Schulz, K.F., Shekelle, P.G., Tovey, D., Tugwell, P. (2009) Preferred reporting items for systematic reviews and meta-analyses: The PRISMA statement. PLoS Medicine 6.

Morwood, M.J., Sutikna, T., Saptomo, E.W., Westaway, K.E., Jatmiko, Awe Due, R., Moore, M.W., Yuniawati, D.Y., Hadi, P., Zhao, J.x., Turney, C.S.M., Fifield, K., Allen, H., Soejono, R.P. (2008) Climate, people and faunal succession on Java, Indonesia: evidence from Song Gupuh. Journal of Archaeological Science 35, 1776-1789.

Muhari, A., Imamura, F., Koshimura, S., Post, J. (2011) Examination of three practical run-up models for assessing tsunami impact on highly populated areas. Natural Hazards and Earth System Science 11, 3107-3123.

Muhari, A., Imamura, F., Natawidjaja, D.H., Diposaptono, S., Latief, H., Post, J., Ismail, F.A. (2010) Tsunami mitigation efforts with pTA in west Sumatra province, Indonesia. Journal of Earthquake and Tsunami 4, 341-368.

830 Muis, S., Güneralp, B., Jongman, B., Aerts, J.C.J.H., Ward, P.J. (2015) Flood risk and adaptation strategies under climate change and urban expansion: A probabilistic analysis using global data. Science of the Total Environment 538, 445-457.

Murdiyarso, D. (1993) Policy options to reduce CO2 release resulting from deforestation and biomass burning in indonesia. Chemosphere 27, 1109-1120.

Nakada, S., Zaennudin, A., Maeno, F., Yoshimoto, M., Hokanishi, N. (2016) Credibility of volcanic ash thicknesses reported by the media and local residents following the 2014 eruption of Kelud volcano, Indonesia. Journal of Disaster Research 11, 53-59.

Nakamura, S. (1978) On statistics of tsunamis in Indonesia. Southeast Asian Studies 16, 664-674.

Nalbant, S.S., Steacy, S., Sieh, K., Natawidjaja, D., McCloskey, J. (2005) Seismology: Earthquake risk on the Sunda trench. Nature 435, 756-757.

840 Naylor, R.L., Falcon, W.P., Rochberg, D., Wada, N. (2001) Using El Niño/Southern Oscillation climate data to predict rice production in Indonesia. Climatic Change 50, 255-265.

Neall, V.E. (1976) Lahars as major geological hazards. Bulletin of the International Association of Engineering Geology 13, 233-240.

Neolaka, A. (2012) Flood disaster risk in Jakarta, Indonesia. WIT Transactions on Ecology and the Environment 159, 107118.

Neolaka, A. (2013) Stakeholder participation in flood control of Ciliwung river, Jakarta, Indonesia. WIT Transactions on Ecology and the Environment 171, 275-285.

Noyes, P.D., McElwee, M.K., Miller, H.D., Clark, B.W., Van Tiem, L.A., Walcott, K.C., Erwin, K.N., Levin, E.D. (2009) The toxicology of climate change: Environmental contaminants in a warming world. Environment International 35, 971-986.

Page, S.E., Siegert, F., Rieley, J.O., Boehm, H.D.V., Jaya, A., Limin, S. (2002) The amount of carbon released from peat and forest fires in Indonesia during 1997. Nature 420, 61-65.

Paterson, J.A., Ford, J.D., Ford, L.B., Lesnikowski, A., Berry, P., Henderson, J., Heymann, J. (2012) Adaptation to climate change in the Ontario public health sector. BMC Public Health 12. 
Nat. Hazards Earth Syst. Sci. Discuss., doi:10.5194/nhess-2016-112, 2016

Manuscript under review for journal Nat. Hazards Earth Syst. Sci.

Published: 11 May 2016

(c) Author(s) 2016. CC-BY 3.0 License.

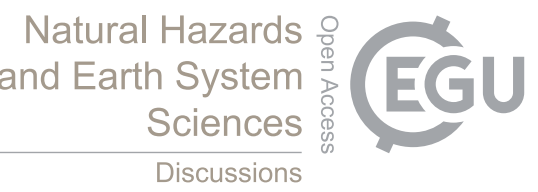

Pearce, T., Ford, J.D., Duerden, F., Smit, B., Andrachuk, M., Berrang-Ford, L., Smith, T. (2011) Advancing adaptation planning for climate change in the Inuvialuit Settlement Region (ISR): A review and critique. Regional Environmental Change 11, 1-17.

Philibosian, B., Sieh, K., Natawidjaja, D.H., Chiang, H.W., Shen, C.C., Suwargadi, B.W., Hill, E.M., Edwards, R.L. (2012) An ancient shallow slip event on the Mentawai segment of the Sunda megathrust, Sumatra. Journal of Geophysical Research: Solid Earth 117.

Prayoedhie, S., Fujii, Y., Shibazaki, B. (2012) Numerical simulations for Tsunami forecasting at Padang city using offshore Tsunami sensors. Bulletin of the International Institute of Seismology and Earthquake Engineering 46, 97-102.

Purnomo, H., Herawati, H., Santoso, H. (2011) Indicators for assessing Indonesia's Javan rhino National Park vulnerability to climate change. Mitigation and Adaptation Strategies for Global Change 16, 733-747.

PVMBG, (2016) Volcanology Survey Indonesia.

Rafliana, I. (2012) Disaster education in Indonesia: Learning how itworks from six years of experience after Indian ocean tsunami in 2004. Journal of Disaster Research 7, 83-91.

Rampino, M.R., Self, S. (1992) Volcanic winter and accelerated glaciation following the Toba super-eruption. Nature 359, 50-52.

Salafsky, N. (1994) Drought in the rain forest: Effects of the 1991 El Niño-Southern Oscillation event on a rural economy in West Kalimantan, Indonesia. Climatic Change 27, 373-396.

Sano, D., Prabhakar, S.V.R.K., Kartikasari, K., Irawan, D.J., (2013) Developing Adaptation Policies in the Agriculture Sector: Indonesia's Experience, Climate Change Adaptation in Practice: From strategy development to implementation, pp. 269-281.

Sarminingsih, A., Soekarno, I., Hadihardaja, I.K., Syahril B.K, M. (2014) Flood vulnerability assessment of Upper Citarum River Basin, West Java, Indonesia. International Journal of Applied Engineering Research 9, 22921-22940.

Schlurmann, T., Kongko, W., Goseberg, N., Natawidjaja, D.H., Sieh, K., (2010) Near-field tsunami hazard map Padang, West Sumatra: Utilizing high resolution geospatial data and reseasonable source scenarios, Proceedings of the Coastal Engineering Conference.

Schlurmann, T., Siebert, M. (2011) The Capacity Building programmes of GITEWS - Visions, goals, lessons learned, and re-iterated needs and demands. Natural Hazards and Earth System Science 11, 293-300.

Shofiyati, R., Takeuchi, W., Sofan, P., Darmawan, S., Awaluddin, Supriatna, W., (2014) Indonesian drought monitoring from space. A report of SAFE activity: Assessment of drought impact on rice production in Indonesia by satellite remote sensing and dissemination with web-GIS, IOP Conference Series: Earth and Environmental Science, 1 ed.

Shrestha, B.B., Okazumi, T., Miyamoto, M., Nabesaka, S., Tanaka, S., Sugiura, A. (2014) Fundamental analysis for flood risk management in the selected river basins of Southeast Asia. Journal of Disaster Research 9, 858-869.

Siagian, T.H., Purhadi, P., Suhartono, S., Ritonga, H. (2014) Social vulnerability to natural hazards in Indonesia: Driving factors and policy implications. Natural Hazards 70, 1603-1617.

Singh, S.C., Hananto, N.D., Chauhan, A.P.S., Permana, H., Denolle, M., Hendriyana, A., Natawidjaja, D. (2010) Evidence of active backthrusting at the NE Margin of Mentawai Islands, SW Sumatra. Geophysical Journal International 180, 703 714.

Siswowidjoyo, S., Sudarsono, U., Wirakusumah, A.D. (1997) The threat of hazards in the Semeru volcano region in East Java, Indonesia. Journal of Asian Earth Sciences 15, 185-194.

SJR, (2016) Scientific Journal Ranking

Solikhin, A., Thouret, J.C., Gupta, A., Harris, A.J.L., Liew, S.C. (2012) Geology, tectonics, and the 2002-2003 eruption of 
Nat. Hazards Earth Syst. Sci. Discuss., doi:10.5194/nhess-2016-112, 2016

Manuscript under review for journal Nat. Hazards Earth Syst. Sci.

Published: 11 May 2016

(c) Author(s) 2016. CC-BY 3.0 License.

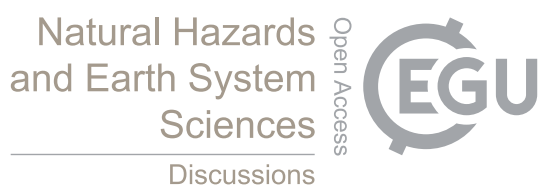

Srinivas, H., Nakagawa, Y. (2008) Environmental implications for disaster preparedness: Lessons Learnt from the Indian Ocean Tsunami. Journal of Environmental Management 89, 4-13.

Steinberg, F. (2007) Housing reconstruction and rehabilitation in Aceh and Nias, Indonesia-Rebuilding lives. Habitat International 31, 150-166.

Steinmetz, T., Raape, U., Teßmann, S., Strobl, C., Friedemann, M., Kukofka, T., Riedlinger, T., Mikusch, E., Dech, S. (2010) Tsunami early warning and decision support. Natural Hazards and Earth System Science 10, 1839-1850.

Stolle, F., Lambin, E.F. (2003) Interprovincial and interannual differences in the causes of land-use fires in Sumatra, Indonesia. Environmental Conservation 30, 375-387.

Stolle, F., Tomich, T.P. (1999) The 1997-1998 fire event in Indonesia. Nature and Resources 35, 22-30.

Sudibyakto (1992) Facts and future trends of climate change: a case study of the eastern part of the Indonesia islands. Indonesian Journal of Geography 23-25, 59-69.

Sudibyakto, Haroonah, N. (1997) Natural disaster mitigation and management in Indonesia. Indonesian Journal of Geography 29, 37-48.

Sudradjat, A., Tilling, R.I. (1984) Volcanic hazards in Indonesia: the 1982-83 eruption of Galunggung. Episodes 7, 13-19.

910 Suryo, I., Clarke, M.C.G. (1985) The occurrence and mitigation of volcanic hazards in Indonesia as exemplified at the Mount Merapi, Mount Kelut and Mount Galunggung volcanoes. Quarterly Journal of Engineering Geology 18, 79-98.

Susanto, R.D., Gordon, A.L., Zheng, Q. (2001) Upwelling along the coasts of Java and Sumatra and its relation to ENSO. Geophysical Research Letters 28, 1599-1602.

Taubenböck, H., Goseberg, N., Setiadi, N., Lämmel, G., Moder, F., Oczipka, M., Klüpfel, H., Wahl, R., Schlurmann, T.,

Strunz, G., Birkmann, J., Nagel, K., Siegert, F., Lehmann, F., Dech, S., Gress, A., Klein, R. (2009) "Last-Mile" preparation for a potential disaster - Interdisciplinary approach towards tsunami early warning and an evacuation information system for the coastal city of Padang, Indonesia. Natural Hazards and Earth System Science 9, 1509-1528.

Tay, S.S.C. (1998) South East Asian forest fires: haze over ASEAN and international environmental law. Review of European Community and International Environmental Law 7, 202-208.

920 Taylor, H., Peace, R. (2015) Children and cultural influences in a natural disaster: Flood response in Surakarta, Indonesia. International Journal of Disaster Risk Reduction 13, 76-84.

Telford, J., Cosgrave, J. (2007) The international humanitarian system and the 2004 Indian Ocean earthquake and tsunamis. Disasters 31, 1-28.

Thomalla, F., Downing, T., Spanger-Siegfried, E., Han, G., Rockström, J. (2006) Reducing hazard vulnerability: Towards a common approach between disaster risk reduction and climate adaptation. Disasters 30, 39-48.

Thompson, H.E., Berrang-Ford, L., Ford, J.D. (2010) Climate change and food security in Sub-Saharan Africa: A systematic literature review. Sustainability 2, 2719-2733.

Thouret, J.C., Lavigne, F., Suwa, H., Sukatja, B., Surono (2007) Volcanic hazards at Mount Semeru, East Java (Indonesia), with emphasis on lahars. Bulletin of Volcanology 70, 221-244.

930 Trunk, L., Bernard, A. (2008) Investigating crater lake warming using ASTER thermal imagery: Case studies at Ruapehu, Poás, Kawah Ijen, and Copahué Volcanoes. Journal of Volcanology and Geothermal Research 178, 259-270.

UGM, (2016) Indonesian Journal of Geography.

Usman, A.B., Hartono (1997) Forest fire monitoring using subresolution dimension of NOAA/AVHRR images in Kalimantan - 1995. Indonesian Journal of Geography 29, 67-77.

935 van Hinsberg, V., Berlo, K., Sumarti, S., van Bergen, M., Williams-Jones, A. (2010) Extreme alteration by hyperacidic brines at Kawah Ijen volcano, East Java, Indonesia: II. Metasomatic imprint and element fluxes. Journal of Volcanology and Geothermal Research 196, 169-184. 
Nat. Hazards Earth Syst. Sci. Discuss., doi:10.5194/nhess-2016-112, 2016

Manuscript under review for journal Nat. Hazards Earth Syst. Sci.

Published: 11 May 2016

(c) Author(s) 2016. CC-BY 3.0 License.

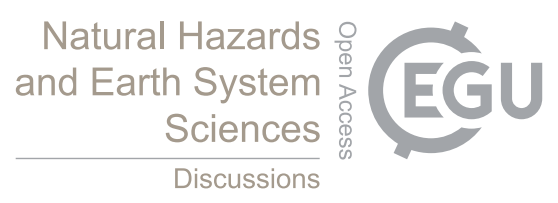

(c) (i)

Verstappen, H.T. (1988) Geomorphological surveys and natural hazard zoning, with special reference to volcanic hazards in central Java. Zeitschrift fur Geomorphologie, Supplementband 68, 81-101.

940 Vignato, S. (2012) Devices of oblivion: How Islamic schools rescue 'orphaned' children from traumatic experiences in Aceh (Indonesia). South East Asia Research 20, 239-261.

Voight, B., Constantine, E.K., Siswowidjoyo, S., Torley, R. (2000) Historical eruptions of Merapi Volcano, Central Java, Indonesia, 1768-1998. Journal of Volcanology and Geothermal Research 100, 69-138.

Widiwijayanti, C., Voight, B., Hidayat, D., Schilling, S.P. (2009) Objective rapid delineation of areas at risk from block-andash pyroclastic flows and surges. Bulletin of Volcanology 71, 687-703.

Woodhouse, C.A., Overpeck, J.T. (1998) 2000 Years of Drought Variability in the Central United States. Bulletin of the American Meteorological Society 79, 2693-2714. 